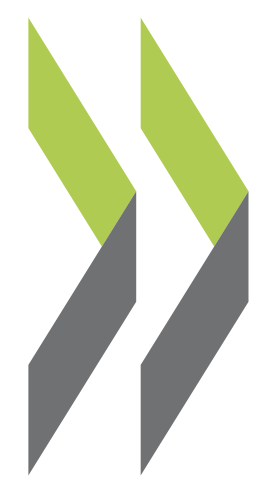

OECD Social, Employment and Migration Working Papers No. 257

Redistribution from a joint income-wealth perspective: Results from 16 European OECD countries

\section{Sarah Kuypers,}

Francesco Figari, Gerlinde Verbist 
For Official Use

English - Or. English

18 January 2021

DIRECTORATE FOR EMPLOYMENT, LABOUR AND SOCIAL AFFAIRS

EMPLOYMENT, LABOUR AND SOCIAL AFFAIRS COMMITTEE

Cancels \& replaces the same document of 15 January 2021

Redistribution from a joint income-wealth perspective

Results from 16 European OECD countries

OECD SOCIAL, EMPLOYMENT AND MIGRATION WORKING PAPERS No. 257.

JEL classifications: D31, H24, I30.

Authorised for publication by Stefano Scarpetta, Director, Directorate for Employment, Labour and Social Affairs.

All Social, Employment and Migration Working Papers are now available through the OECD website at www.oecd.org/els/workingpapers.

Sarah Kuypers, Herman Deleeck Centre for Social Policy, University of Antwerp, Belgium

Francesco Figari, University of Insubria, Italy, CeRP Collegio Carlo Alberto, Italy and ISER, University of Essex, UK

Gerlinde Verbist, Herman Deleeck Centre for Social Policy, University of Antwerp, Belgium

JT03470350 


\title{
OECD Social, Employment and Migration Working Papers
}

\author{
www.oecd.org/els/workingpapers
}

OECD Working Papers should not be reported as representing the official views of the OECD or of its member countries. The opinions expressed and arguments employed are those of the author(s).

Working Papers describe preliminary results or research in progress by the author(s) and are published to stimulate discussion on a broad range of issues on which the OECD works. Comments on Working Papers are welcomed, and may be sent to els.contact@oecd.org.

This series is designed to make available to a wider readership selected labour market, social policy and migration studies prepared for use within the OECD. Authorship is usually collective, but principal writers are named. The papers are generally available only in their original language - English or French - with a summary in the other.

This document and any map included herein are without prejudice to the status of or sovereignty over any territory, to the delimitation of international frontiers and boundaries and to the name of any territory, city or area.

You can copy, download or print OECD content for your own use, and you can include excerpts from OECD publications, databases and multimedia products in your own documents, presentations, blogs, websites and teaching materials, provided that suitable acknowledgment of OECD as source and copyright owner is given. All requests for commercial use and translation rights should be submitted to rights@oecd.org. 


\section{Acknowledgements}

We thank Michael Förster, Sebastian Königs, Rodrigo Fernandez, Olga Rastrigina, Emanuele Ciani , David Bradbury, Pierce O'Reilly and Carlotta Balestra for valuable comments and suggestions. We gratefully acknowledge funding received from the OECD and the Joint Research Centre of the European Commission. The analysis presented in this paper builds on data from the second wave of the Eurosystem Household Finance and Consumption Survey (HFCS) and the EU-wide micro-simulation model EUROMOD. Members of the HFCN and the EUROMOD framework are gratefully acknowledged for their contributions. Results may not correspond to those of the data providers. 


\section{Abstract}

Redistributive analyses typically use household income as the main reference variable to rank households and to assess their tax liabilities and benefit entitlements. However, the importance of wealth, and the potential redistributive effects of wealth-related taxation, are increasingly recognised. By using data from the Household Finance and Consumption Survey (HFCS) as input data for the tax-benefit microsimulation model EUROMOD, we assess the redistributive effects of taxes and benefits against the joint incomewealth distribution for 16 European OECD countries. This is a new approach that extends indicators developed in the asset-based poverty literature. We study wealth-related taxes alongside other tax-benefit instruments. The analysis allows us to gain insight into which types of policies are redistributive in which institutional settings taking account of the distribution of both income and wealth. This paper extends our pilot study of six countries (Kuypers, Figari, \& Verbist, 2019), and updates it to 2017 policies.

\section{Résumé}

Les analyses de la redistribution emploient principalement le revenu des ménage afin de classer les ménages et d'évaluer leurs obligations fiscales et leurs droits aux prestations sociales. Toutefois, le patrimoine, et l'étude des effets redistributifs potentiels sur ce dernier, prennent une importance croissante. À partir du modèle de microsimulation socio-fiscale EUROMOD et des données de l'enquête sur les finances et la consommation des ménages (HFCS), nous évaluons les effets redistributifs qu'exercent les impôts et les prestations sociales sur la distribution conjointe des revenus et des patrimoines dans 16 pays européens de l'OCDE. II s'agit d'une nouvelle approche qui vient s'ajouter aux indicateurs développés dans la littérature sur la pauvreté basée sur les actifs patrimoniaux. Nous nous concentrons conjointement sur les impôts liés au patrimoine, et sur d'autres instruments d'imposition et de prestations sociales. Notre analyse permet de comprendre les effets redistributifs des politiques publiques en fonction leur cadre institutionnel, tout en tenant compte de la répartition conjointe des revenus et du patrimoine. Ce document étend notre étude pilote de six pays (Kuypers, Figari, \& Verbist, 2019), à laquelle nous ajoutons aussi les politiques publiques de 2017. 


\section{Table of contents}

OECD Social, Employment and Migration Working Papers 2

Acknowledgements 3

$\begin{array}{ll}\text { Abstract } & 4\end{array}$

Introduction 6

1. The joint distribution of income and wealth 8

2. Tax-benefit systems and the role of wealth 10

3. Data and methods 24

4. The redistributive effects of tax-benefit systems in from joint income-wealth perspective $\quad 30$

5. The redistributive effects when considering only liquid assets 40

6. The redistributive effects for the elderly and non-elderly population 41

7. Top- and bottom- sensitive redistributive effects 45

8. Conclusion 48

References 51

Annex A: Details on the HFCS-EUROMOD implementation 54

Annex B: The redistributive effects relative to market income $\quad 59$

\section{FIGURES}

Figure 1. Rank correlation between the distribution of equivalised disposable income and equivalised net wealth - 2017

Figure 2. Distribution of individuals across quartiles of equivalised disposable income and equivalised net wealth - OECD16 average - 2017

Figure 3. Tax revenues and social benefit expenditure as percentage of GDP

Figure 4. The redistributive process in the two frameworks 28

Figure 5. Rank correlation between equivalised disposable income and equivalised disposable income plus net annuitised net wealth - 2017

Figure 6. The distribution of individuals across quartiles of equivalised disposable income and equivalised disposable income plus net annuitised net wealth - OECD average - 2017

Figure 7. The redistributive effects of tax-benefit systems relative to market plus pension income, overall population - 2017

Figure 8. Relative redistributive effects in two frameworks

Figure 10. The size of the tax-benefit instruments, overall population - $2017 \quad 36$

Figure 11. Progressivity of personal income and wealth-related taxes in the joint income-wealth framework 40

Figure 12. The redistributive effects for non-elderly, relative to market plus pension income - $2017 \quad 43$

Figure 13. The redistributive effects for elderly, relative to market plus pension income - 2017

\section{TABLES}

Table 1. Taxation of capital, rental and private pension income (levied at personal level) - 2017 15

Table 2. Wealth-related taxation (levied at personal level) 16

Table 3. Housing and savings related tax expenditures - $2017 \quad 20$

Table 4. Asset tests in minimum income schemes - $2017 \quad 22$

Table 5. Asset tests in other benefit schemes (only ones which are included in simulations) - 2017 23

Table 6. Kakwani indices, overall population - $2017 \quad 38$

Table 7. Redistributive effects including vs. excluding non-liquid assets, overall population - $2017 \quad 41$

Table 8. Redistributive effects including vs. excluding non-liquid assets, elderly population - $2017 \quad 45$

Table 9. Top and bottom sensitive redistributive effects, overall population $-2017 \quad 47$ 


\section{Introduction}

1. Over the last decades there has been an increasing interest in the level and evolution of inequality, and in the effect that government interventions can have. A major reason is that rising inequality in incomes before taxes and benefits in many OECD countries has only partly been offset by public redistribution and redistribution has weakened over the 1990s and early 2000s, even when market inequality did not increase further (Causa \& Hermansen, 2019). The main focus of academic and policy debates has indeed been on household incomes, even though the most striking distributional trends relate to wealth rather than income. After the Second World War private wealth accumulation has continuously increased such that aggregate private-wealth to national-income ratios have nowadays returned to early 20th century levels, ranging from $300 \%$ to $600 \%$ (Piketty, 2014). Moreover, household wealth is distributed much more unequally than household incomes, with top-10\% wealth shares being about twice as high as top-10\% income shares across the OECD on average (Balestra \& Tonkin, 2018). Therefore, it is increasingly argued that more prominence should be given to the joint distribution of income and wealth (Jäntti, Sierminska, \& Smeeding, 2008; OECD, 2013; Stiglitz, Sen, \& Fitoussi, 2009).

2. Most redistributive studies focus on the effect of income taxes and social benefits. However, over the last years strong arguments have been made for broadening the scope of wealth-related taxes ${ }^{1}$ as a way to raise government revenues. This is not only because this form of taxation (and then especially recurrent taxes on immovable property) may be less detrimental to growth (Arnold, et al., 2011; Bach, Beznoska, \& Steiner, A wealth tax on the rich to bring down public debt? Revenue and distribution effects of a capital levy in Germany, 2014; Piketty, 2014), but also because of its redistributive potential. Yet, empirical evidence on the redistributive effects of both existing and hypothetical wealth-related taxes is largely missing. This negligence is partly due to the lack of high-quality micro-level information: data sources, such as the EU-Statistics on Income and Living Conditions (EU-SILC) include only very limited information on household wealth. This has started to change in recent years, including through the introduction of the Eurosystem Household Finance and Consumption Survey (HFCS). The HFCS is by itself, however, not suitable for redistributive analysis, because for most countries it only contains information on gross incomes.

3. In this paper, we study redistribution through taxes and benefits within a joint income-wealth framework, by using data from the second wave of the HFCS as input for the EU-wide tax-benefit microsimulation model EUROMOD. In this way EUROMOD provides an estimation of disposable incomes and the different parts of the tax-benefit system for the observations included in the HFCS. Based on this information we evaluate the redistributive effects of tax-benefit systems against the joint income-wealth distribution instead of the income distribution alone. Wealth refers here to net worth, which is defined as the sum of real and financial assets less liabilities. Real assets mainly include real estate, self-employment business wealth, vehicles and valuables, while financial assets are for instance deposits, shares, bonds, etc.. Both mortgage and non-mortgage debt are taken into account. ${ }^{2}$ We show the redistributive effects of

\footnotetext{
${ }^{1}$ With the term 'wealth-related' taxes we refer to all types of taxes levied on (parts of) wealth, their transfer and/or their yields. 'Net wealth tax' is used to denote the annual tax on the stock of net wealth.

2 The wealth concept does not cover public wealth such as entitlements to public and occupational pension plans. Inherited wealth is included as long as it is not consumed. See Section 4 for more information.
} 
taxes on wealth and wealth transfers (recurrent taxes on real estate, transfer taxes on real estate, recurrent net wealth taxes, inheritance and gift taxes) alongside those of the more often studied redistributive instruments: personal income taxes (PIT), capital income taxes (KIT), social insurance contributions (SIC), public social benefits. The redistributive effect of each tax-benefit instrument is decomposed into its size and progressivity. To set up the joint income-wealth assessment framework we extend indicators developed in the asset-based poverty literature (Balestra \& Tonkin, 2018; Brandolini, Magri, \& Smeeding, 2010; Kuypers \& Marx, 2018). In particular, we transform the stock of wealth into yearly annuities taking into account the expected remaining life time and add this yearly amount to income. The distribution of this sum is then considered as the joint distribution of income and wealth. ${ }^{3}$

4. The paper builds on and extends an earlier pilot study (Kuypers, Figari, \& Verbist, 2019), which evaluated redistributive effects in a joint income-wealth framework for tax-benefit policies of around 2009 in six EU countries included in the first wave of the HFCS (Belgium, Finland, France, Germany, Italy and Spain). It updates the analysis to the second wave of the HFCS, applying tax-benefit policies as they were in place in 2017, and extends it to ten additional European OECD countries (Austria, Estonia, Greece, Hungary, Ireland, Luxembourg, Poland, Portugal, the Slovak Republic, Slovenia). ${ }^{4}$

5. Our results show that expressing living standards in terms of both income and wealth leads to a considerable re-ranking of individuals ${ }^{5}$ : those with the lowest (highest) income are not necessarily those with the lowest (highest) net wealth. This, in turn, implies a lower redistributive impact of tax-benefit systems than when considering income alone. This is the case for all tax-transfer instruments we consider (personal income taxes, capital income taxes, social insurance contributions, wealth-related taxes and public social benefits). It reflects, on the one hand, that the size of the redistributive instruments is smaller when using the joint income-wealth framework, and on the other hand their lower degree of progressivity, except for social benefits.

6. The analysis is novel on several levels. First, we provide a more recent estimation of redistributive effects from a joint income-wealth perspective, which allows to draw clear policy conclusions and suggest potential reforms to policy makers. Second, by including more countries, we are able to study the effect of including wealth in the assessment framework among a larger variety of tax-benefit systems including for instance countries with a flat personal income tax (e.g. Hungary, Estonia) and countries that do not tax intergenerational wealth transfers (e.g. Austria, Estonia, the Slovak Republic). This larger panel of countries also shows a wider range of rank correlations between income and wealth (i.e. the extent to which low or high income and wealth are concentrated among the same individuals). It is for instance very low in Poland and relatively high in France and Spain. In other words, the updated and extended analysis will give us a better insight into which types of policies are redistributive in which institutional settings taking into account the distribution of both income and wealth. Third, we do not only perform our analysis for overall household wealth holdings, but also distinguish between liquid and non-liquid assets. Finally, we also particularly focus on the position of the elderly as they are known to often combine low income with median to high wealth (Kuypers \& Marx, 2019).

\footnotetext{
${ }^{3}$ When the income and wealth distributions are considered separately capital income is included in total income. However, when the wealth annuity is added to income, capital income is not included as it would no longer exist when wealth is annuitised (see Section 4).

${ }^{4}$ Latvia and the Netherlands are the only two OECD countries included in the second wave of the HFCS that are not included in the present analysis mainly due to their small sample sizes. In addition, Salverda (2015) shows for the Netherlands a large discrepancy in the share of the top $1 \%$ wealthiest estimated on the HFCS compared to administrative statistics.

${ }^{5}$ In studies of the distribution of income it is conventional to use individuals as the main unit of analysis, while in the wealth literature households are more often used as unit of analysis. Since we combine both and want to keep the comparison to the existing literature on redistribution as close as possible we take here the perspective of individuals.
} 


\section{8 | DELSA/ELSA/WD/SEM(2021)4}

7. This paper focuses on the difference in joint income-wealth inequality before and after redistribution through taxes and benefits, rather than providing an estimation of the actual level of wealth and income inequality or the mechanisms explaining long-run evolutions of inequality. While the latter two have been the topic of many recent studies, the effect of the tax and transfer system has so far only been studied from the perspective of the income distribution. Our analysis is limited in that capital gains taxes and taxes levied at the corporate level are not included. Nevertheless, it is reasonable to assume that the main conclusion that redistribution is lower when the distribution of wealth is accounted for would remain valid.

8. The paper is organised as follows. In Section 1. we explain why it is interesting to study redistributive effects against both income and wealth and how these two distributions are correlated with each other. In Section 2. we describe the role of wealth in tax and social policies. In particular, we list the policies in the 16 European OECD countries that rely in one way or another on information on (income from) wealth. The data and methods are described in Section 3. In Section 4. we then assess the redistributive effects against the joint income-wealth framework, comparing it to results obtained using the "traditional" approach, i.e. against the distribution of income alone. While all wealth is taken into account to construct the joint distribution in Section 5, we distinguish between liquid and non-liquid assets in Section 6. In Section 7 we zoom in on the particular situation of the elderly. Section 8 presents a sensitivity analysis and the last section concludes and puts forward some policy recommendations.

\section{The joint distribution of income and wealth}

9. Countries with low income inequality sometimes have high wealth inequality and vice versa (OECD, 2020; Balestra \& Tonkin, 2018; Skopek, Buchholz, \& Blossfeld, 2014). Therefore, it is increasingly argued that more prominence should be given to the joint distribution of income and wealth (Jäntti, Sierminska, \& Smeeding, 2008; OECD, 2013; Stiglitz, Sen, \& Fitoussi, 2009). Although there exist clear links between income and wealth through savings and borrowing constraints, their correlation is far from perfect. Possible factors mitigating the income-wealth relationship include asset portfolio choices, life cycle effects, life cycle choices such as marriage or having children and intergenerational transfers (Jäntti, Sierminska, \& Smeeding, 2008).

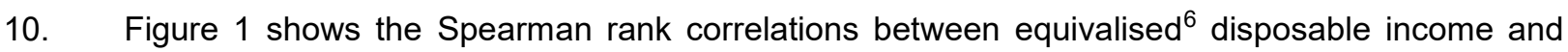
equivalised net wealth for the 16 European OECD countries reviewed in this study. Figure 2 then illustrates what these rank correlations entail for the distribution of individuals across quartiles of disposable income and net wealth. In case of a perfect correlation the options ' 11 ' (i.e. individuals belonging to the first quartile of both the income and the wealth distribution), '22', '33' and ' 44 ' would correspond to $25 \%$ each, i.e. summing up to $100 \%{ }^{7}$

11. Both figures clearly illustrate that rank correlation between income and wealth is far from perfect in all countries. Across the 16 countries the rank correlation coefficient is on average equal to 0.45 . Such an imperfect correlation between income and wealth is also observed in Figure 2. On average, only $38 \%$ of individuals live in a household that is situated in the same quartile in the income and wealth distribution:

\footnotetext{
${ }^{6}$ We use the OECD modified equivalence scale for both income and wealth. There is no consensus in the literature on whether it is appropriate to apply an equivalence scale to wealth and if so which scale is relevant. Yet, when considering wealth as a resource supporting current consumption, as we do in this paper, it is generally considered appropriate to apply the same equivalence scale to income and wealth (OECD, 2013, p. 178).

${ }^{7}$ Note that disposable income and net wealth distributions do not have the same shape and a difference of one quartile in wealth does not have the same 'effect' in people's life than a difference of one quartile in income.
} 
$11 \%$ in the first quartile of both distributions, $7 \%$ in the second, $8 \%$ in the third and $12 \%$ in the highest quartile. Hence, $62 \%$ belong to different income and wealth quartiles.

12. In general, rank correlation is higher at the bottom and the top than in the middle. Yet, even at the extremes there is a non-negligible share of people occupying very different positions in the income and wealth distribution. For example, on average almost $3 \%$ of people live in a household that have an income in the lowest quartile, but belong to the highest wealth quartile, for $2.3 \%$ the opposite is true. This means that an important share of households on low incomes might have the necessary assets to smooth consumption and to face unexpected costs or are able to borrow against their assets. In contrast, some households on median to high incomes are vulnerable if confronted with an income loss as they have hardly any wealth to fall back on (Kuypers \& Marx, 2019).

13. France and Spain show the highest rank correlation. Particularly in France this is mainly due to high rank correlation at the top; $14.6 \%$ belong to the top income quartile as well as to the top wealth quartile, which is the highest share across all countries considered here. ${ }^{8}$ In contrast, rank correlation is very low in Poland due to a weak correlation between income and wealth throughout the distribution. However, in line with the general picture, rank correlation is a little higher at the bottom and the top.

\section{Figure 1. Rank correlation between the distribution of equivalised disposable income and} equivalised net wealth - 2017

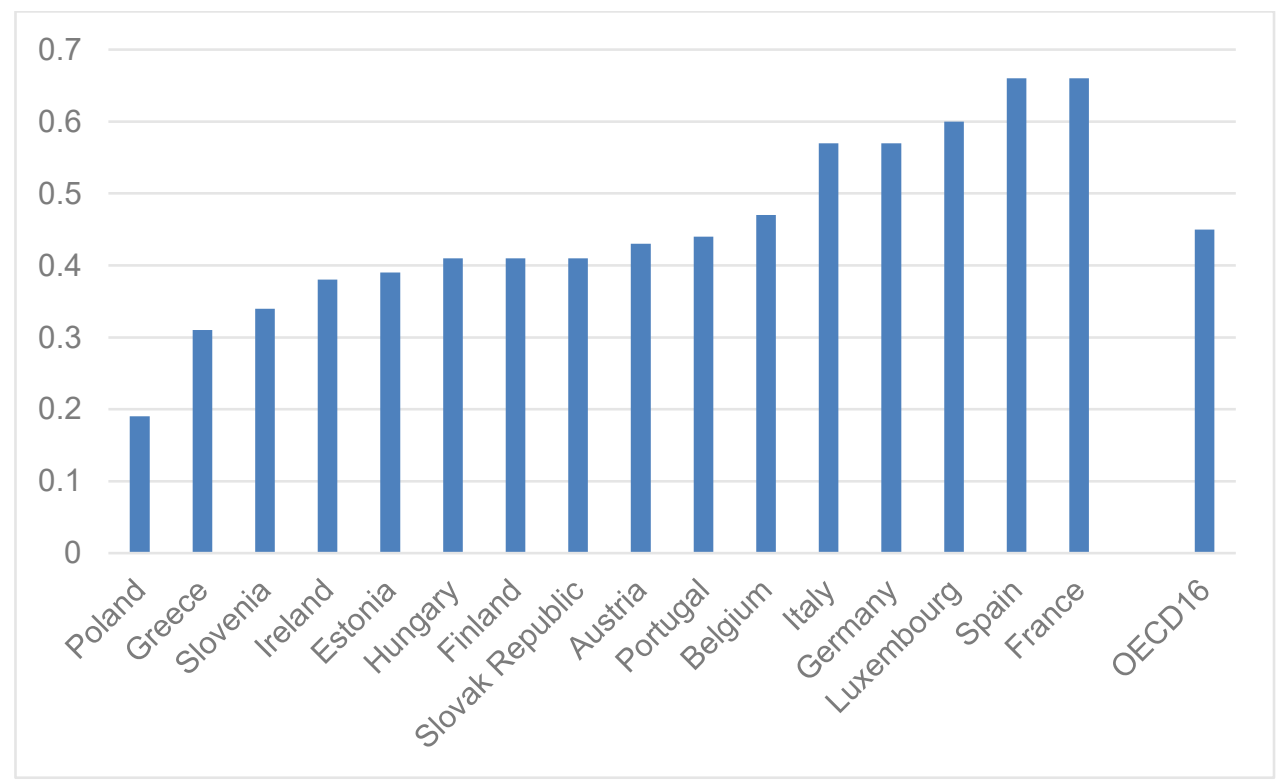

Source: Authors' calculations based on HFCS wave 2 and EUROMOD (for more details see Section 4 on data and methods).

\footnotetext{
8 The distribution of individuals across quantiles is only shown for the OECD16 average, but they are also available upon request for all countries separately. Although the exact shares in each quartile slightly differ, the overall picture is the same in all countries.
} 
Figure 2. Distribution of individuals across quartiles of equivalised disposable income and equivalised net wealth - OECD16 average - 2017

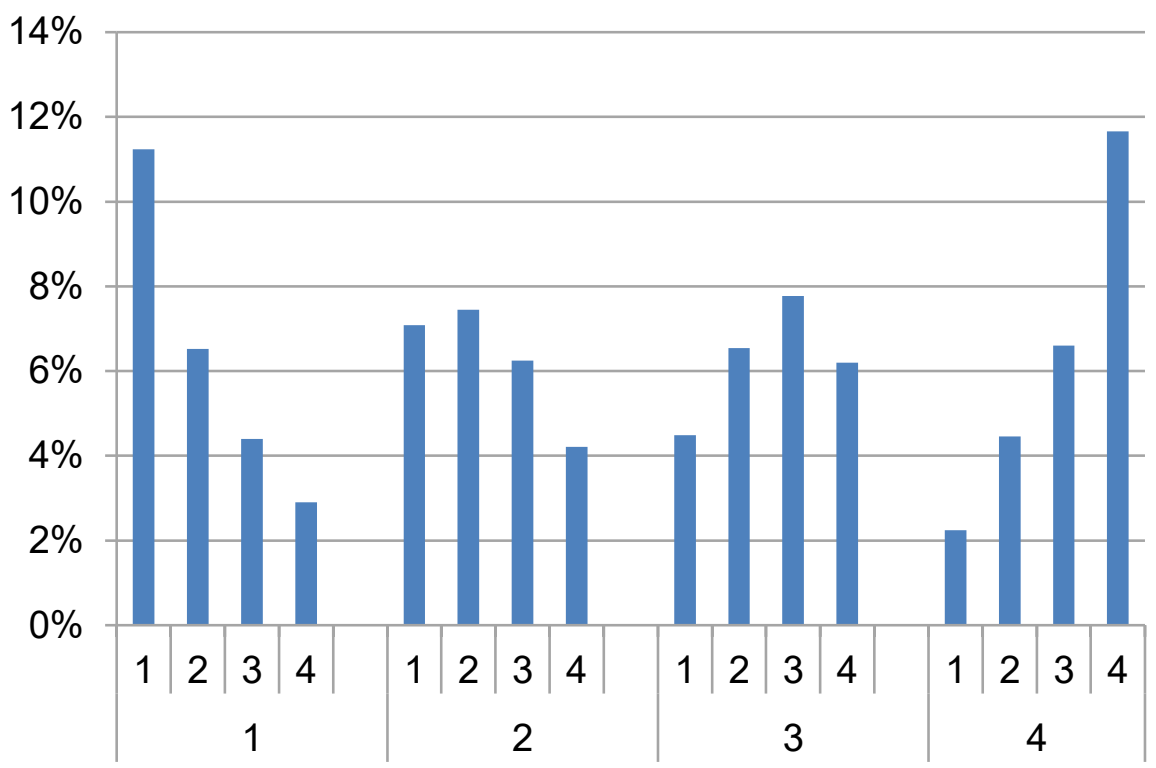

Note: Bottom number refers to income quartile, top number to net wealth quartile.

Source: Authors' calculations based on HFCS wave 2 and EUROMOD (for more details see Section 4 on data and methods).

14. A non-negligible share of individuals live in so-called income-poor wealth-rich households or income-rich wealth-poor households, confirming earlier analysis (Kuypers \& Marx, 2019; Kuypers \& Marx, 2018). As mentioned above, one of the main factors attenuating the income-wealth relationship is the lifecycle effect: young people may earn high incomes but have not yet had the time to accumulate wealth, while pensioners generally earn a low income relative to the working-age population but often hold medium to high wealth, as usually they have already paid off their mortgage or may have received an inheritance (OECD, 2020; Balestra \& Tonkin, 2018). Therefore, re-ranking between the income and wealth distribution is more common among the elderly than among the working-age population. Redistributive effects among the elderly are more strongly affected by taking into account wealth (see Section 7). Yet, we show below that our results also hold when only looking at the working-age population. In other words, even if the lifecycle effect were filtered out, rank correlation between income and wealth would still be imperfect. Since these households may face specific problems different from households with similar levels of income and wealth it is important to analyse whether these are addressed by taxes and social policies.

\section{Tax-benefit systems and the role of wealth}

15. The observed distributions of disposable income and net wealth reflect the distribution of market incomes and the relative size and design of taxes and benefits with respect to the overall resources of a given economy. Figure 3 depicts the revenues for different types of taxes and contributions and the public expenditures on social benefits as a percentage of Gross Domestic Product (GDP).

16. The countries covered in the analysis present a wide range of the size of government intervention in terms of cash benefits and direct taxes as a percentage of GDP, which is smallest in Estonia, Ireland and Slovak Republic and highest in Finland, Belgium and France. On the revenue side, personal income taxes generally generate the most revenues followed by social-insurance contributions. The exceptions are Slovak Republic, Hungary, Poland and Slovenia where the revenues from social-insurance 
contributions are most important. Capital gains and wealth-related taxes typically contribute much less to the budget representing, on average across the 16 OECD countries, only $0.34 \%$ and $1.18 \%$ of GDP respectively. Wealth-related taxes generate the highest revenues in France, Belgium and Spain, with 3.5\%, $2.7 \%$ and $2.3 \%$ of GDP, respectively. On the spending side, the allocation of government resources to social benefits (except public pensions) ranges between 10\% of GDP in Estonia and Poland and $20 \%$ of GDP in Belgium and France. Public pensions represent a high share of public resources (over $10 \%$ of GDP) in Portugal, Greece, Italy, Austria, Finland and France. In Greece this share is higher than the resources going to all other social benefits.

\section{Figure 3. Tax revenues and social benefit expenditure as percentage of GDP}

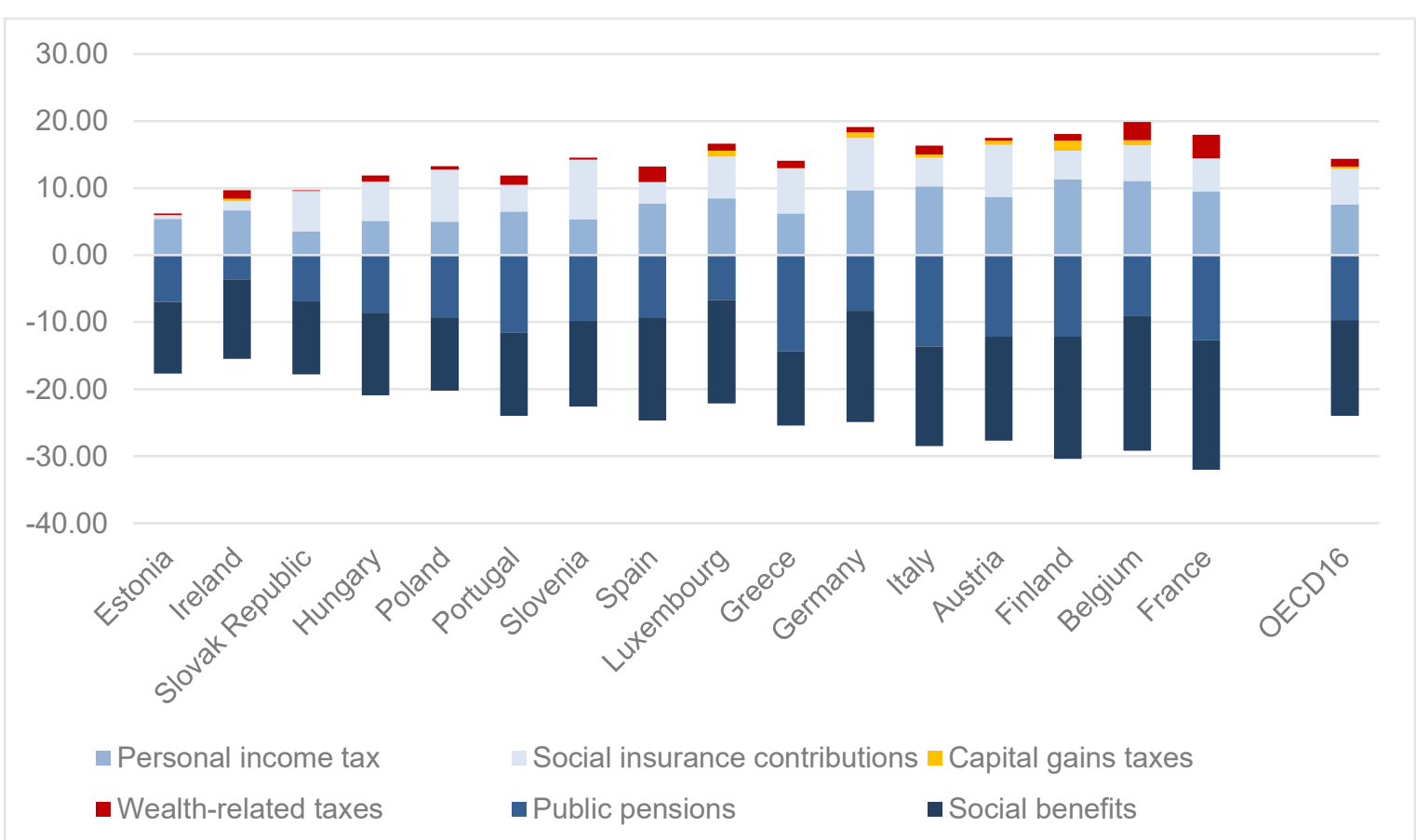

Notes: Figures for last available year, in general 2018 for tax revenues (2017 for Greece and Poland) and 2015 for benefit expenditures (2014 for Poland). Wealth-related taxes refer to all types of taxes levied on (parts of) wealth, their transfer and/or their yields (category '4000' in the OECD tax categorisation). Where possible tax revenues only refer to taxes paid by individuals and households (not possible for taxes on financial and capital transactions and non-recurrent taxes on property). Countries are ranked in ascending order of total budget (taxes plus benefits). Source: OECD Revenue Statistics Database and OECD Social Expenditure Database.

17. Beyond their size, the design of tax-benefit instruments is crucial for the redistributive effect and hence the observed distributions of disposable income and net wealth. In the framework of this paper it is particularly relevant how and in which instruments wealth and income from wealth is taken into account. Table 1 to Table 5 provide an overview of policies in which wealth is taken into account and a brief summary of how this is done in practice. The tables describe the policies as they existed in 2017, the year for which the analyses of this paper are carried out. Capital gains taxes are not discussed as these are not taken into account in our simulations (see OECD (2018) for an overview).Furthermore, as the focus is on taxes levied on individuals, corporate income and wealth taxes are also not discussed (see Harding \& Marten (2018) for more information on these taxes and the interplay with individual taxes).

18. The most obvious aspects of the tax-benefit system in this respect are the taxes levied on (components of) wealth, wealth transfers and income generated from wealth. These are listed in Table 1 and Table 2. First, 12 of the 16 countries tax capital income separately from all other types of income taxed in a progressive personal income tax (except Hungary and Estonia which have flat rate personal income 
taxes). These separate capital income taxes are generally levied at a low flat rate. Finland is a special case as it has a progressive tax with two rates on capital income since 2012 (where part of self-employment income is also considered as capital income). Some countries vary rates depending on the type of capital income (interest, dividend, rent, etc.). Only France taxes all types of capital income progressively in the personal income tax, while Ireland, Estonia and the Slovak Republic tax some types of capital income in the personal income tax (but in the case of Estonia the PIT is a flat tax). Table 1 also describes separately the tax treatment of rental income, which is taxed in the personal income tax more often than capital income, although typically important deductions apply (see also Table 3). Private pensions are in the majority of countries also taxed progressively in the PIT. In Hungary and Poland they are not taxed.

19. Most countries also levy recurrent taxes on real estate, transfer taxes on real estate ${ }^{9}$ and inheritance and gift taxes. In terms of the recurrent real estate tax most countries use a notion of taxable or cadastral value as tax base, while there are some countries who use market value (Hungary, Ireland, Slovenia) or property size in $\mathrm{m}^{2}$ (Hungary ${ }^{10}$, Poland, the Slovak Republic). Tax rates are often set at the municipal level, although generally within statutory limits defined at the central level. The real property transfer tax is typically levied on the market value of the property (i.e. usually the sale value), except in Italy where revalued cadastral values are used as tax base. Some countries also levy a (small) tax on the registration of a mortgage (Belgium, Italy, Portugal, Spain).

20. Inheritances and gifts are subject to taxation in all countries considered here with the exception of Austria, Estonia and the Slovak Republic. ${ }^{11}$ The tax is always levied on the recipient of the inheritance or gift, which is different from so-called estate taxes where the whole inheritance left by the deceased is taxed. Inheritances and gifts are generally taxed in a progressive way, either through a progressive tax schedule (all countries except Hungary, Ireland, Italy, Luxembourg and Portugal) and/or by granting large allowances of several thousands of euros (Germany, Greece, Ireland, Italy). Tax rates usually depend on the relationship between the donor and recipient with more favourable tax rates (or exemptions) for partners and lineal heirs (i.e. descendants and ascendants) than other relatives or non-related beneficiaries. The receipt of the family home and business assets is often exempt from taxation.

21. Among the countries studied in this paper only France and Spain had a recurrent net wealth tax in place in $2017 .{ }^{12}$ Due to the increased mobility of wealth and increased international tax competition many countries have abolished their net wealth taxes over the last decades: Sweden (2007), Luxembourg (2006), Finland (2006), Iceland (2006), Germany (1997), Austria (1995), Denmark (1995). ${ }^{13}$ In both France and Spain the net wealth tax is progressive and is levied only on wealthy individuals. Only those who own at least EUR 1300000 in France or EUR 700000 in Spain in net wealth (i.e. assets minus liabilities) are subject to the tax. Italy and Belgium levy a specific wealth tax: Italy taxes bank accounts and financial assets yearly, while Belgium taxes private pension savings once people turn 60 years old or when their

\footnotetext{
${ }^{9}$ In some countries also transfers of (some) financial assets are taxed. These are not part of our simulations and are hence not discussed in this paper. An overview can be found in OECD (2018).

10 In Hungary municipalities can decide on whether to tax the market value of a property or its size in $\mathrm{m}^{2}$.

11 In Portugal there is no actual inheritance and gift tax, but a stamp duty applies to inheritances and gifts.

12 Since 1 January 2018 France replaced its general net wealth tax (Impôt de solidarité sur la fortune) with a real estate wealth tax (Impôt sur la fortune immobilière). Spain abolished its net wealth tax in 2008, but reintroduced it in 2011.

${ }^{13}$ Luxembourg still has a net wealth tax on corporations. The Netherlands had an actual net wealth tax in place since 1965, replaced in 2001 by a presumptive capital income tax (Vermogensrendementheffing) which implicitly still functioned as a net wealth tax. Since 2017 the presumptive rate of return follows actual rates of return, differs among asset types and increases with net wealth. Iceland reintroduced its wealth tax as a temporary emergency measure between 2010 and 2014.
} 
pension saving contract reaches its $10^{\text {th }}$ anniversary. These countries with general or specific net wealth taxes in place are also the countries with the highest wealth tax revenues (Figure 3).

22. Wealth tax systems currently largely focus on the taxation of real estate, which relates to several reasons. First, real estate often takes up the largest share of households' asset portfolios such that the revenue potential is higher for taxes on real wealth than for financial assets. Second, real estate is visible and immobile limiting possibilities for behavioural responses and tax evasion. Finally, most countries do not have a general net wealth register, but they do keep records of real estate ownership and transfer.

23. Wealth is not only taxed, there are also programmes in place to encourage asset accumulation. Part of these programmes are tax reliefs ${ }^{14}$, typically granted for three types of assets: real estate, private pension savings and capital income (Table 3). First, the ownership of the own private residence is often encouraged through mortgage tax reliefs, mostly for interest payments but sometimes also for capital repayments. Mortgage reliefs are mainly granted in the form of a deduction (Austria, Belgium, Estonia, Finland and Luxembourg); as a tax credit (Italy, Portugal and Spain); or as a tax relief at source (Ireland). Several countries have decided to abolish these tax reliefs over the years, with existing mortgages still remaining eligible: France (2011), Portugal (2012), Ireland (2013), Spain (2013), Austria (2016), Belgium (2017 in the Brussels Capital Region, 2020 in the Flemish Region). Some countries also grant tax reliefs for other real estate, usually only when it is rented out (for Belgium the restriction to rented out real estate does not apply, all real estate is in principle eligible). The tax relief either applies as a deduction of mortgage interests (Austria, Germany, Ireland, Belgium) or as a deduction of an arbitrary percentage of rental income representing the costs incurred by the owner (Italy (5\%), Slovenia (10\%), Estonia (20\%), Luxembourg $(35 \%)$, Belgium (40\%), Spain $(60 \%))$.

24. All countries except Greece also have a tax relief in place for private pension savings. It is mostly granted in the form of a deduction of actual contributions made, with the exception of France where the deduction takes the form of $10 \%$ of earnings. In Belgium, Hungary, Poland and Portugal a tax relief for contributions to private pension savings is granted as a tax credit.

25. Capital income often already receives favourable tax treatment by taxing it separately from other income at lower flat rates, but in several countries there are also tax reliefs in place. While Germany has a tax relief for all types of capital income jointly, Slovenia provides relief for interests on deposits and Belgium and Luxembourg only for interests on savings accounts. Estonia, Finland and France fiscally encourage stock ownership by granting tax relief for dividends.

26. Wealth is also taken into account in the benefit side of the redistributive process. In particular, in determining the eligibility conditions for means-tested benefits many countries include asset or wealth conditions that need to be met. Analysing the asset test in minimum-income protection schemes in EU member states, Marchal et al. (2020 forthcoming) distinguish between two main types of asset tests. The first and most prevalent type applies a disqualification threshold, i.e. when assets are above a certain threshold applicants become immediately ineligible. In other words, assets need to be realised first and only after they drop below the threshold minimum-income benefits will be awarded. The second type takes assets into account in a given percentage or at a fictional rate of return which is added to the income in the means-test, such that applicants are eligible to lower minimum income benefits as more assets are available (and eventually at high asset levels also become fully ineligible). Yet, this rate of return is usually higher than actual returns received so in practice assets often also need to be realised.

14 In line with OECD (2010) the different types of tax reliefs are defined as follows:

- Exemption: income components which are part of pre-tax income but do not need to be declared to the tax authority and hence are not part of the concept of taxable income

- Deduction: amount that is subtracted from pre-tax income

- Credit: amount subtracted from the tax liability 
27. Table 4 describes the asset tests in minimum-income protection schemes as they existed in 2017 in the 16 countries included in this paper. The disqualification type of asset test is applied in Austria, Germany, Greece, Finland, Hungary, Slovenia and the Slovak Republic, while Belgium, Ireland and Luxembourg take into account a rate of return and Portugal adopts a mixed approach with a relatively high disqualification threshold and below assets are taken into account at a fictional rate of return. Estonia relies on a discretionary assessment of the assets owned by applicants. France and Poland do not have a statutory asset test in place, but if minimum-income beneficiaries' life style and means declared do not match there will be an inquiry. Italy and Spain did not have a national minimum income scheme in place in $2017 .{ }^{15}$

28. Actual thresholds and rates of return applied vary considerably across the countries. Also the types of assets that are considered in the asset test differ. In most countries the family home is not taken into account, although some countries list requirements for instance in relation to its size (e.g. Germany). In Austria the family home is in principle not exempt, but minimum-income benefits can be provided as a loan against the homes' value. The value of other real estate property is almost always taken into account and in "disqualifying countries" the ownership of other real estate is often already a disqualifying condition on its own. Movable property is considered in the asset test in all countries, although often a limited amount of cash and private pension savings are allowed. A number of countries explicitly mention the inclusion of the value of vehicles in the asset test, with certain exemptions such as when vehicles are used for work or to transport disabled, elderly or children. Greece explicitly states that the ownership of certain (luxury) goods (such as boats) immediately lead to disqualification, while other countries list goods that should not be taken into account (e.g. household goods, goods of children, ...).

29. There are many other means tested (cash or in-kind) benefits where assets or wealth are taken into account. For instance, rent allowances and eligibility to live in social housing are obviously only granted when applicants do not own any real estate. As population ageing continues asset testing is also widely debated in the frame of long-term care policies (OECD, 2020). While an extensive description of all benefits in which asset-testing is adopted falls beyond the scope of this paper, Table 5 provides selected examples from Boone et al. (2019) for which we have specifically adapted EUROMOD so that the asset-test is taken into account in the simulations.

\footnotetext{
15 In Italy a national minimum income scheme has been introduced in 2018 (Reddito di Inserimento Rel) and reformed since 2019 (Reddito di Cittadinanza RdC). The scheme includes an asset-test based on the Indicator of Economic Equivalent Situation (ISEE), which takes into account, in addition to most income sources, the revaluated cadastral value of immovable properties and $20 \%$ of financial assets.
} 
Table 1. Taxation of capital, rental and private pension income (levied at personal level) - 2017

\begin{tabular}{|c|c|c|c|}
\hline & Capital income & Rental income & Private pensions \\
\hline Austria & $\begin{array}{l}\text { Income from deposits taxed separately at } \\
25 \% \text {, all other capital income at } 27.5 \%\end{array}$ & Taxed progressively in PIT & Taxed progressively in PIT \\
\hline Belgium & Taxed separately at flat rate of $30 \%$ & $\begin{array}{l}60 \% \text { of rental income taxed progressively } \\
\text { in PIT if real estate rented for professional } \\
\text { purposes, } 140 \% \text { of cadastral income } \\
\text { taxed progressively in PIT if real estate } \\
\text { rented for private purposes or not rented }\end{array}$ & $\begin{array}{l}\text { No taxation when received, but } \\
\text { accumulated capital taxed (see } \\
\text { Table 2) }\end{array}$ \\
\hline Estonia & $\begin{array}{l}\text { All capital income except dividend income } \\
\text { taxed in PIT (flat tax PIT) }\end{array}$ & Taxed separately at flat rate of $20 \%$ & $\begin{array}{l}\text { Taxed separately at flat rate of } \\
10 \%\end{array}$ \\
\hline Finland & $\begin{array}{l}\text { Dual income tax with capital income } \\
\text { (including capital part of self-employment } \\
\text { income) taxed at } 30 \% \text { up to EUR30,000 } \\
\text { and } 34 \% \text { above }\end{array}$ & $\begin{array}{l}\text { Dual income tax with rental income taxed } \\
\text { at } 30 \% \text { up to EUR30,000 and } 34 \% \text { above }\end{array}$ & $\begin{array}{l}\text { Dual income tax with private } \\
\text { pensions taxed at } 30 \% \text { up to } \\
\text { EUR30,000 and } 34 \% \text { above }\end{array}$ \\
\hline France & Taxed progressively in PIT & Taxed progressively in PIT & Taxed progressively in PIT \\
\hline Germany & $\begin{array}{l}\text { Taxed separately at flat rate of } 25 \% \text { and } \\
\text { solidarity surcharge of } 5.5 \%\end{array}$ & Taxed progressively in PIT & Taxed progressively in PIT \\
\hline Greece & Taxed separately at flat rate of $15 \%$ & $\begin{array}{l}\text { Taxed separately at } 15 \% \text { up to } \\
\text { EUR } 12,000 \text {, at } 35 \% \text { between EUR } 12,000 \\
\text { and EUR35,000 and at } 45 \% \text { above } \\
\text { EUR35,000 }\end{array}$ & Taxed progressively in PIT \\
\hline Hungary & Taxed separately at flat rate of $15 \%$ & Taxed in (flat tax) PIT & Not taxed \\
\hline Ireland & $\begin{array}{l}\text { Interest from deposits taxed separately at } \\
39 \% \text {, all other capital income taxed } \\
\text { progressively in PIT }\end{array}$ & Taxed progressively in PIT & Taxed progressively in PIT \\
\hline Italy & $\begin{array}{l}\text { Taxed separately at flat rate of } 26 \% \text {, } \\
\text { exceptional } 12.5 \% \text { on interests from } \\
\text { government bonds and } 20 \% \text { on annuities } \\
\text { of (some) private pension funds }\end{array}$ & $\begin{array}{l}\text { Either taxed separately at } 21 \% \text { or } \\
\text { progressively in PIT }\end{array}$ & $\begin{array}{l}\text { Taxed separately at flat rate of } \\
15 \% \text { or } 26 \% \text { if paid out as capital }\end{array}$ \\
\hline Luxembourg & $\begin{array}{l}\text { Interest income taxed separately at } 20 \% \\
\text { Withholding tax on dividend income at } \\
15 \% \text { ( } 50 \% \text { of dividend income taxed in PIT } \\
\text { from which already paid withholding tax is } \\
\text { subtracted) }\end{array}$ & Taxed progressively in PIT & $\begin{array}{l}\text { Taxed progressively in PIT, yet } \\
50 \% \text { exemption }\end{array}$ \\
\hline Poland & Taxed separately at flat rate of $19 \%$ & $\begin{array}{l}\text { Either taxed progressively in PIT or } \\
\text { according to separate rules }\end{array}$ & Not taxed \\
\hline Portugal & Taxed separately at flat rate of $28 \%$ & $\begin{array}{l}\text { Either taxed progressively in PIT or at flat } \\
\text { rate of } 28 \%\end{array}$ & Taxed progressively in PIT \\
\hline $\begin{array}{l}\text { Slovak } \\
\text { Republic }\end{array}$ & $\begin{array}{l}\text { Dividend income taxed separately at flat } \\
\text { rate of } 7 \% \text {, other capital income taxed } \\
\text { progressively in PIT }\end{array}$ & Taxed progressively in PIT & $\begin{array}{l}\text { Taxed separately at flat rate of } \\
19 \%\end{array}$ \\
\hline Slovenia & $\begin{array}{l}\text { Capital income taxed separately at flat rate } \\
\text { of } 25 \% \text { ( } 15 \% \text { after } 5 \text { years of asset } \\
\text { ownership, } 10 \% \text { after } 10 \text { years and } 5 \% \\
\text { after } 15 \text { years) }\end{array}$ & Taxed progressively in PIT & Taxed progressively in PIT \\
\hline Spain & $\begin{array}{l}\text { Taxed separately at } 19 \% \text { up to EUR6,000, } \\
\text { at } 21 \% \text { between EUR6,000 and } \\
\text { EUR50,000 and at } 23 \% \text { above }\end{array}$ & $\begin{array}{l}40 \% \text { of rental income taxed progressively } \\
\text { in PIT if property rented out or } 2 \% \text { of } \\
\text { cadastral value taxed if property if not } \\
\text { rented ( } 1.1 \% \text { if cadastral value has been } \\
\text { adjusted after } 1 / 1 / 1994)\end{array}$ & Taxed progressively in PIT \\
\hline
\end{tabular}


Table 2. Wealth-related taxation (levied at personal level)

\begin{tabular}{|c|c|c|c|c|}
\hline Country & Recurrent real estate tax & Real estate transfer tax & Inheritance \& gift tax & $\begin{array}{l}\text { General/specific } \\
\text { net wealth tax }\end{array}$ \\
\hline Austria & $\begin{array}{l}\text { Progressive tax levied on cadastral value with rates } \\
\text { between } 0.05 \% \text { and } 0.2 \% \text { and municipal coefficients of up } \\
\text { to } 500 \% \text {. An additional tax applies to vacant land not used } \\
\text { for agricultural purposes of } 1 \% \text { above an exempted } \\
\text { amount of EUR } 14600\end{array}$ & $\begin{array}{l}\text { Flat tax of } 3.5 \% \text { with exemption of } \\
\text { EUR } 1100 \text { (EUR } 365000 \text { for agricultural } \\
\text { property and EUR } 900000 \text { for business } \\
\text { property). In case of transfer without } \\
\text { payment (i.e. inheritance or gift) the tax } \\
\text { rate is } 0.5 \% \text { for the first EUR } 250000 \text {, } \\
2 \% \text { up to EUR } 400000 \text { and } 3.5 \% \text { above } \\
\text { EUR } 400000\end{array}$ & & \\
\hline Estonia & $\begin{array}{l}\text { Tax on value of land with rates set by local authorities } \\
\text { between statutory limits of } 0.1 \% \text { and } 2.5 \% \text {, residential land } \\
\text { is largely exempted }\end{array}$ & $\begin{array}{l}\text { Stamp duty applies to registration of a } \\
\text { real estate transfer, but amount is } \\
\text { insignificant relative to value }\end{array}$ & & \\
\hline Finland & $\begin{array}{l}\text { Flat tax levied on taxable value, rates set by municipalities } \\
\text { within statutory limits: between } 0.41 \% \text { and } 0.9 \% \text { for } \\
\text { permanent residences, between } 0.93 \% \text { and } 1.8 \% \text { for other } \\
\text { real estate }\end{array}$ & $\begin{array}{l}\text { Flat tax of } 4 \% \text {, individuals aged between } \\
18 \text { and } 39 \text { purchasing their first owner- } \\
\text { occupied dwelling are exempted }\end{array}$ & $\begin{array}{l}\text { Progressive tax with rates between } 7 \% \text { and } 19 \% \text { for } \\
\text { partners, (grand)children and (grand)parents in the } \\
\text { case of inheritance and between } 8 \% \text { and } 17 \% \text { in the } \\
\text { case of gifts and between } 19 \% \text { and } 33 \% \text { for all other } \\
\text { heirs or beneficiaries, a tax-free allowance of } \\
\text { EUR20,000 for inheritances and EUR5,000 for gifts }\end{array}$ & \\
\hline France & $\begin{array}{l}\text { Flat tax levied on } 50 \% \text { of valeur locative cadastrale for } \\
\text { build property and on } 80 \% \text { for unbuild land, tax rates } \\
\text { determined at different regional levels }\end{array}$ & $\begin{array}{l}\text { Flat tax of } 5.8 \% \text { (reflects sum of several } \\
\text { tax rates: } 4.5 \% \text { departmental tax rate, } \\
1.2 \% \text { municipal tax rate and levy for } \\
\text { collection costs of } 2.37 \% \text { of } \\
\text { departmental tax rate) }\end{array}$ & $\begin{array}{l}\text { Progressive tax with rates between } 5 \% \text { and } 45 \% \text { for } \\
\text { lineal heirs and partners, } 35 \% \text { and } 45 \% \text { for siblings, flat } \\
\text { tax of } 55 \% \text { for relatives of the fourth degree or further } \\
\text { and } 60 \% \text { for all other persons, total exemption for } \\
\text { partners and allowances of between EUR } 100,000 \text { for } \\
\text { children and parents and EUR } 1,594 \text { for non-relatives }\end{array}$ & $\begin{array}{l}\text { General net wealth tax: } \\
\text { Progressive tax with rate } \\
\text { between } 0.5 \% \text { and } 1.5 \% \text {, tax } \\
\text { levied on combined net wealth } \\
\text { of fiscal household if above } \\
\text { EUR1,300,000 (certain assets } \\
\text { are exempt) }\end{array}$ \\
\hline Germany & $\begin{array}{l}\text { Flat tax levied on assessed standard value, tax rate is } \\
\text { result of basic tax rate (between } 0.0026 \% \text { and } 0.01 \% \text {, } \\
\text { differing by type of property, between East and West } \\
\text { Germany and by municipality) and a municipal multiplier }\end{array}$ & $\begin{array}{l}\text { Flat tax of between } 3.5 \% \text { and } 6.5 \% \\
\text { differing across Bundesländer }\end{array}$ & $\begin{array}{l}\text { Progressive tax with rates between } 7 \% \text { and } 30 \% \text { for } \\
\text { Class } 1 \text { (partners, (grand)children, parents and } \\
\text { ancestors in case of inheritance), between } 15 \% \text { and } \\
43 \% \text { for Class } 2 \text { (parents and ancestors in case of gift, }\end{array}$ & \\
\hline
\end{tabular}




\begin{tabular}{|c|c|c|c|c|}
\hline & & & $\begin{array}{l}\text { siblings, } 1^{\text {st }} \text { degree descendants of siblings, step- } \\
\text { parents, children-in-law, parents-in-law, divorced } \\
\text { spouses) and } 30 \% \text { and } 50 \% \text { for Class } 3 \text { (all other } \\
\text { individuals), allowances between EUR500,000 for } \\
\text { partners and EUR20,000 for persons in Class } 2 \text { and } 3 \text {, } \\
\text { often exemptions for family home and business assets }\end{array}$ & \\
\hline Greece & $\begin{array}{l}\text { Main tax is calculated based on an elaborate formula } \\
\text { taking into account different parameters such as } \\
\text { geographic location, surface area in } \mathrm{m}^{2} \text {, use and age of the } \\
\text { property, the outcome of the formula is multiplied by a base } \\
\text { tax rate ranging between EUR } 2 / \mathrm{m}^{2} \text { to EUR } 13 / \mathrm{m}^{2} \\
\text { (exemptions exist for low income households) } \\
\text { An additional progressive tax with rates between } 0.2 \% \text { and } \\
1.15 \% \text { applies to properties over EUR } 200,000\end{array}$ & $\begin{array}{l}\text { Flat tax of } 3 \% \text { and a municipal surcharge } \\
\text { of } 3 \% \text { (i.e. total tax rate is 3.09\%) }\end{array}$ & $\begin{array}{l}\text { Progressive tax with rates between } 1 \% \text { and } 10 \% \text { for } \\
\text { close relatives, between } 5 \% \text { and } 20 \% \text { for relatives and } \\
\text { between } 20 \% \text { and } 40 \% \text { for others, main residence } \\
\text { exempted for children, tax allowance of between } \\
\text { EUR400,000 (spouse, non-adult children) and } \\
\text { EUR6,000 (non-relatives) }\end{array}$ & \\
\hline Hungary & $\begin{array}{l}\text { Tax determined by local authorities with maximum tax rate } \\
\text { either HUF } 1,821 \text { per square meter or } 3.6 \% \text { on } 50 \% \text { of the } \\
\text { market value }\end{array}$ & $\begin{array}{l}\text { Regressive tax at } 4 \% \text { up to market value } \\
\text { of } 1 \text { billion HUF, } 2 \% \text { above, with } \\
\text { maximum tax due of } 200 \text { million HUF }\end{array}$ & $\begin{array}{l}\text { Flat tax at } 18 \% \text {, lower rate of } 9 \% \text { applies to real estate } \\
\text { property, lineal heirs and spouses are fully exempt }\end{array}$ & \\
\hline Ireland & $\begin{array}{l}\text { Flat charge of between EUR90 for properties of maximum } \\
\text { EUR100,000 and EUR1,755 for properties between } \\
\text { EUR950,000 and EUR } 1 \text { million (i.e. tax rate of } 0.18 \% \text { is } \\
\text { applied to midpoint of value bands) } \\
\text { A progressive tax applies to properties over } 1 \text { million euro: } \\
0.18 \% \text { on the first } 1 \text { million euro and } 0.25 \% \text { above }\end{array}$ & $\begin{array}{l}\text { Stamp duty for residential buildings of } \\
1 \% \text { for amount up to EUR } 1 \text { million and } \\
2 \% \text { above, non-residential property } \\
\text { taxed at } 2 \%\end{array}$ & $\begin{array}{l}\text { Flat tax of } 33 \% \text { above tax-free threshold depending on } \\
\text { relationship between donor and beneficiary: } \\
\text { EUR310,000 for children, EUR32,500 for parents, } \\
\text { brothers, sisters and their partners and children, lineal } \\
\text { ancestors or descendants and EUR16,250 for others, } \\
\text { total exemption for spouses and partners, gifts are } \\
\text { exempted up to EUR3,000 }\end{array}$ & \\
\hline Italy & $\begin{array}{l}\text { Flat tax levied on revaluated cadastral value, rates } \\
\text { determined at municipal level with maximum } 1.06 \% \text {, main } \\
\text { residences are exempted }\end{array}$ & $\begin{array}{l}\text { - Registration Duty: between } 2 \% \text { (main } \\
\text { residence) and 9\% (other transactions) } \\
\text { - Mortgage Duty: fixed amount of EUR50 } \\
\text { - Cadastral Duty: fixed amount of EUR50 }\end{array}$ & $\begin{array}{l}\text { Flat tax at } 4 \% \text { for lineal heirs and spouses, at } 6 \% \text { for } \\
\text { siblings and other relatives and at } 8 \% \text { for non-relatives. } \\
\text { Allowances of EUR } 1,000,000 \text { for lineal heirs and } \\
\text { spouses and EUR100,000 for siblings. Real estate is } \\
\text { taxed on their revaluated cadastral value and multiplied } \\
\text { by a coefficient ( } 110 \text { for main residence, } 120 \text { for other } \\
\text { buildings) }\end{array}$ & $\begin{array}{l}\text { Specific net wealth tax: } \\
\text { Flat tax of } 0.2 \% \text { on bank } \\
\text { accounts and financial assets, } \\
\text { with minimum tax of EUR34.2 }\end{array}$ \\
\hline Luxembourg & $\begin{array}{l}\text { Flat tax levied on unitary value with rates between } 0.8 \% \\
\text { and } 1.5 \% \text { depending on type of real estate and a municipal } \\
\text { rate (for Luxembourg City between } 250 \% \text { and } 750 \% \\
\text { depending on type of property) }\end{array}$ & $\begin{array}{l}\text { Flat tax at } 6 \% \text { base rate and } 1 \% \\
\text { additional transcription fee, the } \\
\text { municipality of Luxembourg levies a } \\
\text { surtax of } 50 \% \text { on the transfer tax amount } \\
\text { (a deduction of EUR } 20,000 \text { per person } \\
\text { applies to the acquisition of a main } \\
\text { residence) }\end{array}$ & $\begin{array}{l}\text { Inheritances taxed through flat tax with rates between } \\
2.5 \% \text { and } 15 \% \text { depending on relationship between } \\
\text { donor and recipient and whether donors receive their } \\
\text { statutory share or more than this share (partners are } \\
\text { exempted and lineal heirs if receiving statutory share), } \\
\text { a progressive tax rate increase of } 1 / 10^{\text {th }} \text { to } 22 / 10^{\text {th }} \text { is } \\
\text { added for inheritances of more than EUR } 10,000\end{array}$ & \\
\hline
\end{tabular}




\begin{tabular}{|c|c|c|c|c|}
\hline & & & $\begin{array}{l}\text { Gifts taxed through flat tax with rates between } 1.8 \% \text { and } \\
14.4 \%\end{array}$ & \\
\hline Poland & $\begin{array}{l}\text { Flat tax levied on either size or value depending on type of } \\
\text { real estate, rates determined at the local level within } \\
\text { statutory limits, most importantly maximum PLN } 0.77 \text { per } \\
\mathrm{m}^{2} \text { for residential buildings and } 2 \% \text { for structures used to } \\
\text { conduct business activity }\end{array}$ & Flat tax of $2 \%$ & $\begin{array}{l}\text { Progressive tax with rates between } 3 \% \text { and } 20 \% \\
\text { depending on relationship between donor and recipient } \\
\text { (exemptions apply if no other taxable inheritance/gift } \\
\text { has been received from the same donor within a five- } \\
\text { year period) }\end{array}$ & \\
\hline Portugal & $\begin{array}{l}\text { Flat tax levied on cadastral value with } 0.8 \% \text { rate for rural } \\
\text { property, rates for urban property determined by } \\
\text { municipalities within statutory limits of } 0.3 \% \text { to } 0.5 \% \text { for } \\
\text { assessed urban property and between } 0.3 \% \text { and } 0.8 \% \text { for } \\
\text { unassessed property, tax rates for urban property are } \\
\text { tripled if vacant for more than a year }\end{array}$ & $\begin{array}{l}\text { Flat tax of } 5 \% \text { for rural properties, } \\
\text { progressive tax for urban properties with } \\
\text { rates between } 0 \% \text { and } 8 \% \text { for main } \\
\text { residences and between } 1 \% \text { and } 8 \% \text { for } \\
\text { second residences, an additional stamp } \\
\text { duty of } 0.8 \% \text { applies to register the } \\
\text { transfer } \\
\text { Registration of a mortgage is taxed with } \\
\text { rates between } 0.04 \% \text { and } 0.6 \% \\
\text { depending on duration of the mortgage }\end{array}$ & $\begin{array}{l}\text { No separate inheritance \& gift tax, but part of stamp } \\
\text { duty at } 10 \% \text { with additional } 0.8 \% \text { on gifts of immovable } \\
\text { property (partners and lineal heirs are exempt) }\end{array}$ & \\
\hline $\begin{array}{l}\text { Slovak } \\
\text { Republic }\end{array}$ & $\begin{array}{l}\text { - Land tax: flat tax of } 0.25 \% \text { levied on total value of land } \\
\text { (calculated as } \mathrm{m}^{2} \text { times applicable regional value of land } \\
\text { per } \mathrm{m}^{2} \text { ) } \\
\text { - Construction tax: flat tax of EUR0.033 per } \mathrm{m}^{2} \text { levied on } \\
\text { residential buildings and structural attachments to these } \\
\text { buildings (potential floor surcharge for multiple story } \\
\text { buildings of maximum EURO.33) } \\
\text { - Apartment tax: flat tax of EUR0.033 per } \mathrm{m}^{2} \text { levied on } \\
\text { apartments and non-residential buildings }\end{array}$ & $\begin{array}{l}\text { No separate real estate transfer tax, but } \\
\text { stamp duty applies to register change of } \\
\text { ownership equal to EUR66 or EUR33 if } \\
\text { registration is submitted electronically }\end{array}$ & & \\
\hline Slovenia & $\begin{array}{l}\text { - Charge for the use of building land: charge determined by } \\
\text { municipalities, levied on vacant and build land } \\
\text { - Property tax: progressive tax with rates between } 0.1 \% \\
\text { and } 1 \% \text { for dwellings, between } 0.2 \% \text { and } 1.5 \% \text { for estate } \\
\text { used for recreational purposes and between } 0.15 \% \text { and } \\
1.25 \% \text { for real estate used for business purposes, } \\
\text { exemption for buildings of less than } 160 \mathrm{~m}^{2}\end{array}$ & Flat tax at $2 \%$ & $\begin{array}{l}\text { Progressive tax with rates between } 5 \% \text { to } 14 \% \text { for } \\
\text { parents, siblings and their descendants, between } 8 \% \\
\text { and } 17 \% \text { for grandparents and between } 12 \% \text { and } 39 \% \\
\text { for all others, partners and lineal heirs are exempted, } \\
\text { movable property is exempted if it does not exceed } \\
\text { EUR5,000 }\end{array}$ & \\
\hline Spain & $\begin{array}{l}\text { Flat tax levied on cadastral value, rates determined at } \\
\text { municipal level within statutory limits: between } 0.4 \% \text { and } \\
1.1 \% \text { for urban properties and between } 0.3 \% \text { and } 0.9 \% \text { for } \\
\text { rural properties }\end{array}$ & $\begin{array}{l}\text { Flat tax of } 8 \% \text { to } 10 \% \text { depending on } \\
\text { autonomous region } \\
1.5 \% \text { for registration of immovable }\end{array}$ & $\begin{array}{l}\text { Progressive tax with different schedules across } \\
\text { autonomous regions, in national legislation rates differ } \\
\text { between } 7.65 \% \text { and } 34 \% \text {, multiplier of between } 1 \text { and } \\
2.4 \text { added depending on relationship between donor }\end{array}$ & $\begin{array}{l}\text { General net wealth tax: } \\
\text { Progressive tax with rates } \\
\text { between } 0.2 \% \text { and } 2.5 \% \text { on } \\
\text { individual net wealth if above }\end{array}$ \\
\hline
\end{tabular}


for exempted until EUR300,000,

close relatives and EUR8,000 for further relatives and certain other assets also

other persons, main residence often exempted, some

certain other assets also
exempted), tax rates can be regions grant full tax credit

changed by autonomous

Source: Boone et al. (2019), Kuypers et al. (2020) 


\section{0 | DELSA/ELSA/WD/SEM(2021)4}

Table 3. Housing and savings related tax expenditures - 2017

\begin{tabular}{|c|c|c|c|c|}
\hline Country & Tax expenditure for family home & $\begin{array}{c}\text { Tax expenditure for other real estate } \\
\text { property }\end{array}$ & $\begin{array}{c}\text { Tax expenditure for private pension } \\
\text { savings }\end{array}$ & Tax expenditure for capital income \\
\hline Austria & $\begin{array}{l}\text { - Deduction of mortgage interests and } \\
\text { repayments of mortgages contracted } \\
\text { before } 2016 \\
\text { - Deduction of costs related to building a } \\
\text { new owner-occupied house build before } \\
2016 \\
\text { (a maximum is applied to the sum of } \\
\text { these deductions and the deduction for } \\
\text { private pension saving) }\end{array}$ & $\begin{array}{l}\text { Deduction of mortgage interests for } \\
\text { mortgages on real estate which is rented } \\
\text { out }\end{array}$ & $\begin{array}{l}\text { Deduction private pension contributions if } \\
\text { contract started before } 2016 \text { (maximum } \\
\text { applied to sum of mortgage interests \& } \\
\text { repayments, buildings costs and } \\
\text { contributions to private pension funds) }\end{array}$ & \\
\hline Belgium & \multicolumn{2}{|c|}{$\begin{array}{l}\text { Flemish Region: deduction of } 40 \% \text { of mortgage interests with maximum EUR1,520 } \\
\text { interests taken into account (increased by EUR760 during first } 10 \text { years of mortgage) } \\
\text { Walloon Region: deduction of EUR1,520, decreases when net taxable income above } \\
\text { EUR21,000: EUR1,520 - [(Income-21,000)*1.275] (halved after } 10 \text { years) }\end{array}$} & $\begin{array}{l}\text { Non-refundable credit of } 30 \% \text { of } \\
\text { contributions, with a maximum contributions } \\
\text { taken into account of EUR940 }\end{array}$ & $\begin{array}{l}\text { Interests on savings accounts } \\
\text { exceptionally taxed at } 15 \% \text { flat rate and } \\
\text { first EUR } 1,880 \text { of interests are tax exempt }\end{array}$ \\
\hline Estonia & $\begin{array}{l}\text { Deduction of mortgage interests of } \\
\text { maximum EUR300 (EUR600 for couples) }\end{array}$ & Deduction of $20 \%$ of rental income & $\begin{array}{l}\text { Deduction private pension contributions with } \\
\text { maximum } 15 \% \text { of taxable income or } \\
\text { EUR6,000 }\end{array}$ & Dividend income exempted from taxation \\
\hline Finland & Deduction of $45 \%$ of mortgage interests & & $\begin{array}{l}\text { Deduction for contributions paid to private } \\
\text { pension funds with maximum of EUR5,000 }\end{array}$ & $\begin{array}{l}\text { Deduction for } 15 \% \text { of listed dividends and } \\
75 \% \text { of unlisted dividends up to } \\
\text { EUR } 150,000 \text {. }\end{array}$ \\
\hline France & & & $\begin{array}{l}\text { Deduction of } 10 \% \text { of net earnings with } \\
\text { minimum of EUR3,923 and maximum } \\
\text { EUR31,382 }\end{array}$ & Deduction of $40 \%$ of dividends \\
\hline Germany & & $\begin{array}{l}\text { Deduction of mortgage interests for } \\
\text { mortgages on real estate which is rented } \\
\text { out, with maximum of rental income }\end{array}$ & $\begin{array}{l}\text { Riester: deduction of maximum EUR2,100 } \\
\text { Rürup: deduction of } 84 \% \text { with maximum } \\
\text { contributions taken into account of } \\
\text { EUR23,362 }\end{array}$ & $\begin{array}{l}\text { Deduction of EUR801 for capital income } \\
\text { (double for joint taxation) }\end{array}$ \\
\hline \multicolumn{5}{|l|}{ Greece } \\
\hline Hungary & & & $\begin{array}{l}\text { Credit for private pension contributions of } \\
20 \% \text { with a maximum of } 100,000 \text { HUF } \\
(130,000 \text { HUF for people who reach } \\
\text { statutory retirement age by } 2020)\end{array}$ & \\
\hline Ireland & $\begin{array}{l}\text { Tax relief at source of mortgage interests } \\
\text { during first } 7 \text { years of mortgage (taken out } \\
\text { until } 31 \text { December 2012). Different reliefs }\end{array}$ & $\begin{array}{l}\text { Deduction of } 75 \% \text { of mortgage interest for } \\
\text { mortgages on real estate which is rented } \\
\text { out for residential purposes and deduction }\end{array}$ & $\begin{array}{l}\text { Deduction private pension contributions with } \\
\text { maximum } 15 \% \text { of earned income for those } \\
\text { aged under } 30 \text { to } 40 \% \text { of earned income for }\end{array}$ & \\
\hline
\end{tabular}


DELSA/ELSA/WD/SEM(2021)4

\begin{tabular}{|c|c|c|c|c|}
\hline Country & Tax expenditure for family home & $\begin{array}{c}\text { Tax expenditure for other real estate } \\
\text { property }\end{array}$ & $\begin{array}{l}\text { Tax expenditure for private pension } \\
\text { savings }\end{array}$ & Tax expenditure for capital income \\
\hline & for first-time and non-first-time buyers & $\begin{array}{l}\text { of } 100 \% \text { if rented out for non-residential } \\
\text { purposes }\end{array}$ & $\begin{array}{l}\text { those aged } 60 \text { or more, the overall earnings } \\
\text { limit is EUR } 115,000\end{array}$ & \\
\hline Italy & $\begin{array}{l}\text { Non-refundable credit equal to } 19 \% \text { of } \\
\text { interest repayments with maximum } \\
\text { amount of interest considered of } \\
\text { EUR4,000 }\end{array}$ & $\begin{array}{l}\text { Deduction of } 5 \% \text { of rental income if taxed } \\
\text { progressively in PIT }\end{array}$ & $\begin{array}{l}\text { Deduction of private pension contributions } \\
\text { with maximum EUR5, } 165\end{array}$ & \\
\hline Luxembourg & $\begin{array}{l}\text { Deduction of mortgage interests of } \\
\text { maximum EUR2,000 per family member } \\
\text { for first } 5 \text { years of occupation, EUR } 1,500 \\
\text { for next } 5 \text { years and EUR } 1,000 \text { afterwards }\end{array}$ & Deduction of $35 \%$ of rental income & $\begin{array}{l}\text { Deduction private pension contributions of } \\
\text { maximum EUR3,200 }\end{array}$ & $\begin{array}{l}\text { Interests on savings accounts exempted if } \\
\text { below EUR250 }\end{array}$ \\
\hline Poland & & & $\begin{array}{l}\text { Credit for private pension contributions of } \\
\text { maximum 5,115.6PLN }\end{array}$ & \\
\hline Portugal & $\begin{array}{l}\text { Tax credit for mortgage repayment } \\
\text { (interest and capital) of } 15 \% \text { with } \\
\text { maximum of EUR296 (higher maximum } \\
\text { for people on low income) (only for } \\
\text { mortgages taken out before } 31 \text { December } \\
\text { 2011) }\end{array}$ & & $\begin{array}{l}\text { Credit for private pension contributions of } \\
20 \% \text { with maximum of EUR400 for those } \\
\text { younger than } 35 \text {, EUR350 for those } \\
\text { between } 35 \text { and } 50 \text { and EUR } 300 \text { for those } \\
\text { older than } 50\end{array}$ & \\
\hline Slovenia & & Deduction of $10 \%$ of rental income & $\begin{array}{l}\text { Deduction private pension contributions } \\
\text { maximum } 5.844 \% \text { of gross wage or } \\
\text { EUR2,819.09 }\end{array}$ & $\begin{array}{l}\text { Deduction of EUR1,000 of interests on } \\
\text { deposits }\end{array}$ \\
\hline Spain & $\begin{array}{l}\text { Non-refundable credit of } 15 \% \text { of interest } \\
\text { and capital repayments, with a maximum } \\
\text { taken in consideration of EUR9,040 (only } \\
\text { for mortgages taken out before } 1 / 1 / 2013 \text { ) }\end{array}$ & Deduction of $60 \%$ of rental income & $\begin{array}{l}\text { Deduction private pension contribution with } \\
\text { maximum EUR8,000 or } 30 \% \text { of net labour } \\
\text { income }\end{array}$ & \\
\hline
\end{tabular}

Notes: In line with OECD (2010) types of tax reliefs are defined as follows: an exemption refers to income components which are part of pre-tax income but should not be declared and hence are not part of taxable income, a deduction refers to an amount that is subtracted from pre-tax income and a credit refers to an amount subtracted from the tax liability.

Source: Boone et al. (2019) 


\section{2 | DELSA/ELSA/WD/SEM(2021)4}

Table 4. Asset tests in minimum income schemes - 2017

\begin{tabular}{|c|c|c|c|c|c|c|}
\hline & \multirow[t]{2}{*}{ Type } & \multicolumn{2}{|c|}{ Treatment of immovable property } & \multirow{2}{*}{$\begin{array}{l}\text { Treatment of movable } \\
\text { property } \\
\text { Savings }\end{array}$} & \multicolumn{2}{|c|}{$\begin{array}{l}\text { Treatment of in-kind elements of movable } \\
\text { property }\end{array}$} \\
\hline & & Family home & Other real property & & Vehicles & Goods \\
\hline Austria & $\begin{array}{l}\text { Disqualification } \\
\text { EUR4315.20 in Vienna }\end{array}$ & $\begin{array}{l}\text { Granting of benefits may be } \\
\text { subject to registration of the } \\
\text { claim of the social welfare } \\
\text { authority after } 6 \text { months }\end{array}$ & Needs to be sold & $\begin{array}{l}\text { Included above exempt } \\
\text { amount }\end{array}$ & $\begin{array}{l}\text { Included, important } \\
\text { exemptions }\end{array}$ & Exemptions \\
\hline Belgium & Fictional rate of return & \multicolumn{2}{|c|}{$\begin{array}{l}\text { Imputed rent (cadastral income) is included as income, subject to } \\
\text { certain exemptions }\end{array}$} & $\begin{array}{l}\text { Fictional income of } 6-10 \% \text { of } \\
\text { savings above }+/ \text {-EUR } 6000\end{array}$ & & \\
\hline Estonia & $\begin{array}{l}\text { Discretionary, municipality must } \\
\text { deem list of immovables and } \\
\text { movables sufficient to cope }\end{array}$ & Exempt & & Included & $\begin{array}{l}\text { Discretionary, must } \\
\text { be reported }\end{array}$ & Exemptions \\
\hline Finland & $\begin{array}{l}\text { Disqualification } \\
\text { Easily realizable assets are taken } \\
\text { into account. No formal threshold; } \\
\text { some discretion may be used. }\end{array}$ & Exempt & $\begin{array}{l}\text { Included; if not easily realizable, } \\
\text { support can be granted as a } \\
\text { loan }\end{array}$ & Included & & Exemptions \\
\hline France & $\begin{array}{l}\text { Flat rate evaluation of lifestyle in } \\
\text { case of discrepancy between } \\
\text { lifestyle and means declared. }\end{array}$ & & & & & \\
\hline Germany & $\begin{array}{l}\text { Disqualification } \\
\text { +/-EUR5000 }\end{array}$ & Exempt if appropriate size & Included (some exceptions) & $\begin{array}{l}\text { Included, certain state } \\
\text { pension capital exempt }\end{array}$ & $\begin{array}{l}\text { Included, important } \\
\text { exemptions }\end{array}$ & Exemptions \\
\hline Greece & $\begin{array}{l}\text { Disqualification } \\
\text { see specific amounts }\end{array}$ & \multicolumn{2}{|c|}{$\begin{array}{l}\text { Total taxable value of real property must not surpass EUR } 90000 \\
\text { (increases for dependents apply) }\end{array}$} & max. EUR4800 for a single & If value $<$ EUR6000 & $\begin{array}{l}\text { List of disqualifying } \\
\text { goods and services }\end{array}$ \\
\hline Hungary & $\begin{array}{l}\text { Disqualification } \\
\text { See specific amounts }\end{array}$ & exempt & $\begin{array}{l}\text { Disqualifies: } \\
\text { one piece of property (incl. } \\
\text { vehicles) should not exceed } \\
\text { EUR2697; all property combined } \\
\text { should be below EUR7913 }\end{array}$ & $\begin{array}{l}\text { Included, see limit real } \\
\text { property }\end{array}$ & $\begin{array}{l}\text { Included, important } \\
\text { exemptions }\end{array}$ & \\
\hline Ireland & Fictional rate of return & Exempt & Included on notional basis & $\begin{array}{l}\text { Amount higher than exempt } \\
\text { EUR5000 is included on } \\
\text { notional basis (assessed in } \\
\text { combination with real estate) }\end{array}$ & & \\
\hline Italy & $\begin{array}{l}\text { No minimum income scheme at } \\
\text { national level }\end{array}$ & & & & & \\
\hline Luxembourg & Fictional rate of return & \multicolumn{2}{|c|}{$\begin{array}{l}\text { Included, converted into a life annuity according to multipliers laid } \\
\text { down in law }\end{array}$} & $\begin{array}{l}\text { Included, converted in a life } \\
\text { annuity }\end{array}$ & & \\
\hline
\end{tabular}


DELSA/ELSA/WD/SEM(2021)4

\begin{tabular}{|c|c|c|c|c|c|c|}
\hline & \multirow[t]{2}{*}{ Type } & \multicolumn{2}{|c|}{ Treatment of immovable property } & \multirow{2}{*}{$\begin{array}{l}\text { Treatment of movable } \\
\text { property } \\
\text { Savings }\end{array}$} & \multicolumn{2}{|c|}{$\begin{array}{l}\text { Treatment of in-kind elements of movable } \\
\text { property }\end{array}$} \\
\hline & & Family home & Other real property & & Vehicles & Goods \\
\hline Poland & $\begin{array}{l}\text { Generally not taken into account, } \\
\text { unless flagrant disproportion with } \\
\text { income status }\end{array}$ & & & & & \\
\hline Portugal & Mixed & $\begin{array}{l}\text { Included at a fictional rate of } \\
\text { return of } 5 \% \text { only if its value > } \\
\text { an exempt EUR193 } 005 .\end{array}$ & $\begin{array}{l}\text { If no actual rents are earned, } 5 \% \\
\text { of its value is included as } \\
\text { income. }\end{array}$ & $\begin{array}{l}\text { Disqualifies if > } \\
\text { EUR25153.20, fictional rate of } \\
\text { return of } 5 \% \text { is taken into } \\
\text { account on top of actual } \\
\text { revenue }\end{array}$ & Included & \\
\hline $\begin{array}{l}\text { Slovak } \\
\text { Republic }\end{array}$ & Disqualification & Exempt & Included & Included & $\begin{array}{l}\text { Included, important } \\
\text { exemptions }\end{array}$ & Exemptions \\
\hline Slovenia & Disqualification & $\begin{array}{l}\text { Exempt, up to the value of an } \\
\text { appropriate apartment set by } \\
\text { law }\end{array}$ & $\begin{array}{l}\text { Included, certain types of gainful } \\
\text { property are exempt }\end{array}$ & $\begin{array}{l}\text { Certain amounts and } \\
\text { pensions savings are exempt. } \\
\text { Included. }\end{array}$ & $\begin{array}{l}\text { Included, important } \\
\text { exemptions }\end{array}$ & Exemptions \\
\hline Spain & $\begin{array}{l}\text { No minimum income scheme at } \\
\text { national level }\end{array}$ & & & & & \\
\hline
\end{tabular}

Source: Marchal et al. (2020 forthcoming), compiled based on MISSOC (2017)

Table 5. Asset tests in other benefit schemes (only ones which are included in simulations) - 2017

\begin{tabular}{l|l}
\hline \multicolumn{1}{c}{ Country } & \multicolumn{2}{c}{$\begin{array}{l}\text { Pensioners housing allowance: } 8 \% \text { of net wealth (assets } \\
\text { minus debt) above a threshold (EUR16,400 for } \\
\text { singles/EUR26,240 for couples) is taken into account in the } \\
\text { means-test, exemptions apply to the value of the main } \\
\text { residence and EUR2,000 for deposits }\end{array}$} \\
\hline Germany & $\begin{array}{l}\text { Education benefit: wealth holdings, after taking into account } \\
\text { allowances, are subtracted from the benefit amount. } \\
\text { Allowances are equal to EUR7,500 for singles, EUR7,000 for } \\
\text { married couples, increased with EUR2,100 for each child } \\
\text { (household furniture is not taken into account, but value of } \\
\text { family home and vehicles are taken into account) }\end{array}$ \\
\hline Ireland & $\begin{array}{l}\text { Asset test described in Table } 4 \text { applies to all non-contributory } \\
\text { benefits }\end{array}$ \\
\hline
\end{tabular}

Source: Boone et al. (2019) 


\section{Data and methods}

30. Comprehensive figures on the distribution of wealth have long lagged behind those for the distribution of income. The main reason for this is the difficulty of gathering data covering the wealth holdings of all population groups (particularly at the top) and at the same time of all possible wealth components. In the currently rapidly expanding literature many different data sources have been exhausted to estimate as accurately as possible the distribution and inequality of wealth (i.e. surveys, wealth registers, tax data, estate data, rich lists, financial leaks, ...). In this paper we do not aim to provide figures for the actual level of inequality, but rather focus on the difference in the distribution before and after taxes and transfers. In doing so, we rely only on survey data. Although they are known to not cover the top of the income and wealth distributions sufficiently well (see e.g. Bach et al. (2019) and Vermeulen (2018)) they are the only source that also provides auxiliary information necessary to determine jointly liabilities for taxes and contributions and benefit entitlements. Since tax avoidance and evasion is typically large at the top of the income and wealth distributions (see e.g. Johns \& Slemrod (2010) and Alstadsæter et al. (2019)) our simulations based on survey data alone likely cover the bulk of actual tax payments taking place. ${ }^{16}$ The inequality figures cited in this paper should be regarded as a lower limit.

31. While good-quality, comparable survey data on household wealth have long been lacking, several new initiatives have been introduced over the last two decades. The main data sources used are currently the Luxembourg Wealth Study (LWS) and the Eurosystem Household Finance and Consumption Survey (HFCS). While the first applies ex-post harmonization to national wealth surveys from 16 countries across the world, the latter starts from an ex-ante harmonized survey conducted in the countries of the Euro Area. Information on net wealth is also observed in the Survey of Health, Ageing and Retirement (SHARE), but this survey only covers the population aged 50 years and over. The OECD's Wealth Distribution Database (WDD) brings together aggregate statistics from several administrative data, national wealth surveys as well as those from the HFCS.

32. In this paper we make use of data from the second wave of the HFCS which was collected around the year 2014. The survey covers detailed information on household wealth together with sociodemographics, gross incomes and other information relevant for the simulation of taxes and benefits. Net wealth is defined as the sum of real and financial assets less liabilities, where real assets include real estate, self-employment business assets, vehicles and valuables, financial assets refer to deposits, shares, bonds, private pension savings, etc., while for liabilities both mortgage and non-mortgage debt are taken into account. Importantly, entitlement rights to public and occupational pensions and social insurance benefits are not included in the HFCS definition of household wealth. Income is for most countries only covered gross of taxes ${ }^{17}$ and includes employment income, self-employment income, financial income from investments and closely held businesses, rental income, public and private pensions, public and

\footnotetext{
16 The simulated revenues from the wealth-related taxes were validated against the OECD revenue statistics (see Boone et al. (2019)). This shows that the wealth taxes most target at the rich such as the net wealth taxes of France and Spain are already oversimulated based on the survey data alone, any correction for the top of the distribution would increase the oversimulation.

17 In the core variable list of the HFCS only gross incomes are available. For Italy and Poland the non-core variable list includes information on net incomes. The way in which the incomes were collected differs. In Italy net incomes were collected and gross incomes are estimated based on legislative and institutional parameters. In Germany, Greece, Poland and Portugal respondents could choose to provide net or gross amounts for all income components, in Belgium and Austria only for certain income components. In other countries administrative data are used: registers in Finland and partially in Ireland, financial intermediaries in Estonia and tax files in France (Eurosystem Household Finance and Consumption Network (HFCN), 2016).
} 
private transfers ${ }^{18}$ and other types of income. The income reference period for the second wave data is mostly 2013, it is 2014 for France, Italy and Hungary, 2012 for Estonia, Portugal and Ireland and 2010 for Spain. ${ }^{19}$ The values for net wealth generally refer to the moment of the interview or the last day of the income reference period. The HFCS applies an oversampling strategy to get a better coverage of the top of the distribution (except for Finland, Italy and Ireland) (Eurosystem Household Finance and Consumption Network (HFCN), 2016).

33. The HFCS data were adapted for use in EUROMOD, the EU-wide tax-benefit microsimulation model. ${ }^{20}$ EUROMOD takes information on market incomes and other relevant information from an underlying database in order to simulate non-contributory cash benefit entitlements and liabilities for direct taxes and social-insurance contributions based on the tax-benefit rules in place (Sutherland \& Figari, 2013). EUROMOD usually runs on EU-SILC data, but using the HFCS as input data provides the opportunity to enrich the scope of simulations in EUROMOD with simulations of wealth-related policies, i.e. taxes on wealth and wealth transfers, tax reliefs related to wealth and asset tests in determining benefit eligibility. This is not possible based on EU-SILC as it does not cover sufficient information on assets and liabilities.

34. The combination of HFCS and EUROMOD allows to simulate most of the wealth-related policies described in Section 2. alongside cash benefit entitlements and personal income tax and social-insurance contribution liabilities. The most recent year for which this infrastructure is developed concerns the taxbenefit policies of 2017. Details are described in Boone et al. (2019). A few caveats need to be kept in mind which are described in Annex A. Since we simulate policies of 2017, we uprate income and wealth variables from their reference period to the price level of 2017. The income variables are uprated with the indicators supplied in the standard version of EUROMOD, while the wealth variables are uprated with information on their corresponding categories in the national accounts (see Boone et al., (2019) for details). ${ }^{21}$ The HFCS data are supplied in five imputations to deal with the issue of item non-response (Eurosystem Household Finance and Consumption Network (HFCN), 2016). In order to exploit this to the fullest we create five HFCS input datasets to be run through EUROMOD. The results presented in this paper reflect the mean over the five imputations.

35. Like other micro-simulation analyses of the redistributive effects of taxes and benefits (Decoster \& Van Camp, 2001; Piketty \& Saez, 2007; Verbist \& Figari, 2014) only their direct impact is analysed. Hence, indirect redistribution for instance through behavioural reactions (Bergh, 2005), macro-economic shocks, tax evasion, income shifting ${ }^{22}$ or benefit non-take-up is not considered. Furthermore, we only focus on cash redistribution and exclude in-kind benefits which can be important parts of the redistributive process (Verbist, Förster, \& Vaalavuo, 2012). Finally, we take a cross-sectional view on redistribution, although the

\footnotetext{
18 When the simulated transfers are higher than the reported ones in HFCS we use the simulated ones.

19 In the new release of the HFCS data in March 2020, the Spanish wave with income reference period 2010 was moved to the first wave and replaced by results with income reference period 2014. Our databases were constructed on a previous version of the second wave data.

20 Another option would have been to match information on assets and debts from the HFCS to the standard EUROMOD input database which is based on EU-SILC. However, we chose to work with the full HFCS database because it covers the top of the distribution better than EU-SILC. Validations show that simulated disposable incomes are very similar for HFCS and EU-SILC throughout the distribution, except at the top where disposable incomes are larger for HFCS than for EU-SILC (Boone, Derboven, Figari, Kuypers, \& Verbist, 2019).

21 Although categories of the national accounts and HFCS do not always coincide perfectly (Kavonius \& Honkkila, 2013; Waltl, 2020), they are the best available information to take into account the evolution of assets and debt.

22 Tax payers could for instance shift or disguise labour income as capital income or capital income as capital gains to avoid larger tax liabilities.
} 
main goal of certain instruments such as pensions is redistribution across the life-cycle rather than between poor and rich.

36. This paper compares redistributive effects as calculated traditionally in the literature by assessing taxes and benefits against the distribution of income with a broader framework which also accounts for the distribution of wealth. The latter is constructed by annuitising net wealth and adding it to income following the approach proposed by Weisbrod \& Hansen (1968). The following formula is used to derive the concept of income and annuitised net wealth:

$$
\begin{gathered}
A Y=Y+\left[\frac{\rho}{1-(1+\rho)^{-n}}\right] * N W \\
n=T \text { for singles, } T_{1}+\left(T-T_{1}\right) * b \text { for couples }
\end{gathered}
$$

37. In this formula $A Y$ refers to the income plus annuitised net wealth, $Y$ equals income received from employment, self-employment, public, occupational and private pensions ${ }^{23}$, public and private transfers and other income sources. Note that capital and rental income are not included since we now convert wealth into an annuity. $N W$ is net wealth (i.e. assets minus liabilities) and $\rho$ is the interest rate of the annuity. $n$ captures the length of the annuity, which is approximated by the life expectancy at the age of the given person, by country and gender. $T$ refers to the life expectancy of singles or the longest living partner of a couple, $T_{1}$ refers to the life expectancy of the shortest living partner of a couple. ${ }^{24}$ As mentioned before, we equivalise both income and wealth using the OECD modified scale, with $b$ being the reduction in equivalence scale after the death of the first partner of the couple. ${ }^{25}$

38. Following Kuypers et al. (2019), we define pre-tax and post-tax concepts of annuitised net wealth in order to assess the redistributive effect of wealth-related taxation. This means we assume wealth-related taxes to lower the amount of their tax base instead of being paid out of income. In particular, we take into account event wealth taxes payable in the policy year (2017) (i.e. real estate transfer taxes and inheritance and gift taxes) by subtracting them from the stock of net wealth $(N W)$ which is subjected to the annuity formula. ${ }^{26}$ We take into account yearly recurrent wealth taxes (i.e. real property taxes and net wealth taxes) by applying different interest rates $(\rho)$ in the annuity formula, hence assuming that these taxes will be paid until death. For the pre-tax concept of net wealth (i.e. gross annuitised net wealth) we use a $5 \%$ interest rate for everyone (long-term pre-tax interest rate assumed in Piketty (2014)). Of course the pre-tax rate of return differs substantially in practice (e.g. wealthier people tend to achieve higher rates of return (Piketty, 2014; Fagereng, Guiso, Malacrino, \& Pistaferri, 2020)). We do not take this into account as it would make the calculation of the annuity more cumbersome and less transparent. Moreover, for the analyses shown here the difference between the pre-tax and post-tax interest rates is more important than their actual

\footnotetext{
${ }^{23}$ As long as individuals are not retired private pension savings are counted as net wealth and hence turned into an annuity. Once individuals retire private pension savings are received as a stream which is considered as income.

${ }^{24}$ Relying on life expectancies implies that no bequests are assumed. The wealth annuity should be viewed as a financial resource that is at the disposal of their owner(s) in case of need, not as actual consumption levels. Therefore, we deem it relevant to take into account all wealth. Of course the wealth annuity can be easily adapted to take into account bequests. Yet, as bequests are typically larger at the top of the distribution this would result in a substantial decrease in joint income-wealth inequality levels.

25 Because we use the OECD modified equivalence scale $b$ is always equal to 0.5 .

${ }^{26}$ Event wealth taxes are only simulated when households report an event such as the purchase of a house or the receipt of an inheritance or gift in 2017 (since we uprate to 2017 in practice this means we take the events from the income reference period in the second wave). The amounts of inheritances and gifts are reported gross of taxes in the separate HFCS variables, while they are included net of taxes in the total net wealth variable (as the total wealth variable refers to the moment of interview or the last day of the income reference period, the taxes have already been paid). Therefore, we simulate in EUROMOD inheritance and gift taxes based on the gross amounts. The tax liabilities are then added to net wealth to obtain gross wealth.
} 
levels. Taking into account higher rates of return for wealthier people would increase joint income-wealth inequality levels, so again our figures on inequality levels should be viewed as a bottom line. For the posttax concept of net wealth (i.e. net annuitised net wealth) we simulate for each household the interest rate as a function of the recurrent wealth taxes they pay. In some countries there is hardly any difference to the gross interest rate (Austria, Luxembourg, Slovenia), whereas in others the net interest rate is less than $4.5 \%$ (Estonia, Italy, Poland). The net interest rate in Hungary is also $5 \%$ as we only simulate event wealth taxes.

39. Figure 4 describes the redistributive process in the income and the joint income-wealth frameworks. The top part shows the process as studied traditionally in the literature. Usually, the starting point (i.e. pre-transfer pre-tax concept) is market income consisting of income from employment, selfemployment, capital, real estate, private (and occupational) pensions, private transfers and other income. However, several studies have criticised this approach for cross-country comparisons arguing that it does not take into account the potential effects of differing public old-age pension provision. Pre-transfer inequality and the redistributive effect may therefore be artificially high in countries with comprehensive old-age public pension systems (Bradley, Huber, Moller, Nielsen, \& Stephens, 2003; Jesuit \& Mahler, 2010). One solution to this problem is to treat public pensions as part of the pre-transfer concept rather than as a transfer. ${ }^{27}$ The two approaches (i.e. with and without public pensions in the pre-transfer concept) can then be considered as a lower and upper bound of the redistributive capacity of the tax-transfer system. Another option would be to exclude the elderly from the analysis, as is generally done in OECD publications (Causa \& Hermansen, 2019; Immervoll \& Richardson, 2011). We take the first option as the benchmark for which the results are shown in Section 5 . Results for the elderly and non-elderly separately considering pensions as part of the pre-transfer concept are shown in Section 7, while the results for including only market income in the pre-transfer concept (for the total population as well as for the elderly and non-elderly separately) are presented in Annex B. The step towards disposable income (i.e. post-tax post-transfer concept) then entails adding public transfers and subtracting social-insurance contributions and liabilities for personal income and capital income taxes In addition, also liabilities for wealth-related taxes are subtracted, which is not always done in previous studies. Negative incomes are treated according to the OECD guidelines (OECD, 2017). However, negative incomes as a consequence of the inclusion of wealthrelated taxes are not treated as it would bias the comparison with the joint income-wealth framework.

40. In the joint income-wealth framework the pre-transfer pre-tax concept refers to the sum of market income (\& pension income) (excluding capital and rental income, see above) and gross annuitised net wealth, while the post-transfer post-tax concept is the sum of disposable income (again excluding capital and rental income) and net annuitised net wealth. Negative annuitised net wealth is the result of higher debt than assets, so this is kept as a negative amount in the data. ${ }^{28}$ The difference between the two concepts reflects as in the traditional income framework the addition of public transfers and the subtraction of social insurance contributions and liabilities to the personal income and capital income tax. This framework also accounts for the difference between gross and net annuitised net wealth. Subtracting event wealth taxes from annuitised wealth corresponds to multiplying the taxes with the net annuity formula. The impact of recurrent wealth taxes is equal to gross annuitized wealth multiplied with the difference between the gross and net annuity formula.

\footnotetext{
${ }^{27}$ In this case we treat only the old-age pensions as market income. Survivors, disability and early retirement benefits and old-age social assistance are still considered as transfers.

${ }^{28}$ Between $1.8 \%$ of households in Italy and $12.4 \%$ in Ireland have negative net wealth (HFCN, 2016).
} 
Figure 4. The redistributive process in the two frameworks

Income framework

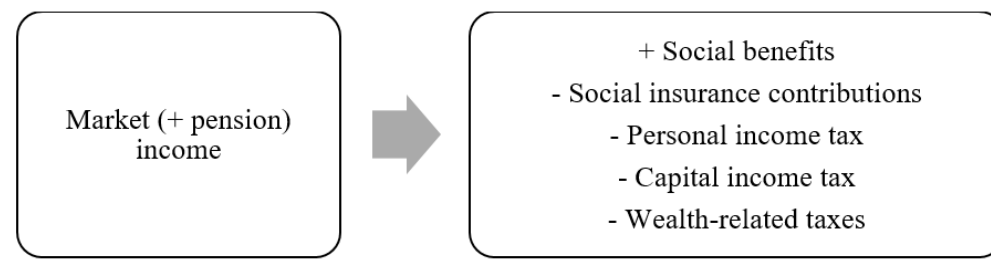

Joint income-wealth framework
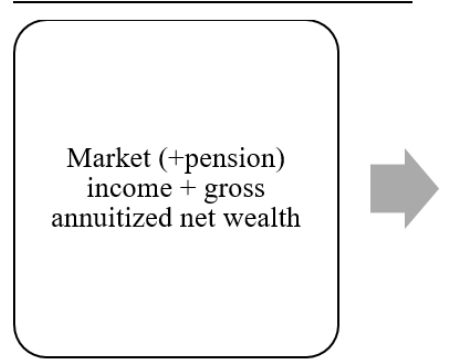
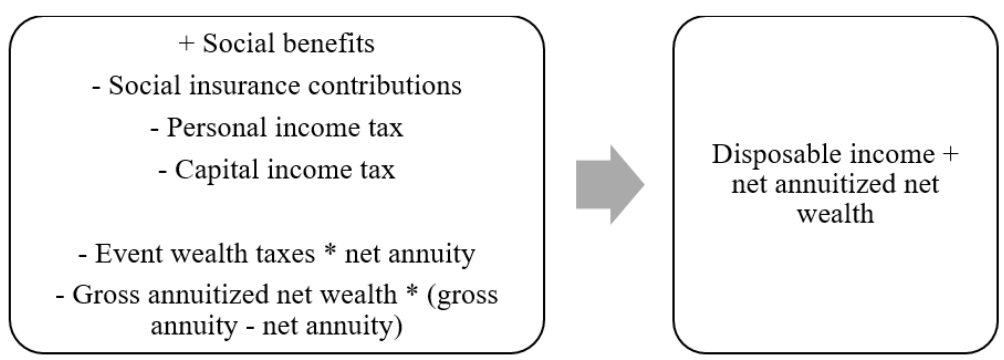

Source: Kuypers et al. (2019)

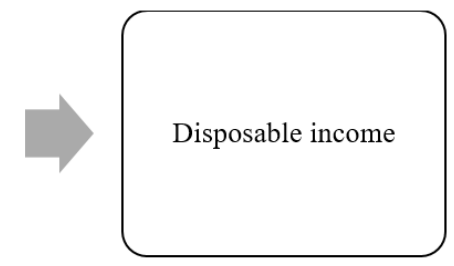

41. The association between people's position in the distributions of disposable income and disposable income plus annuitised net wealth is stronger than that observed earlier between disposable income and net wealth, as one would expect. In particular, we observe a higher rank correlation (Figure 5 vs. Figure 1), and a greater share of people are in the same quartiles of both distributions (Figure 6 vs. Figure 2). However, also the association between disposable income and disposable income plus annuitised net wealth is not perfect. On average about $60 \%$ of people remain in the same quartile when net annuitized net wealth is added: about $19 \%$ in the first quartile of both distributions, $13 \%$ in the second, $12 \%$ in the third and $18 \%$ in the top quartile (Figure 6). Hence, $40 \%$ change quartile if their net annuitised net wealth is accounted for. Again, we find more correlation at the bottom and the top than in the middle. Rank correlation between income and joint income-net wealth is lowest for Belgium and Poland (Figure 5), although even in these countries more than half of the people remain in the same quartile. Rank correlation is highest for Estonia, Greece and France.

42. The countries with high (low) rank correlation between income and wealth (Figure 1) are not necessarily the same with high (low) rank correlation between income and joint income-wealth (Figure 5). This is, because annuitised wealth also depends on the correlation between wealth and age as life expectancy is used in its calculation. For two households with the same income and wealth, annuitised wealth is higher for older than for younger households. Older households are therefore more likely to be re-ranked when accounting for annuitised wealth. In countries where pensions are relatively low compared to working-age incomes and wealth is mainly owned by the elderly (such as in Belgium) rank correlation between income and joint income-wealth is low. In contrast, Greece, for instance, combines low rank correlation between income and wealth with very high rank correlation between income and joint incomewealth. This is mainly due to pensions being relatively high compared to working-age income and net wealth is highest for 45-54 year-olds. In the annuitisation pensioners' wealth receives a greater weight than working-age people's wealth such that correlation increases. 
Figure 5. Rank correlation between equivalised disposable income and equivalised disposable income plus net annuitised net wealth - 2017

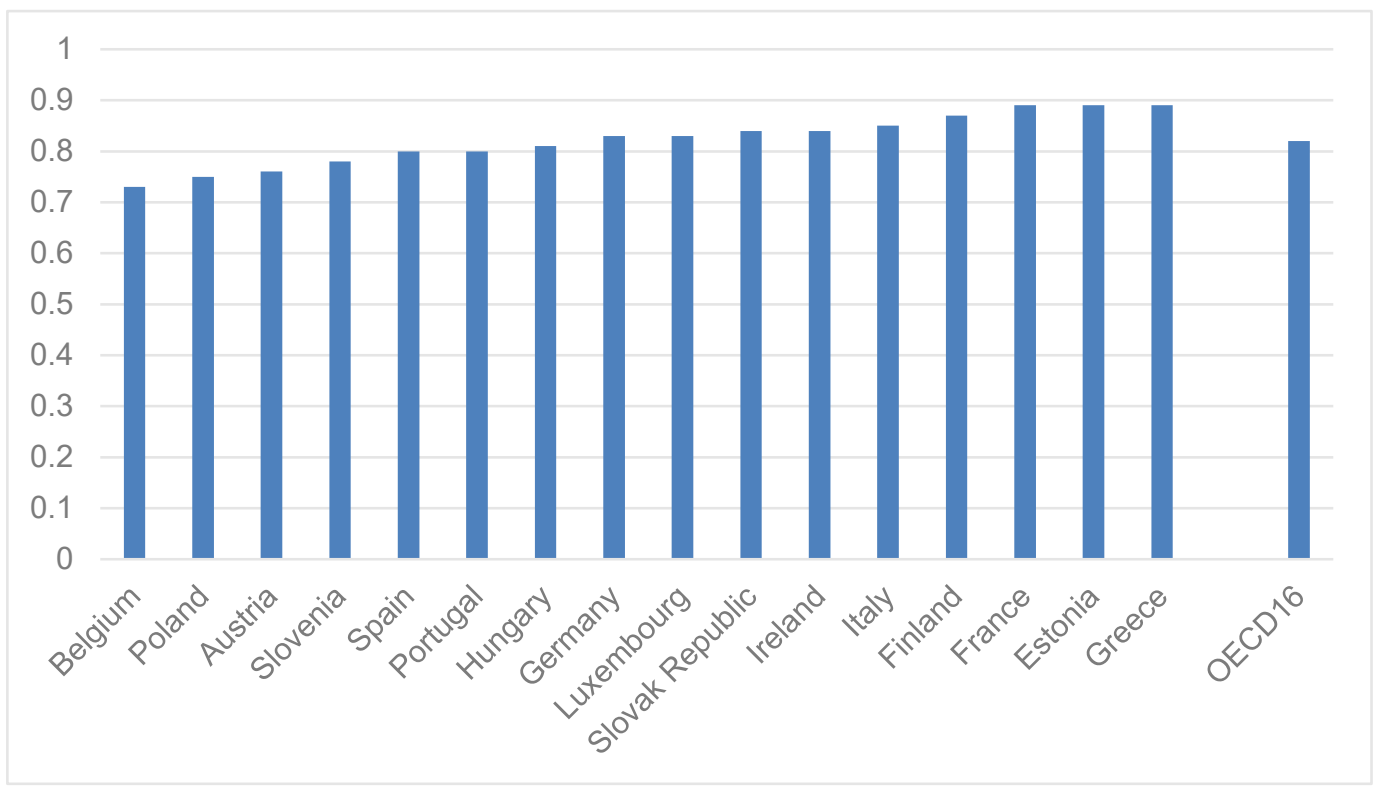

Source: Authors' calculations based on HFCS wave 2 and EUROMOD

Figure 6. The distribution of individuals across quartiles of equivalised disposable income and equivalised disposable income plus net annuitised net wealth - OECD average - 2017

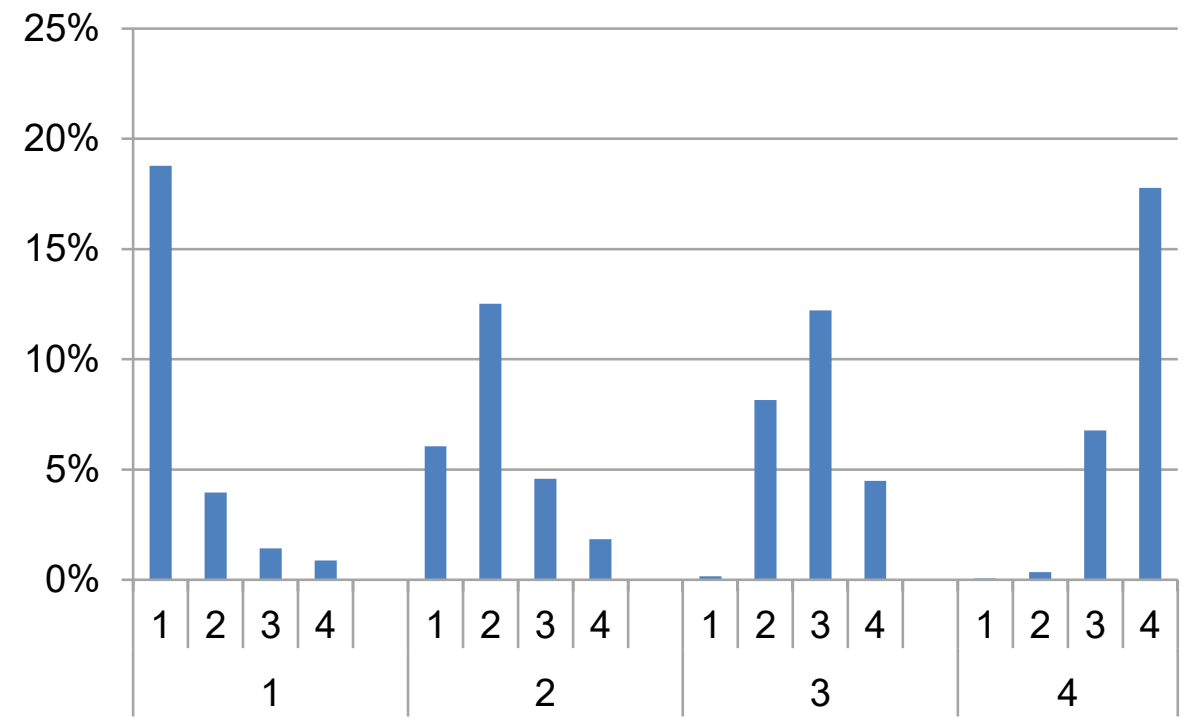

Note: Bottom number refers to income quartile, top number to quartile of income plus net annuitised net wealth. Source: Authors' calculations based on HFCS wave 2 and EUROMOD. 


\section{The redistributive effects of tax-benefit systems in from joint income-wealth perspective}

43. We define the redistributive effects (RE) of tax-benefit systems as the difference between a 'preGini' (i.e. inequality before taxes and transfers) and a 'post-Gini' (i.e. inequality after taxes and transfers). In order to facilitate cross-country comparisons, we also show the redistributive effects in relative terms (i.e. as a percentage of the 'pre-Gini'). As mentioned in Section 3. , we show redistributive effects relative to market and pension incomes (MPI) in the main text as well as relative to market incomes alone (MI) in Annex B. Section 7 shows results obtained when excluding the elderly.

44. The absolute redistributive effect in the income framework (INC) is given by the difference between the Gini coefficient of market income (or market and pension income) and the Gini coefficient of disposable income (with wealth-related taxes subtracted):

$$
\text { Absolute } R E_{I N C}=\operatorname{Gini}_{M(P) I}-\operatorname{Gini}_{D I} .
$$

45. In the joint income-wealth framework (INC-NW), the value of annuitised wealth gross of wealthrelated taxes (GAW) is added to calculate the 'pre-Gini', while the value of annuitised wealth net of wealthrelated taxes (NAW) is added to calculate the 'post-Gini':

$$
\text { Absolute } R E_{I N C-N W}=\operatorname{Gini}_{M(P) I+G A W}-G_{i n i} i_{D I+N A W} \text {. }
$$

46. Figure 7 shows the redistributive effects in the two frameworks using market and pension income (plus gross annuitised net wealth) as starting point. Panel A gives absolute and relative redistributive effects as calculated in the traditional income framework and Panel B when our proposed joint incomewealth framework is used.

47. Gini coefficients before redistribution as measured in terms of market and pension income, presented by the black horizontal line, range between 0.498 in Ireland and 0.292 in Austria (Panel A). Gini coefficients after redistribution, which are presented by the blue bar, lie between 0.403 in Estonia and 0.203 in Austria. In this framework redistribution results in a decrease of inequality by on average about $25 \%$ ( 0.099 absolute Gini points). Absolute redistributive effects, presented by the grey bar, are high for Ireland (0.148) and low for Poland (0.057), Greece (0.058) and Spain (0.058). In relative terms, presented by the diamond, Finnish taxes and benefits are the most redistributive ones (37.2\%) and Spanish ones the least $(13 \%)$.

48. In the joint income-wealth framework, Gini coefficients before redistribution range from 0.486 in Ireland to 0.332 in Greece and Slovak Republic (Panel B). After redistribution they vary from 0.428 in Spain to 0.262 in Finland. Redistribution reduces inequality measured in the joint income-wealth framework by on average about $14 \%$, or 0.057 absolute Gini points. Absolute redistributive effects are highest in Finland $(0.102)$ and lowest in Austria (0.030), while relative effects are highest in Finland (28\%) and lowest in Spain $(6.7 \%)$.

49. Comparing the two panels of Figure 7 indicates important differences between the two frameworks:

- Including gross annuitised net wealth has a (slightly) equalising effect on inequality before redistribution in Poland, Greece, Estonia, Slovak Republic and Ireland, little effect in Finland, Hungary and Slovenia, and a disequalising impact in the other countries.

- Gini coefficients after redistribution are usually higher when net annuitised net wealth is taken into account, most strongly so in Austria and Luxembourg. Exceptions are Poland, Greece and Estonia, where there is hardly any difference in the Gini coefficient of disposable income and the Gini coefficient of the sum of disposable income and net annuitised net wealth. In Estonia and Greece, rank correlation between income and joint income-wealth is very high (see Figure 5) such that there is hardly any reranking and hence hardly any effect on inequality. Rank correlation is considerably 
lower for Poland, with reranking relatively high in the lowest income quartile (i.e. inequalityreducing) but low in the highest income quartile (i.e. inequality-increasing). These two effects seem to cancel each other out.

- When annuitised net wealth is taken into account the tax-benefit system is still redistributive, but to a lesser extent than when assessed only against the income distribution. In the majority of countries both the absolute and relative redistributive effects in the joint income-wealth framework are more or less half that of the redistributive effects in the traditional income framework. The strongest decreases in the redistributive effects are found in Austria and Luxembourg (60 to $70 \%$ lower redistribution when annuitised net wealth is taken into account). In Estonia, Poland and Greece the redistributive effect decreases the least (less than $30 \%$ lower redistributive effect when annuitised net wealth is accounted for).

50. Figure 8 compares the relative redistributive effects in the two frameworks against each other. Overall we can distinguish three groups of countries. The largest group of countries (Poland, Estonia, Greece, Hungary, Spain, Italy, Portugal) have below average redistributive effects in both the joint incomewealth and the income framework. Another group consisting of Finland, Ireland, France, Slovak Republic, Slovenia and Belgium achieve above average redistribution in both frameworks. Finally, Germany, Luxembourg and Austria redistribute above average when assessed in the traditional income framework, but redistribution is below average when annuitised net wealth is taken into account.

51. When using the more restricted pre-transfer concepts (not including public pensions) redistribution in the joint income-wealth framework is also considerably lower than in the income only framework. The results starting from market income (plus gross annuitized net wealth) are shown in Figure B.1. In the income framework Gini coefficients before redistribution range between 0.540 in Portugal to 0.371 in Finland, with a cross-country average of 0.501 . In the joint income-wealth framework the Gini coefficients before redistribution vary between 0.511 in Germany to 0.366 in Finland, with a cross-country average Gini of 0.452 . In all countries inequality before redistribution is higher in the income framework than in the joint income-wealth framework when starting from market income alone. As we will explain below this is mainly driven by the elderly as market income is very unevenly spread between them (as most of them do not work), while most elderly have relatively high wealth. Including wealth then has an equalising effect. Gini coefficients after redistribution remain the same as in Figure 7 such that absolute redistributive effects are on average equal to $0.095(21.4 \%$ in relative terms) in the joint income-wealth framework and 0.198 $(39.7 \%)$ in the income framework. Hence, as expected inequality before taxes and transfers and the redistributive effect is larger in both frameworks when public pensions are considered as a redistributive instrument rather than as postponed market income. In line with the figures from the OECD's Income Distribution Database (IDD) redistribution in the income framework starting from market income alone is high in Slovenia, France, Belgium and Austria, while it is low in Estonia and Spain (Causa \& Hermansen, 2019). ${ }^{29}$

\footnotetext{
${ }^{29}$ For a few countries, there are some discrepancies with the results from the IDD. For instance, Ireland records the highest relative redistributive effect in the IDD, but the fourth lowest in our analysis of market income including pensions and about average in the analysis of market income. Differences can be due to different sampling frames in the underlying databases (oversampling in the HFCS), or differences in the definition of income and its components
} 
Figure 7. The redistributive effects of tax-benefit systems relative to market plus pension income, overall population - 2017

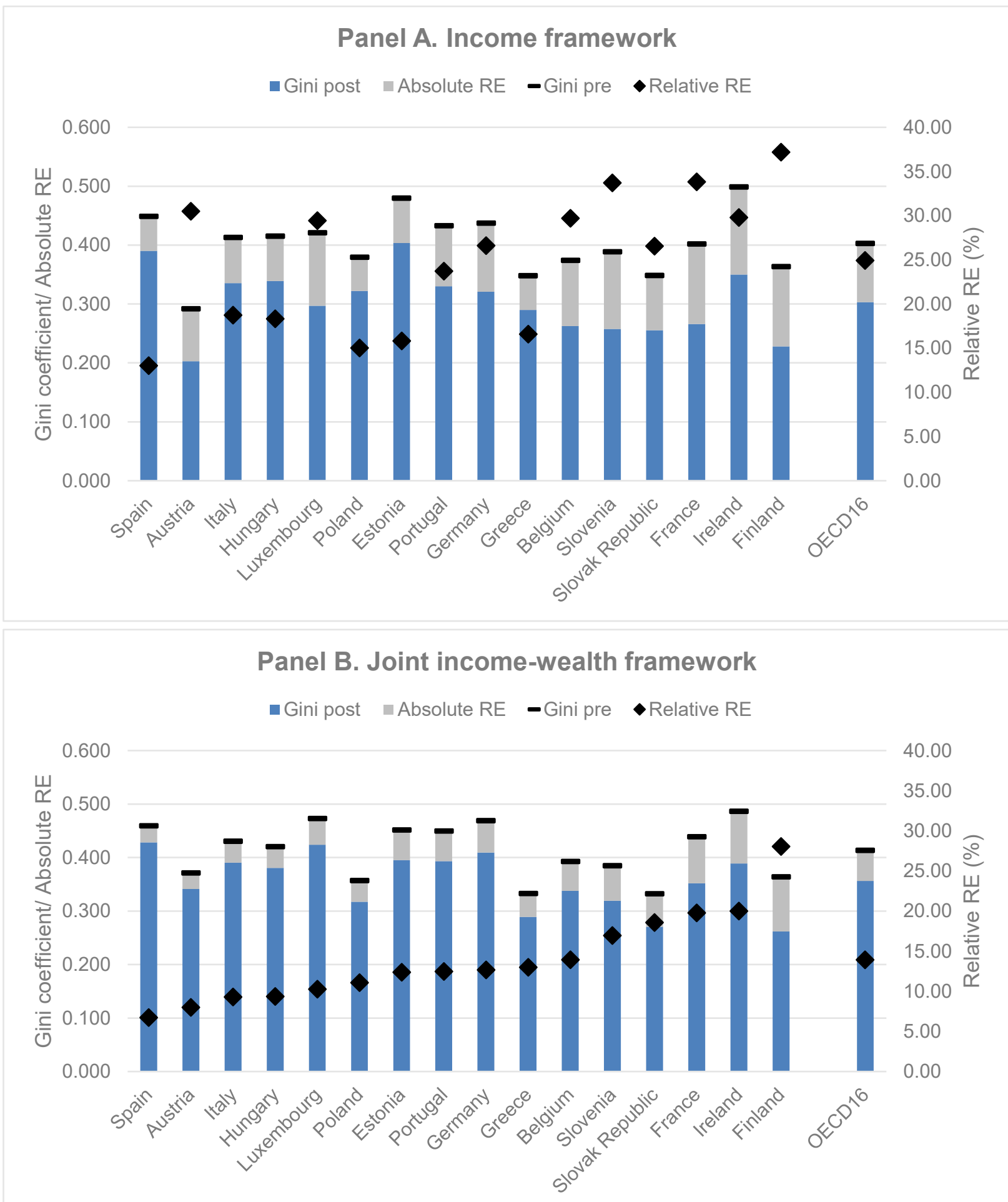

Notes: RE=redistributive effect. Gini post refers to the Gini coefficient after redistribution, which is the Gini of disposable income in the income framework and the Gini of disposable income plus net annuitised net wealth in the joint income-wealth framework. Gini pre refers to the Gini coefficient before redistribution, which is in this figure the Gini of market \& pension income in the income framework and the Gini of market \& pension income plus gross annuitised net wealth in the joint income-wealth framework. Countries are ranked in ascending order of the relative redistributive effect in the joint income-wealth framework.

Source: Authors' calculations based on HFCS wave 2 and EUROMOD. 
Figure 8. Relative redistributive effects in two frameworks

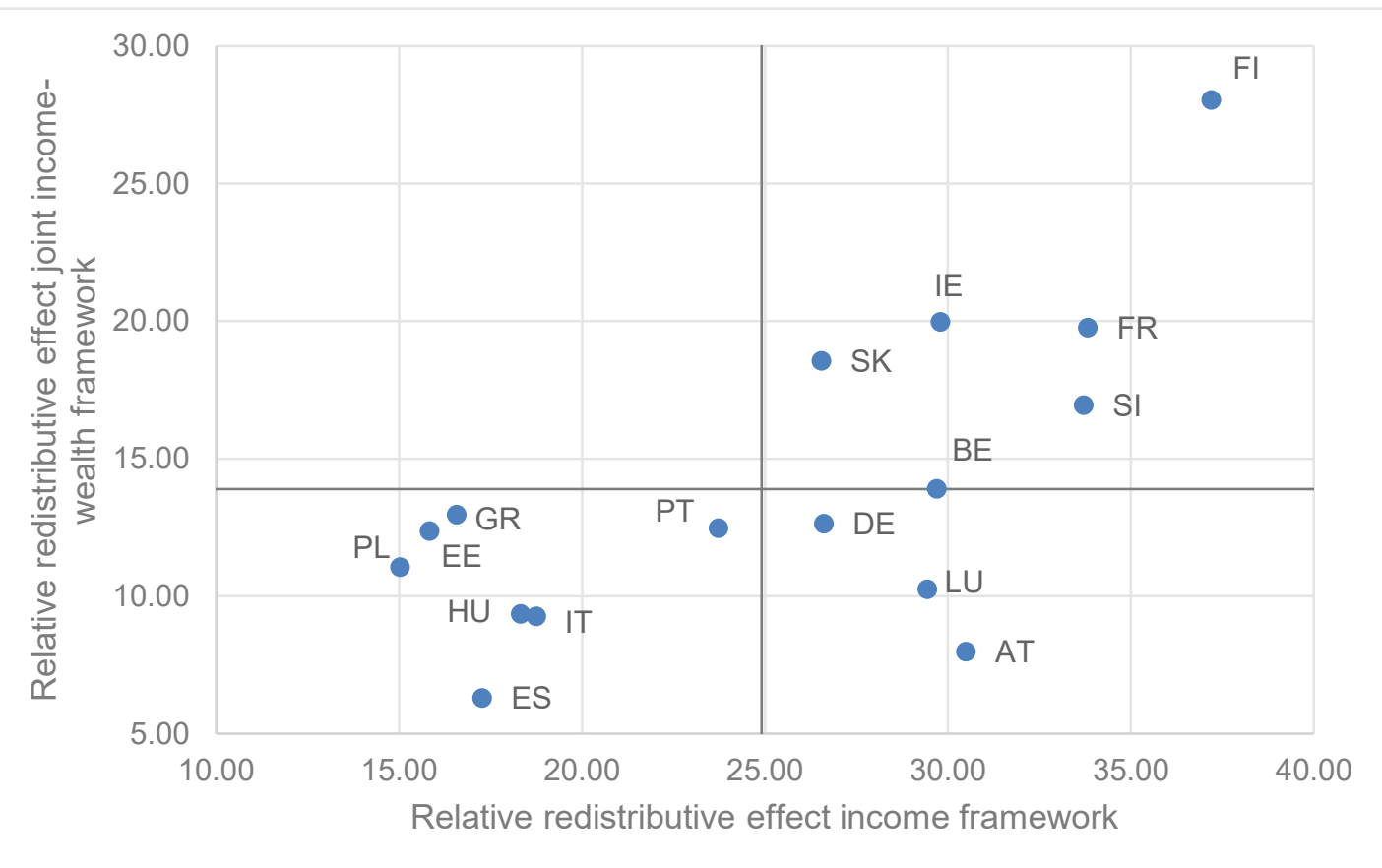

Source: Authors' calculations based on HFCS wave 2 and EUROMOD.

52. In what follows the overall redistributive effect is decomposed according to the approach proposed by Lambert \& Pfähler (1988) to highlight the contribution of each instrument of the tax-benefit system. Specifically, the redistributive effect is first decomposed into a vertical-equity effect (VE) for each instrument and a reranking effect $(R R)$ :

$$
R E=V E-R R .
$$

53. The latter captures the fact that individuals may change positions in the distribution before and after redistribution takes place. The vertical-equity effect measures the change in inequality achieved by each instrument in the absence of reranking. The vertical-equity effect of each tax-benefit instrument can be further decomposed into its size and its distribution (i.e. degree of progressivity):

$$
V E=\frac{1}{(1-g)} \sum_{i=1}^{I} g_{i} \prod_{i}^{K} .
$$

54. Where $g$ refers to the overall net fiscal rate, with $g=t-s$ and $t$ representing the average tax rate and $s$ the average benefit rate. Progressivity is measured by the Kakwani index (Kakwani, 1977), which is calculated as the difference between the concentration coefficient of the redistributive instrument and the pre-tax pre-transfer Gini coefficient. The progressivity of the total tax-benefit system is equal to the weighted sum of the progressivity of each redistributive instrument. The results for the decomposition into the separate components are shown in Figure 9, Figure 10 and Table 6.

55. First, Figure 9 shows the vertical-equity effect of each tax-benefit instrument ${ }^{30}$ and the reranking effect (again Panel A presents the situation when the traditional approach is used of assessing against the income distribution alone and Panel B when assessed against the joint income-wealth distribution).

\footnotetext{
${ }^{30}$ For Estonia, France and Ireland no separate results are shown for the capital income tax because capital income is taxed progressively together with other income in the personal income tax (see Table 1).
} 
56. The main results are as follows:

- Social benefits achieve the highest redistribution in all countries and in both frameworks, which is in line with previous research (Causa \& Hermansen, 2019; Immervoll \& Richardson, 2011).

- Personal income taxes (PIT) have the second highest redistributive effect, except in Hungary where social security contributions are more redistributive (the Hungarian PIT consists of a low level flat tax: see also Figure 10 and Table 6) and the Slovak Republic, where PIT and SIC achieve about the same redistribution.

- Social security contributions (SIC) have a mixed effect across countries and the two assessment frameworks: in the income framework they have a positive redistributive effect in Hungary, the Slovak Republic and Slovenia, a negative redistributive impact in Poland and Germany and no significant impact in all other countries. In the joint income-wealth framework they only have a positive redistributive effect in the Slovak Republic, a negative effect in Austria, Luxembourg, Germany and France and hardly any effect in the other countries.

- Capital income taxes (KIT) and wealth-related taxes have no significant redistributive impact averaged across all countries. Yet, while capital income taxes have a positive effect in all cases, taxes on the stock or transfers of wealth sometimes have a negative redistributive impact (i.e. increasing rather than decreasing inequality), in particular in the income framework. Although KIT are more progressive than PIT (Table 6) they have a low redistributive impact because of their very small size (Figure 10). Wealth-related taxes are also small in size (Figure 10), but importantly in about half the countries studied they are also regressive or proportional (Table 6).

- In general we find the same order of importance of the redistributive instruments in the joint incomewealth framework as in the traditional income only framework.

57. The decrease in the overall redistributive effect (Figure 7 and Figure 8 ) is the result of a decrease in the redistributive impact of all income-based tax-benefit instruments (social benefits, PIT, SIC, KIT). Indeed, the VE of all these instruments is lower in the joint income-wealth framework than in the traditional income framework (exceptions are the VE of SIC in Greece, Spain and most importantly Poland). However, in all countries the decrease in the redistributive effect is stronger for the PIT (on average about half) than social benefits (decreases with a third on average). For social benefits the decrease in redistributive effect is the lowest in Finland and Slovak Republic, for PIT in Greece and Finland. The largest drops in VE, in contrast, are found for Spain and Luxembourg in case of social benefits and Hungary and Belgium for the PIT. In case of SIC and KIT the patterns are somewhat different across countries, but they remain hardly redistributive in the joint income-wealth framework. As expected, the VE of wealth-related taxes becomes or remains positive, although insignificant, when wealth is taken into account in the assessment framework.

58. The reranking effect (i.e. individuals switching positions between the distributions before and after redistribution) is on average equal to 0.015 in the income framework and 0.008 in the joint income-wealth framework. The effect is particularly important in Ireland, France, Finland and Slovenia.

59. Figure 10 shows results for the first subcomponent of the VE, namely the size of the tax-benefit instruments as a percentage of the pre-transfer pre-tax distribution (i.e. market and pension income (plus gross annuitized net wealth)). In both frameworks, we find that the PIT is often the largest instrument, with an average overall tax rate of $10.6 \%$ in the joint income-wealth framework. PIT rates are particularly high in Belgium (18.5\%), Finland (18.2\%) and Ireland (17.2\%). However, in Austria, Hungary, Slovenia and Slovak Republic SIC have the largest size, while benefits are the largest instrument in France and Spain. These patterns are in line with previous research (Causa \& Hermansen, 2019; Verbist \& Figari, 2014). Remember that public pensions are not included in the social benefits variable in the approach used in the 
main text of this paper; social benefits are the largest instrument in all countries except Belgium, Finland and Ireland when public pensions are also considered as transfers. ${ }^{31}$

Figure 9. The absolute redistributive effects of various tax-benefit instruments, overall population 2017

\section{Panel A. Income framework}

- VE of social benefits

- VE of capital income tax

- Total absolute RE

VE of social insurance contributions - Reranking

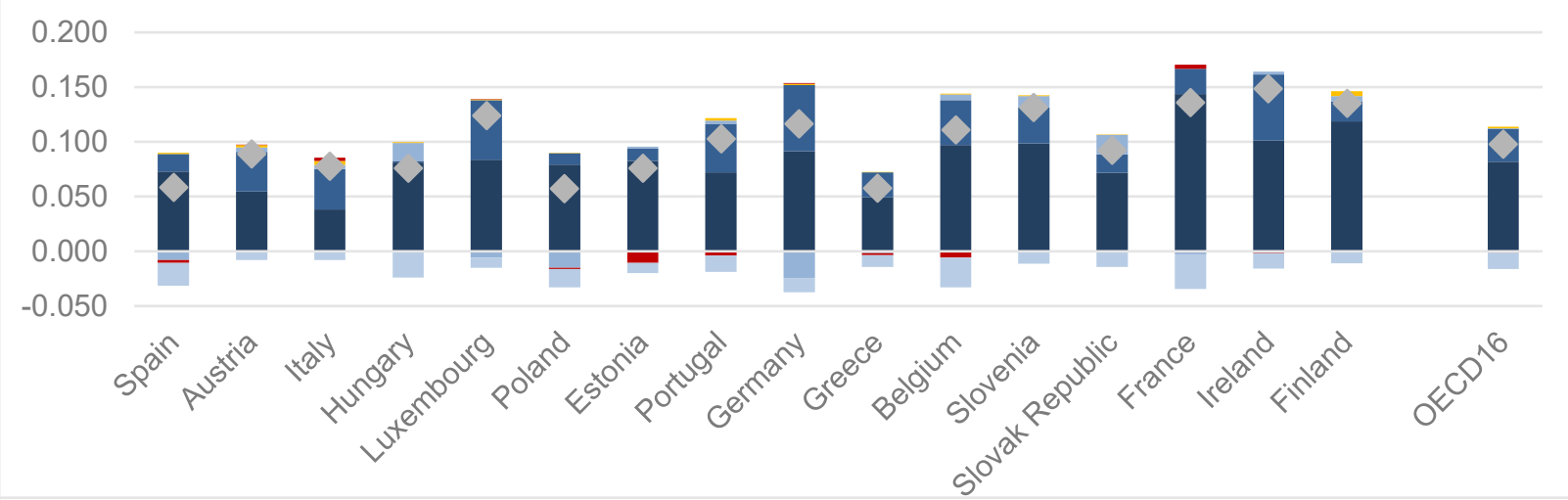

\section{Panel B. Joint income-wealth framework}

- VE of social benefits

- VE of capital income tax

- Total absolute RE
- VE of personal income tax

- VE of wealth-related taxes
VE of social insurance contributions Reranking

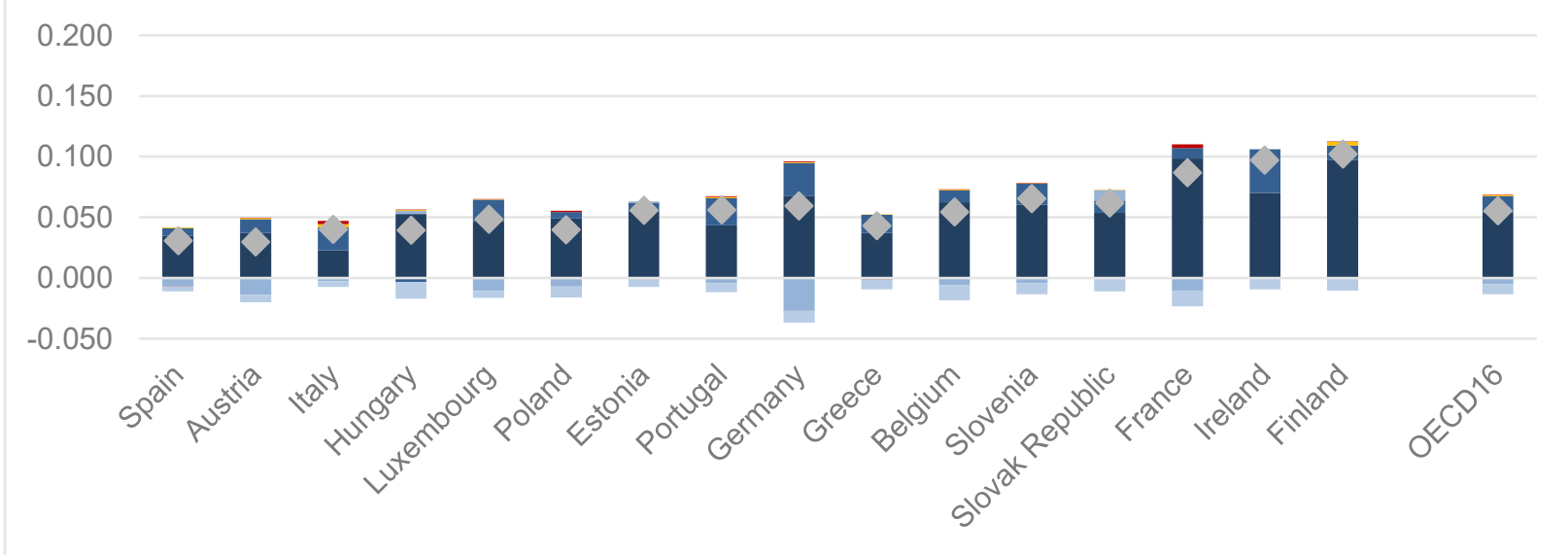

Notes: RE=redistributive effect, VE=vertical equity. The absolute redistributive effect is given by the difference between pre- and post-Gini (see Figure 8). Countries are ranked in ascending order of the relative redistributive effect in the joint income-wealth framework.

Source: Authors' calculations based on HFCS wave 2 and EUROMOD.

31 The figures in Annex B show the overall redistributive effects when pensions are considered as transfers. The decomposition results are not shown, but available from the authors upon request. 
Figure 10. The size of the tax-benefit instruments, overall population - 2017

\section{Panel A. Income framework}

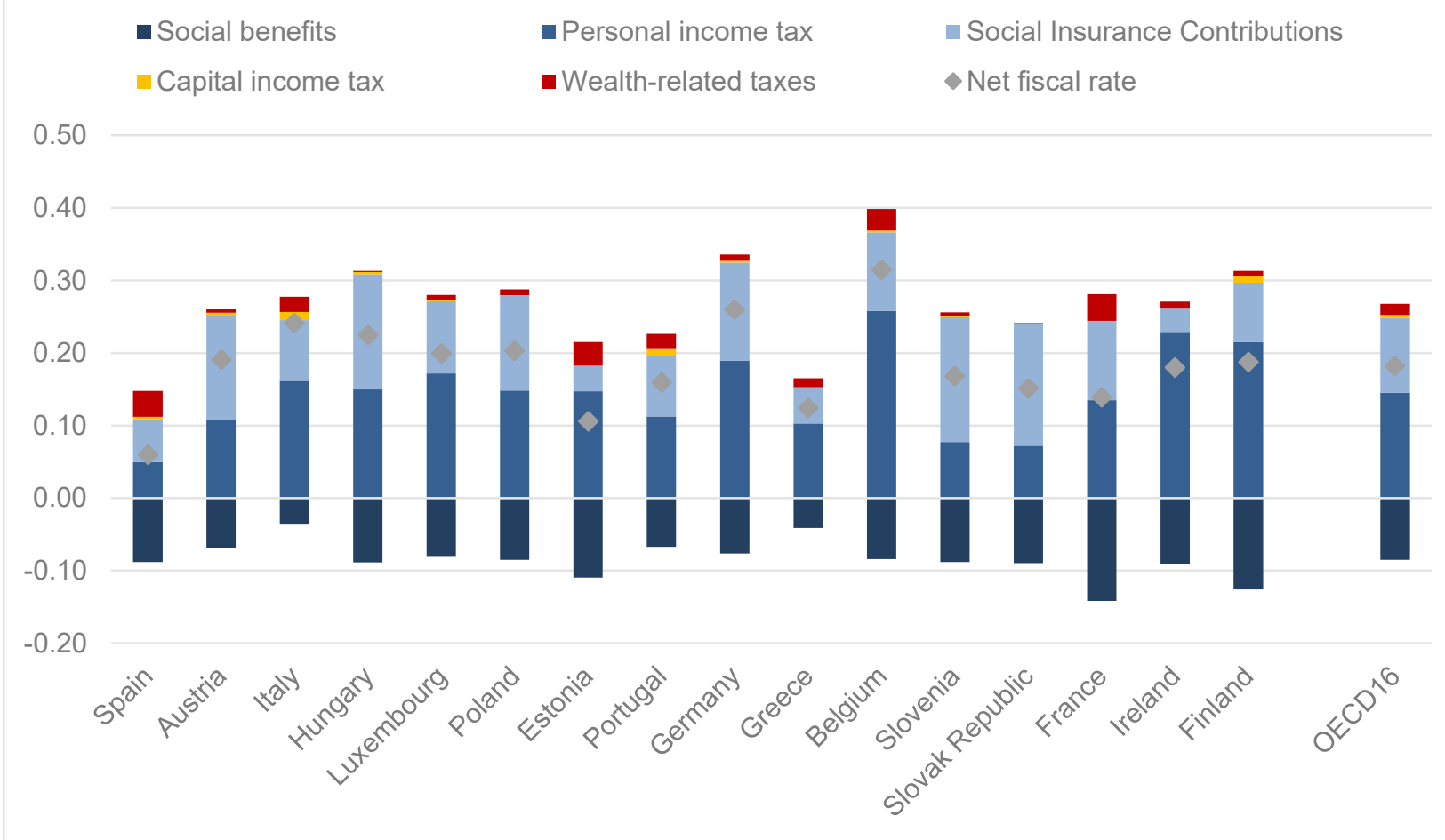

Panel B. Joint income-wealth framework

$\begin{array}{lll}\square \text { Social benefits } & \square \text { Personal income tax } & \square \text { Social Insurance Contributions }\end{array}$

0.40

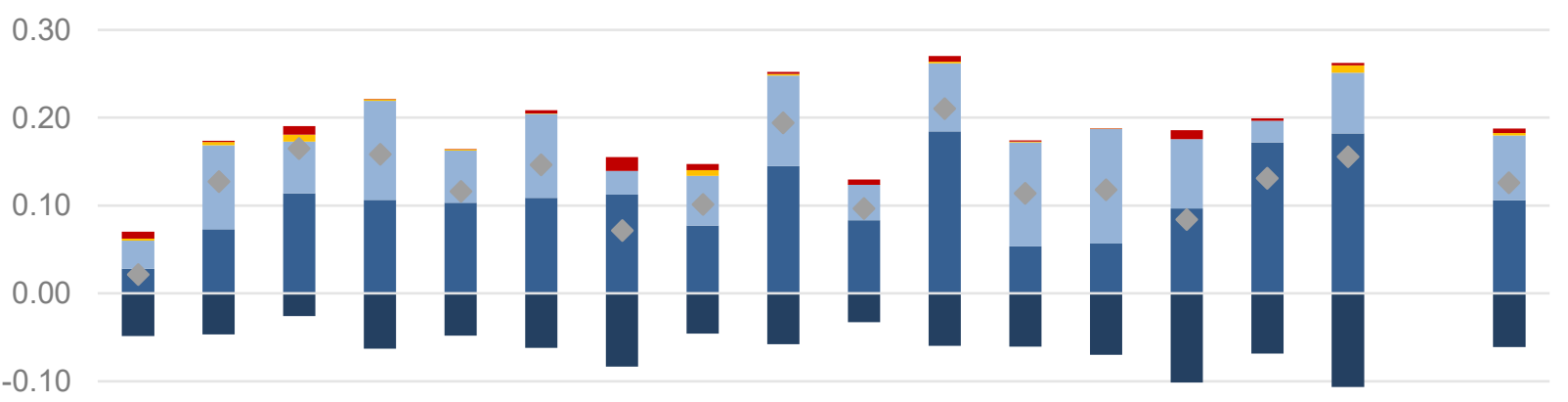

$-0.20$

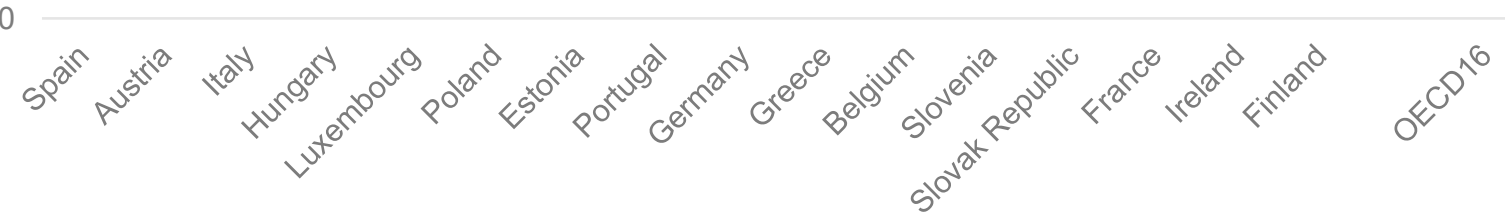

Notes: Countries are ranked in ascending order of the relative redistributive effect in the joint income-wealth framework. Source: Authors' calculations based on HFCS wave 2 and EUROMOD. 
60. In cross-country comparison KIT rates are the highest in Italy, Finland and Portugal, while they are low in the Slovak Republic, Greece and Poland. Wealth-related taxes usually do not play a major role, with an average tax rate of all wealth taxes combined of $0.5 \%$ in the joint income-wealth framework. They are somewhat more important in Italy $(1 \%)$, France $(0.8 \%)$, Spain $(0.8 \%)$, Portugal $(0.7 \%)$ and Belgium $(0,7 \%)$. In the income framework the average wealth tax rate is $1.5 \%$ and largest in France (3.6\%), Spain (3.5\%), Estonia (3.3\%) and Belgium (3\%). As discussed above (Table 2), the relatively higher rates in these countries reflect the effect of the general net wealth taxes in the case of France and Spain, the relatively strong taxation of inheritances and gifts in Belgium and the specific net wealth tax on financial assets in Italy.

61. Comparing the results for the two assessment frameworks in Panel $A$ and $B$, we find that the size of all instruments decreases by the same percentage (except for wealth-related taxes) due to the use of a larger denominator, i.e. including gross annuitized net wealth provides a broader concept of the potential tax base. On average, the size of the tax-benefit instruments is $28 \%$ lower in the joint income-wealth framework than in the traditional income framework. The largest difference is found for Spain (45\%) and the lowest for Finland (15\%). For the wealth-related taxes not only the denominator changes, but also the fact that the nominal value of taxes is taken into account in the income framework, while their effect is included either in the interest rate used for the annuity (recurrent taxes) or the amount that is subject to the annuitisation formula (event wealth taxes) (see Section 4). As a consequence, their relative size drops more, by $68 \%$ on average.

62. Finally, Table 6 presents the results of the second subcomponent determining the VE of tax-benefit instruments, namely their progressivity, measured by the Kakwani index. A positive Kakwani index refers to a progressive or pro-poor instrument, a Kakwani index not significantly different from 0 reflects a proportional instrument (these cases are listed in the table notes) and a negative Kakwani index refers to a regressive instrument. ${ }^{32}$ The table presents the Kakwani index in both frameworks as well as whether the Kakwani index in the joint income-wealth framework is higher $(\uparrow)$, lower $(\downarrow)$ or more or less equal $(-)$ to the Kakwani index in the traditional income framework. The different shades of blue reflect within each instrument in which countries the Kakwani index is relatively high (dark blue), average or low (light blue).

63. In all countries and in both assessment frameworks social benefits are the most progressive instrument, followed by the KIT. Hence, KIT are more progressive than PIT (with the exception of Portugal in both frameworks and Spain in the income framework) which follows from the fact that capital income is more concentrated at the top of the distribution than other types of income. SIC are generally regressive or close to proportional. The same is true for wealth-related taxes when assessed against the distribution of income alone, although slightly progressive in Italy, France, Germany and Spain. In the joint incomewealth framework about half of the countries have progressive wealth-related taxes, while in the other half wealth-related taxes are regressive or proportional.

64. In Kuypers et al. (2020) we analyse the different types of wealth-related taxes separately for six countries and show that the net wealth taxes of Spain and France are the most progressive type of wealthrelated tax. Also capital income taxes and inheritance and gift taxes are strongly progressive, while recurrent and transfer taxes on real estate are rather regressive or close to proportional. Since the latter are the most important wealth-related taxes in most countries, the overall effect of wealth-related taxation is often regressive or proportional.

\footnotetext{
${ }^{32}$ Note that for benefits and the total of taxes and benefits the Kakwani index can be larger than 1, see Lambert and Pfähler (1988).
} 
Table 6. Kakwani indices, overall population - 2017

\begin{tabular}{|c|c|c|c|c|c|c|c|c|c|c|c|c|c|c|c|c|c|c|}
\hline & \multicolumn{3}{|c|}{ Social benefits } & \multicolumn{3}{|c|}{ Personal income tax } & \multicolumn{3}{|c|}{$\begin{array}{l}\text { Social insurance } \\
\text { contributions }\end{array}$} & \multicolumn{3}{|c|}{ Capital income tax } & \multicolumn{3}{|c|}{ Wealth-related taxes } & \multicolumn{3}{|c|}{ Total } \\
\hline & INC & INC-NW & & INC & INC-NW & & INC & INC-NW & & INC & INC-NW & & INC & INC-NW & & INC & INC-NW & \\
\hline Spain & 0.782 & 0.695 & $\downarrow$ & 0.298 & 0.227 & $\downarrow$ & -0.126 & -0.198 & $\downarrow$ & 0.266 & 0.314 & $\uparrow$ & -0.073 & -0.006 & $\uparrow$ & 1.248 & 1.605 & $\uparrow$ \\
\hline Austria & 639 & 601 & $\uparrow$ & 0.271 & 136 & $\downarrow$ & 0.023 & & $\downarrow$ & 0.305 & 0.234 & $\downarrow$ & 0.020 & 0.195 & $\uparrow$ & 0.412 & 0.247 & $\downarrow$ \\
\hline Italy & 0.793 & 0.738 & $\downarrow$ & 0.173 & 0.141 & $\downarrow$ & 0.035 & -0.040 & $\downarrow$ & 0.263 & 0.269 & - & 0.101 & 0.239 & $\uparrow$ & 0.269 & 0.225 & $\downarrow$ \\
\hline Hungary & 0.708 & 0.705 & - & 0.008 & -0.026 & $\downarrow$ & 0.080 & 0.020 & $\downarrow$ & 0.230 & 0.290 & $\uparrow$ & -0.067 & 0.093 & $\uparrow$ & 0.344 & 0.282 & $\downarrow$ \\
\hline Luxembourg & 0.830 & 0.855 & $\uparrow$ & 0.252 & 0.150 & $\downarrow$ & -0.045 & -0.159 & $\downarrow$ & 0.291 & 0.263 & $\downarrow$ & 0.040 & 0.100 & $\uparrow$ & 0.536 & 0.412 & $\downarrow$ \\
\hline Poland & 0.744 & 0.674 & $\downarrow$ & 0.056 & 0.041 & $\downarrow$ & -0.092 & -0.064 & $\downarrow$ & 0.282 & 0.293 & $\uparrow$ & -0.102 & & $\uparrow$ & 0.291 & 0.282 & $\downarrow$ \\
\hline Estonia & 0.673 & 0.612 & $\downarrow$ & 0.070 & 0.059 & $\downarrow$ & 0.043 & 0.033 & $\downarrow$ & n.a. & n.a. & & -0.288 & -0.065 & $\uparrow$ & 0.720 & 0.804 & $\uparrow$ \\
\hline Portugal & 0.906 & 0.853 & $\downarrow$ & 0.330 & 0.259 & $\downarrow$ & 0.029 & -0.070 & $\downarrow$ & 0.197 & 0.155 & $\downarrow$ & -0.159 & 0.108 & $\uparrow$ & 0.620 & 0.559 & $\downarrow$ \\
\hline Germany & 0.892 & 0.933 & $\uparrow$ & 0.236 & 0.154 & $\downarrow$ & -0.134 & -0.210 & $\downarrow$ & 0.290 & 0.285 & - & 0.075 & 0.177 & $\uparrow$ & 0.369 & 0.288 & $\downarrow$ \\
\hline Greece & 1.053 & 1.008 & $\downarrow$ & 0.193 & 0.166 & $\downarrow$ & -0.027 & -0.028 & - & 0.196 & 0.176 & $\downarrow$ & -0.151 & -0.015 & $\uparrow$ & 0.482 & 0.476 & - \\
\hline Belgium & 0.792 & 0.822 & $\uparrow$ & 0.109 & 0.041 & $\downarrow$ & 0.033 & -0.059 & $\downarrow$ & 0.147 & 0.257 & $\uparrow$ & -0.134 & 0.031 & $\uparrow$ & 0.301 & 0.252 & $\downarrow$ \\
\hline Slovenia & 0.931 & 0.880 & $\downarrow$ & 0.350 & 0.290 & $\downarrow$ & 0.051 & -0.031 & $\downarrow$ & 0.369 & 0.416 & $\uparrow$ & -0.078 & 0.134 & $\uparrow$ & 0.703 & 0.580 & $\downarrow$ \\
\hline Slovak Republic & 0.678 & 0.676 & - & 0.197 & 0.157 & $\downarrow$ & 0.091 & 0.058 & $\downarrow$ & 0.328 & 0.335 & - & -0.288 & -0.183 & $\uparrow$ & 0.595 & 0.541 & $\downarrow$ \\
\hline France & 0.872 & 0.886 & $\uparrow$ & 0.147 & 0.082 & $\downarrow$ & -0.021 & -0.122 & $\downarrow$ & n.a. & n.a. & & 0.087 & 0.257 & $\uparrow$ & 1.037 & 1.083 & $\uparrow$ \\
\hline Ireland & 0.913 & 0.890 & $\downarrow$ & 0.217 & 0.180 & $\downarrow$ & 0.065 & 0.025 & $\downarrow$ & n.a. & n.a. & & -0.133 & -0.066 & $\uparrow$ & 0.741 & 0.707 & $\downarrow$ \\
\hline Finland & 0.766 & 0.769 & - & 0.070 & 0.055 & $\downarrow$ & 0.047 & -0.009 & $\downarrow$ & 0.368 & 0.335 & $\downarrow$ & -0.108 & 0.026 & $\uparrow$ & 0.630 & 0.605 & $\downarrow$ \\
\hline OECD16 & 0.811 & 0.793 & $\downarrow$ & 0.186 & 0.132 & $\downarrow$ & 0.003 & -0.061 & $\downarrow$ & 0.272 & 0.279 & - & -0.079 & 0.077 & $\uparrow$ & 0.581 & 0.559 & \\
\hline
\end{tabular}

Notes: INC-NW=joint income-annuitised net wealth framework, INC= income framework. A positive Kakwani index refers to a pro-poor instrument. The third column for each instrument shows whether the Kakwani index in the joint income-wealth framework is higher $(\uparrow)$, lower $(\downarrow)$ or more or less equal $(-)$ to the Kakwani index in the traditional income-wealth framework. The different shades of blue provide an indication within each tax-benefit instrument in which countries the Kakwani index is relatively high (dark blue), average or low (light blue). All Kakwani indices are statistically significant at the $5 \%$ level (i.e. significantly different from proportionality) except for the following: wealth-related taxes Belgium in joint income-wealth framework, wealth-related taxes Germany in income framework, social insurance contributions Greece in both frameworks, wealth-related taxes Greece in joint income-wealth framework, wealth-related taxes Hungary in both frameworks, wealth-related taxes Ireland in income framework, capital income tax and wealth-related taxes Luxembourg in income framework, capital income tax Slovenia in both frameworks, wealth taxes Slovak Republic in income framework and wealth-related taxes Spain in joint income-wealth framework. Countries are ranked in ascending order of the relative redistributive effect in the joint income-wealth framework. Source: Authors' calculations based on HFCS wave 2 and EUROMOD. 
65. Comparing the two assessment frameworks shows that social benefits remain strongly progressive when wealth is taken into account. In some countries progressivity even increases. In other words, social benefits are primarily received by those who have both low income and low wealth, suggesting that asset-testing succeeds in excluding those who can draw on their assets from benefit eligibility (Table 4 and Table 5, see also Marchal et al., (2020 forthcoming)). In contrast, the progressivity of PIT and SIC is lower in the joint income-wealth framework than in the traditional income framework in all countries. SIC are even regressive in 12 out of the 16 countries in the joint income-wealth framework. This is because SIC are levied on those with the highest (labour) incomes, who are not necessarily the ones who are at the top of the distribution when their wealth is taken into account. In most countries, KIT are about as progressive, or more progressive, when wealth is included in the assessment framework. As expected wealth-related taxes are more progressive (or less regressive) when wealth is accounted for in the assessment framework.

66. Total progressivity (i.e. the weighted sum of the progressivity of each instrument) is shown in the last column of Table 6. Progressivity of the total tax-benefit system is in most countries lower in the joint income-wealth framework than in the traditional income framework. Exceptions are Spain, Estonia and France where progressivity increases and Greece with about the same degree of progressivity in the two frameworks.

67. A cross-country comparison within each instrument indicates that:

- social benefits are most progressive in Greece, Germany, Ireland, France and Slovenia, while they are least progressive in Estonia and the Slovak Republic.

- PIT are most progressive in Slovenia, Portugal and Spain. In Austria, Luxembourg and Germany, PIT are relatively progressive in the income framework, but not so in the joint income-wealth framework. In the latter framework PIT are close to proportional in Belgium and Poland and - given its flat rate PIT - also in Hungary in both frameworks.

- SIC are usually close to proportional or even regressive, in the joint income-wealth framework mostly so for Austria and France. The highest Kakwani indices for SIC are found for the Slovak Republic, Ireland, Hungary and Estonia.

- KIT are strongly progressive in Slovenia, Finland and the Slovak Republic, while they are less progressive in Greece and Portugal.

- wealth-related taxes are most progressive in France and Italy, which can be largely attributed to the existence of a general net wealth tax with a high threshold and a specific net wealth tax on financial assets respectively. Interestingly, the Kakwani index of wealth-related taxes in Spain is close to proportional, irrespective of a general net wealth tax being in place (yet a threshold that is almost half of the French one). Wealth-related taxes are most regressive in the Slovak Republic, where only real estate is taxed, which is typically more equally distributed than financial assets.

68. Figure 11 plots the Kakwani index of PIT against that of wealth-related taxes. There is no obvious relationship between the two. On the one hand, Belgium, Finland and Estonia are less progressive than average in both PIT and wealth-related taxes (bottom-left quadrant), while Greece, Spain, Ireland and the Slovak Republic are regressive in their wealth-related taxation, but more progressive than average in their PIT (bottom right). Both PIT and wealth-related taxes are more progressive than average in Italy, Austria, Germany, Luxembourg, Slovenia and Portugal (top right), while France, Poland and Hungary have more progressive wealth-related taxes than average, but less progressive PIT than average (top left). 
Figure 11. Progressivity of personal income and wealth-related taxes in the joint income-wealth framework

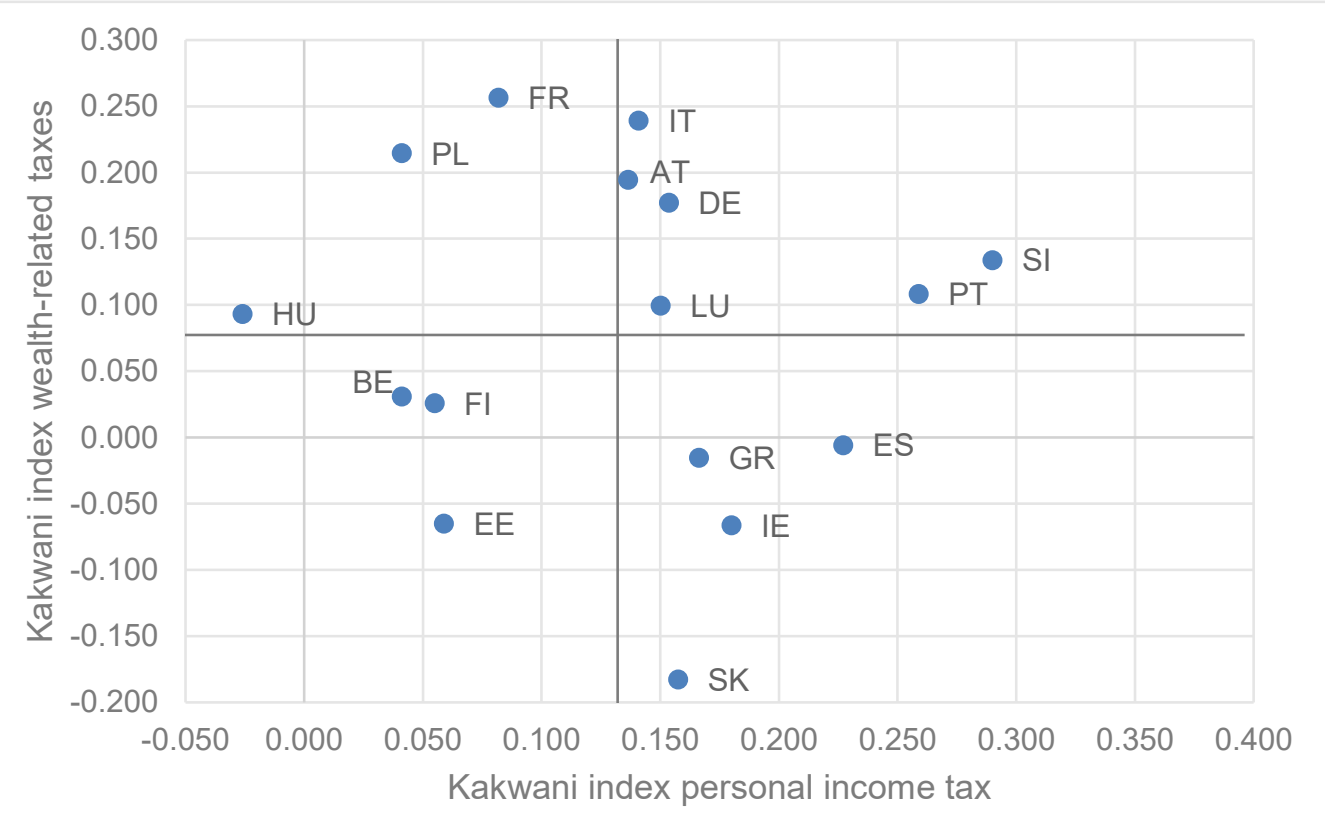

Source: Authors' calculations based on HFCS wave 2 and EUROMOD.

\section{The redistributive effects when considering only liquid assets}

69. An issue often discussed in the wealth literature is which wealth components need to be taken into account, in particular to which extent liquid and non-liquid assets should be treated equally. At the moment, there is no consensus in the literature on whether it is appropriate to include non-liquid assets in the annuity calculation. Indeed, by transforming wealth into an annuity and adding it to income we implicitly assume that wealth is perfectly fungible (Kuypers \& Marx, 2018). This is more likely to be the case for liquid than for non-liquid assets as there are typically costs associated with converting the latter into cash (Kuypers \& Marx, 2019). Moreover, it may not be reasonable to expect households to sell illiquid assets, notably their home, to deal with income or consumption shocks and to pay their taxes. On the other hand, however, those who own real estate are generally better off than those who do not own this type of wealth, and when evaluating redistribution we may want to take this into account (Kuypers \& Marx, 2018).

70. Since it remains an unresolved issue, we contrast the results for total wealth from Section 5 with figures of the absolute and relative redistributive effects in a framework where non-liquid assets (i.e. mainly real estate) and debt related to non-liquid assets (i.e. mortgage debt) are not taken into account. In other words, we only annuitise liquid assets minus non-mortgage debt and add them to income.

71. Both in absolute and relative terms redistributive effects in the joint income-liquid assets framework are very close to the results for the income framework (Table 7). This is due to the fact that liquid assets are more strongly correlated with income than non-liquid assets and that non-liquid assets generally take up a larger share in the total wealth portfolio. Hence, adding only annuitized liquid assets to the framework changes the underlying distribution less than when also non-liquid assets are accounted for.

72. The difference in redistributive effects between the income and joint income-liquid assets frameworks is largest in Spain and Estonia, where it actually goes in the opposite direction than before. Indeed, when only liquid assets are accounted for redistributive effects become larger in these countries than when only income is considered. In most countries redistribution still decreases when liquid assets 
are taken into account, but to a much lesser extent then when all wealth is included. Hence, the overall conclusion that redistribution is weaker when wealth is accounted for does not always hold in the case when only liquid assets are considered.

Table 7. Redistributive effects including vs. excluding non-liquid assets, overall population - 2017

\begin{tabular}{l|c|c|c|c|c|c}
\hline & \multicolumn{3}{|c|}{ Absolute redistributive effect } & \multicolumn{3}{c}{ Relative redistributive effect } \\
\hline & INC & INC-LIQ & INC-NW & INC & INC-LIQ & INC-NW \\
\hline Spain & 0.058 & 0.070 & 0.031 & 13.03 & 15.51 & 6.72 \\
\hline Austria & 0.089 & 0.078 & 0.030 & 30.49 & 26.45 & 7.98 \\
\hline Italy & 0.077 & 0.073 & 0.040 & 18.75 & 17.68 & 9.27 \\
\hline Hungary & 0.076 & 0.071 & 0.039 & 18.32 & 16.94 & 9.35 \\
\hline Luxembourg & 0.124 & 0.109 & 0.048 & 29.44 & 25.15 & 10.26 \\
\hline Poland & 0.057 & 0.059 & 0.039 & 15.02 & 15.54 & 11.06 \\
\hline Estonia & 0.076 & 0.085 & 0.056 & 15.82 & 18.34 & 12.38 \\
\hline Portugal & 0.103 & 0.102 & 0.056 & 23.73 & 23.76 & 12.47 \\
\hline Germany & 0.116 & 0.106 & 0.059 & 26.60 & 24.21 & 12.64 \\
\hline Greece & 0.058 & 0.058 & 0.043 & 16.58 & 16.52 & 12.97 \\
\hline Belgium & 0.111 & 0.102 & 0.055 & 29.69 & 26.13 & 13.91 \\
\hline Slovenia & 0.131 & 0.130 & 0.065 & 33.70 & 33.80 & 16.95 \\
\hline Slovak Republic & 0.092 & 0.090 & 0.062 & 26.54 & 26.20 & 18.56 \\
\hline France & 0.136 & 0.134 & 0.087 & 33.82 & 34.17 & 19.77 \\
\hline Ireland & 0.148 & 0.139 & 0.097 & 29.79 & 27.84 & 19.98 \\
\hline Finland & 0.135 & 0.131 & 0.102 & 37.20 & 36.34 & 28.04 \\
\hline & & & & & & \\
\hline OECD16 & 0.099 & 0.096 & 0.057 & 24.91 & 24.04 & 13.89 \\
\hline
\end{tabular}

Notes: INC-NW= joint income-net wealth framework, INC-LIQ= joint income-liquid assets framework, INC= income framework. The different shades of blue provide an indication within the absolute and relative redistributive effect respectively which is relatively high, average or low. Countries are ranked in ascending order of the relative redistributive effect in the joint income-wealth framework.

Source: Authors' calculations based on HFCS wave 2 and EUROMOD.

\section{The redistributive effects for the elderly and non-elderly population}

73. As argued earlier, our main results may be driven by the reranking of the elderly population. Indeed, reranking between the income distribution and the wealth distribution is more likely among elderly than among the working age population as they more often combine low incomes with median to high wealth holdings. The life-cycle character of wealth accumulation predicts high wealth at retirement. Because the elderly have shorter life expectancies the annuities added to their income are larger even in case working-age people have the same level of wealth. Moreover, since the annuity allows wealth to grow only via the interest rate, it does not reflect paying down debt and the savings and accumulation potential of non-elderly households over their future working lives (Kuypers \& Marx, 2018).

74. Nevertheless, the overall conclusion that redistribution decreases substantially when wealth is included in the assessment framework holds when only the active age population is considered. The total redistributive effects (in line with the previous results starting from market plus pension income) in the income framework (Panel A) and the joint income-wealth framework (Panel B) are presented in Figure 12 for the non-elderly population and in Figure 13 for the elderly population. Comparing Figure 12 with Figure 
7 the results and conclusions remain largely the same: redistribution is considerably lower in the joint income-wealth framework than in the income only framework.

75. Yet, when only considering the non-elderly population redistribution is slightly higher in the joint income-wealth framework than when the total population is taken into account. The redistributive effects of the elderly are, indeed, more strongly affected, as shown in Figure 13. In general for both the elderly and the non-elderly taking into account wealth in the assessment framework results in larger Gini coefficients before and after taxes and transfers and lower absolute and redistributive effects. On average the absolute redistributive effect decreases from 0.103 Gini points $(25.4 \%$ relative redistribution) in the income framework to 0.067 Gini points (16.5\% relative redistribution) in the joint income-wealth framework for the non-elderly and for the elderly these numbers are equal to $0.067(18.8 \%)$ and $0.023(6.3 \%)$ respectively. Hence, on average the redistributive effects of the non-elderly decrease by about one-third between the two frameworks, while it decreases by two-thirds for the elderly. The redistributive effects of the elderly in the joint income-wealth framework even become slightly negative for Belgium and Hungary.

76. Annex $B$ shows the results for the non-elderly and elderly population respectively relative to market income alone (and hence including the impact of pensions in the redistributive effect). As expected, inequality before taxes and transfers is much higher, while redistributive effects are much larger compared to the results when starting from market plus pension income and the effect is especially large for the elderly. Inequality before taxes and transfers among the elderly is considerably lower in the joint incomewealth framework than in the income framework pointing towards the fact that many elderly have zero market incomes resulting in large inequality. At the same time most elderly have median to high wealth holdings and including those has an equalising effect.

77. It is often argued that the liquidity issue discussed in the previous section is even more important for the elderly population. According to the life cycle hypothesis dissaving takes place after retirement to keep living standards at the same level as before retirement. If their wealth is largely stuck in illiquid assets such as real estate such dissaving may become difficult or even undesirable. Therefore, Table 8 shows as in Table 7 absolute and redistributive effects when only liquid assets and related debt are taken into account in the annuitisation, this time only for the elderly population. As before, we find that redistributive effects remain closer to the redistributive effects of the income framework when only liquid assets are taken into account compared to when all wealth is accounted for. The main exception is Belgium where redistributive effects decrease strongly also when only liquid assets are taken into account. Comparing the results to those of Table 7 the differences in redistributive effects between the income and joint incomeliquid assets frameworks are slightly larger for the elderly than for the total population. So, here again we find that including wealth, whether all or only part of it, affects redistribution more strongly among the elderly than among the non-elderly. 
Figure 12. The redistributive effects for non-elderly, relative to market plus pension income - 2017
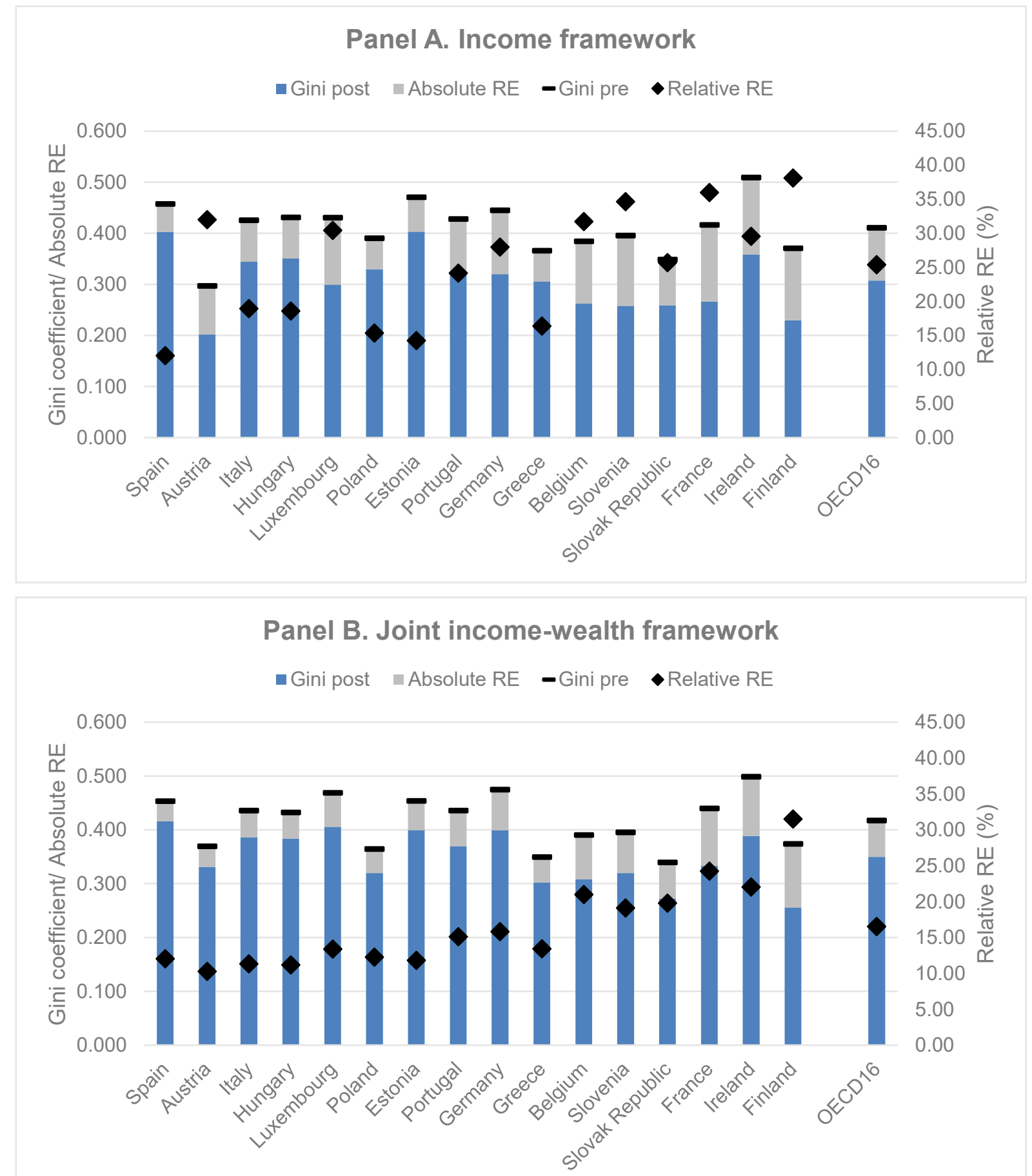

Notes: RE=redistributive effect. Gini post refers to the Gini coefficient after redistribution, which is the Gini of disposable income in the income framework and the Gini of disposable income plus net annuitised net wealth in the joint income-wealth framework. Gini pre refers to the Gini coefficient before redistribution, which is in this figure the Gini of market \& pension income in the income framework and the Gini of market \& pension income plus gross annuitised net wealth in the joint income-wealth framework. Countries are ranked in ascending order of the relative redistributive effect in the joint income-wealth framework for the total population.

Source: Authors' calculations based on HFCS wave 2 and EUROMOD. 
Figure 13. The redistributive effects for elderly, relative to market plus pension income - 2017
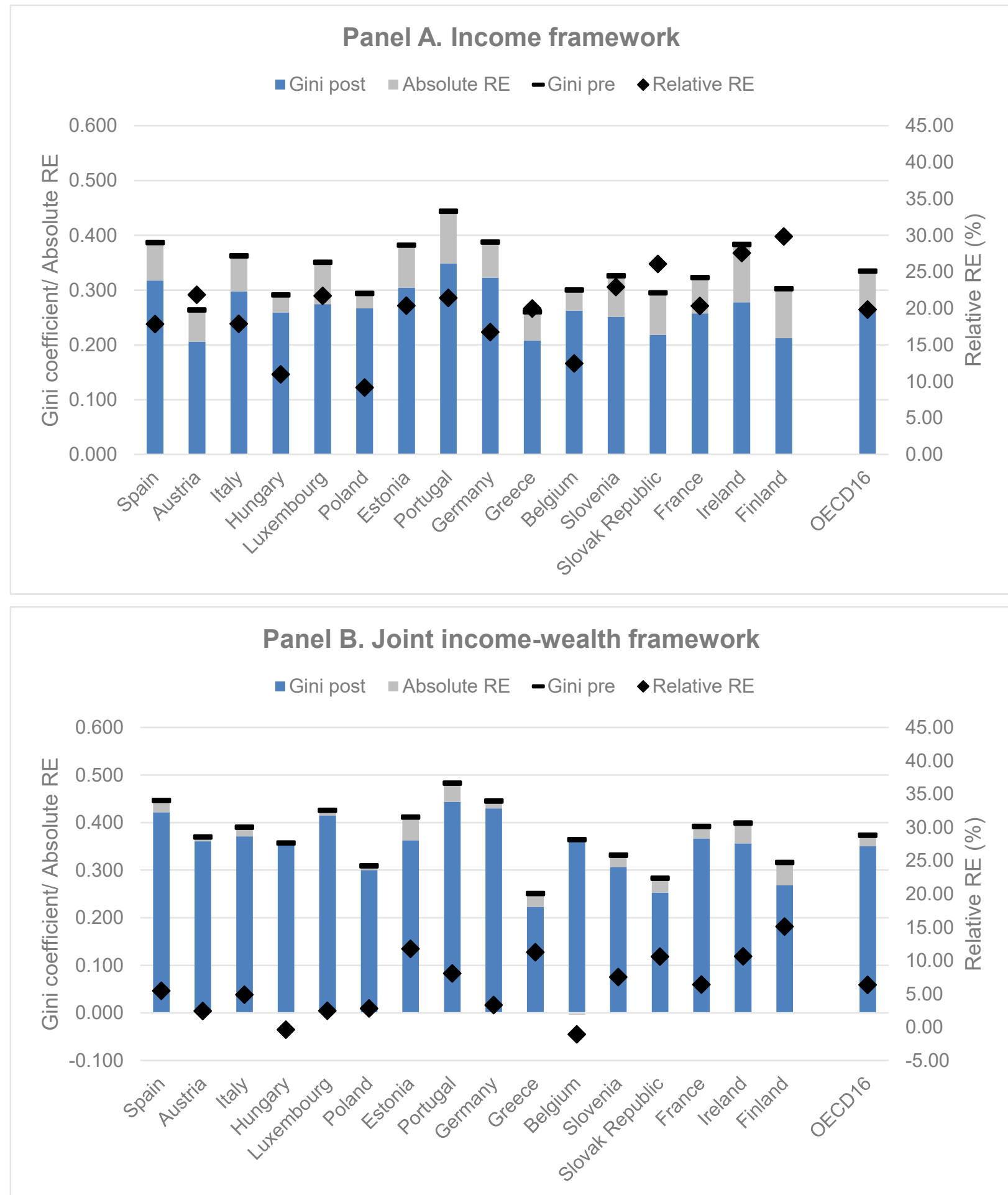

Notes: RE=redistributive effect. Gini post refers to the Gini coefficient after redistribution, which is the Gini of disposable income in the income framework and the Gini of disposable income plus net annuitised net wealth in the joint income-wealth framework. Gini pre refers to the Gini coefficient before redistribution, which is in this figure the Gini of market \& pension income in the income framework and the Gini of market \& pension income plus gross annuitised net wealth in the joint income-wealth framework. Countries are ranked in ascending order of the relative redistributive effect in the joint income-wealth framework for the total population.

Source: Authors' calculations based on HFCS wave 2 and EUROMOD. 
Table 8. Redistributive effects including vs. excluding non-liquid assets, elderly population - 2017

\begin{tabular}{l|c|c|c|c|c|c}
\hline & \multicolumn{3}{|c|}{ Absolute redistributive effect } & \multicolumn{3}{c}{ Relative redistributive effect } \\
\hline & INC & INC-LIQ & INC-NW & INC & INC-LIQ & INC-NW \\
\hline Spain & 0.069 & 0.066 & 0.024 & 17.85 & 15.49 & 5.46 \\
\hline Poland & 0.027 & 0.031 & 0.009 & 9.13 & 10.41 & 2.83 \\
\hline Greece & 0.052 & 0.051 & 0.028 & 19.97 & 19.38 & 11.24 \\
\hline Hungary & 0.032 & 0.025 & -0.001 & 10.98 & 8.30 & -0.38 \\
\hline Italy & 0.065 & 0.057 & 0.019 & 17.88 & 15.58 & 4.87 \\
\hline Estonia & 0.078 & 0.080 & 0.048 & 20.36 & 21.02 & 11.74 \\
\hline Portugal & 0.095 & 0.087 & 0.039 & 21.43 & 20.03 & 8.05 \\
\hline Germany & 0.065 & 0.041 & 0.015 & 16.75 & 10.44 & 3.31 \\
\hline Luxembourg & 0.076 & 0.047 & 0.010 & 21.70 & 12.84 & 2.44 \\
\hline Belgium & 0.037 & 0.006 & -0.004 & 12.47 & 1.65 & -1.07 \\
\hline Slovak Republic & 0.077 & 0.072 & 0.030 & 26.07 & 24.88 & 10.60 \\
\hline Austria & 0.058 & 0.043 & 0.009 & 21.84 & 15.63 & 2.42 \\
\hline Ireland & 0.106 & 0.086 & 0.042 & 27.56 & 21.12 & 10.63 \\
\hline Slovenia & 0.075 & 0.070 & 0.025 & 22.90 & 21.76 & 7.53 \\
\hline France & 0.066 & 0.044 & 0.025 & 20.33 & 14.31 & 6.39 \\
\hline Finland & 0.090 & 0.072 & 0.048 & 29.83 & 22.02 & 15.09 \\
\hline & & & & & & \\
\hline OECD16 & 0.067 & 0.055 & 0.023 & 19.82 & 15.93 & 6.32 \\
\hline
\end{tabular}

Notes: INC-NW= joint income-net wealth framework, INC-LIQ= joint income-liquid assets framework, INC= income framework. The different shades of blue provide an indication within the absolute and relative redistributive effect respectively which is relatively high, average or low. Countries are ranked in ascending order of the relative redistributive effect in the joint income-wealth framework of the total population.

Source: Authors' calculations based on HFCS wave 2 and EUROMOD.

\section{Top- and bottom- sensitive redistributive effects}

78. In this section, we carry out a sensitivity analysis by estimating redistributive effects based on Gini coefficients sensitive to the top and bottom parts of the distribution. This approach provides a picture of how different parts of the distribution are affected by the tax-benefit system when using the two different frameworks. Since the distribution of wealth is more skewed than the distribution of income, the redistributive effect of taxes and benefits might be more affected by the inclusion of wealth when a larger weight is given to their effect at the top or the bottom. For this purpose we calculate redistributive effects based on cases of the Generalized Gini index (also called single-parameter Gini or S-Gini) (Donaldson \& Weymark, 1983; Donaldson \& Weymark, 1980; Yitzhaki, 1983). The S-Gini coefficient is expressed as a weighted average of the difference between the Lorenz curve $(L)$ and the line of perfect equality, taking into account an inequality aversion parameter $(v)$.

$$
G(v)=\int_{0}^{1} v(v-1)(1-s)^{v-2}(s-L(s)) d s, \quad \text { where } v>1 .
$$

79. Standard Gini coefficients and hence the standard redistributive effects shown above are obtained by setting $v$ equal to 2 , while higher values result in indices putting relatively more weight on how redistribution affects individuals at the bottom of the distribution and indices with a $v$ lower than 2 put relatively greater weight on what happens at the top. Previous studies have generally used inequality 


\section{6}

DELSA/ELSA/WD/SEM(2021)4

aversions between 1.5 (i.e. top-sensitive Gini coefficient) and 4 (i.e. bottom-sensitive Gini coefficient) (Immervoll \& Richardson, 2011; Jenkins \& Van Kerm, 2006; Kuypers, Figari, \& Verbist, 2019).

80. Table 9 presents the absolute and relative redistributive effects in the two assessment frameworks based on the standard Gini coefficient used in the analyses above and compares it with redistributive effects based on the bottom-sensitive and top-sensitive S-Gini coefficients. Comparing first within each framework, we find that although absolute redistributive effects are always higher for the bottom-sensitive S-Gini coefficients than for the conventional Gini and the top-sensitive S-Gini, relative redistributive effects are often more or less the same across the different Gini measures (a slightly larger difference in the joint income-wealth framework).

81. A comparison between both assessment frameworks first shows that our main conclusion is robust to the choice of the inequality aversion parameter as for all three cases of the S-Gini indicator we find that tax-benefit systems are less redistributive when assessed against the joint income-wealth framework than when only the distribution of income is taken into consideration. Yet, the decrease in redistributive effects between the two frameworks is lower in all countries when the bottom-sensitive S-Gini is used than when the standard Gini or the top-sensitive S-Gini is used (except in Greece where redistributive effects are the same irrespective of the indicator that is used). This is in line with the results of Table 6 that social benefits remain strongly pro-poor when wealth is taken into account. 
Table 9. Top and bottom sensitive redistributive effects, overall population - 2017

\begin{tabular}{|c|c|c|c|c|c|c|c|c|c|c|c|c|}
\hline & \multicolumn{6}{|c|}{ Absolute redistributive effect } & \multicolumn{6}{|c|}{ Relative redistributive effect } \\
\hline & \multicolumn{3}{|c|}{ Income framework } & \multicolumn{3}{|c|}{ Joint income-wealth framework } & \multicolumn{3}{|c|}{ Income framework } & \multicolumn{3}{|c|}{ Joint income-wealth framework } \\
\hline & $v=2$ & $v=4$ & $v=1.5$ & $v=2$ & $v=4$ & $\mathrm{v}=1.5$ & $v=2$ & $v=4$ & $v=1.5$ & $v=2$ & $v=4$ & $v=1.5$ \\
\hline Spain & 0.058 & 0.080 & 0.040 & 0.031 & 0.050 & 0.020 & 13.03 & 11.82 & 13.13 & 6.72 & 7.42 & 6.23 \\
\hline Austria & 0.089 & 0.148 & 0.058 & 0.030 & 0.067 & 0.015 & 30.49 & 30.76 & 30.68 & 7.98 & 12.00 & 5.69 \\
\hline Italy & 0.077 & 0.102 & 0.055 & 0.040 & 0.058 & 0.027 & 18.75 & 15.98 & 19.90 & 9.27 & 8.85 & 9.30 \\
\hline Hungary & 0.076 & 0.119 & 0.052 & 0.039 & 0.071 & 0.025 & 18.32 & 18.80 & 18.25 & 9.35 & 11.37 & 8.48 \\
\hline Poland & 0.057 & 0.088 & 0.038 & 0.039 & 0.071 & 0.025 & 15.02 & 14.86 & 15.08 & 11.06 & 12.80 & 10.28 \\
\hline Estonia & 0.076 & 0.123 & 0.049 & 0.056 & 0.093 & 0.035 & 15.82 & 17.02 & 14.99 & 12.38 & 13.77 & 11.43 \\
\hline Portugal & 0.103 & 0.143 & 0.073 & 0.056 & 0.091 & 0.037 & 23.73 & 22.00 & 24.54 & 12.47 & 13.69 & 11.74 \\
\hline Germany & 0.116 & 0.181 & 0.079 & 0.059 & 0.114 & 0.035 & 26.60 & 27.45 & 26.24 & 12.64 & 16.56 & 10.77 \\
\hline Greece & 0.058 & 0.098 & 0.038 & 0.043 & 0.073 & 0.028 & 16.58 & 17.14 & 16.57 & 12.97 & 13.32 & 12.97 \\
\hline Belgium & 0.111 & 0.181 & 0.071 & 0.055 & 0.117 & 0.029 & 29.69 & 29.22 & 29.28 & 13.91 & 18.65 & 10.98 \\
\hline Slovenia & 0.131 & 0.217 & 0.088 & 0.065 & 0.122 & 0.040 & 33.70 & 35.44 & 33.56 & 16.95 & 20.83 & 15.09 \\
\hline France & 0.136 & 0.213 & 0.092 & 0.087 & 0.158 & 0.054 & 33.82 & 33.12 & 34.26 & 19.77 & 23.69 & 17.87 \\
\hline Ireland & 0.148 & 0.196 & 0.107 & 0.097 & 0.147 & 0.066 & 29.79 & 26.00 & 31.60 & 19.98 & 19.98 & 19.79 \\
\hline Finland & 0.135 & 0.230 & 0.086 & 0.102 & 0.183 & 0.064 & 37.20 & 38.99 & 36.19 & 28.04 & 30.94 & 26.58 \\
\hline OECD16 & 0.099 & 0.154 & 0.067 & 0.057 & 0.101 & 0.035 & 24.91 & 24.73 & 25.01 & 13.89 & 16.04 & 12.74 \\
\hline
\end{tabular}

Notes: v=2 represents the standard Gini, v=4 represents the bottom-sensitive S-Gini measure, v=1.5 represents the top-sensitive S-Gini measure. The different shades of blue provide an indication within each framework where the redistributive effect is relatively high, average or low. Countries are ranked in ascending order of the relative redistributive effect in the joint income-wealth framework.

Source: Authors' calculations based on HFCS wave 2 and EUROMOD. 


\section{Conclusion}

82. The analysis in this paper shows that tax and benefit systems in European welfare states are less redistributive when evaluated against the joint income-wealth framework than if considered under a partial income perspective only. In the majority of the 16 countries considered here both the absolute and the relative redistributive effects in the joint income-wealth framework are about half of those in the traditional income framework. With only a few exceptions, the ranking of countries in terms of relative redistributive effects in the two frameworks, however, remains unchanged.

83. This lower redistributive effect is apparent for all individual tax-benefit instruments we consider, notably social benefits, social insurance contributions, personal income taxes, capital income taxes and wealth-related taxes (apart from very few exceptions). However, the drop is much stronger for taxes than for social benefits, because social benefits are primarily received by households with both low income and low wealth.

84. The drop in redistributive effect follows from the fact that the size of the redistributive instruments is smaller when using the joint income-wealth framework on the one hand, and from a lower degree of progressivity on the other. As taxes and benefits are largely income-related, their size is relatively smaller when measured against a living standards concept that is broadened with wealth. Existing wealth-related taxes are also relatively small, and thus do not have a large redistributive impact. This suggests that taxbenefit systems are largely focused on reducing income inequalities, while considerations about household wealth are often absent when designing redistributive instruments.

85. Also progressivity turns out to be lower when moving from an income to a joint income-wealth framework. In particular, personal income taxes and social insurance contributions are not as progressive when household wealth is being considered because they are levied on households with the highest labour incomes, but these households are not necessarily those with the highest wealth. Social benefits remain the most progressive instrument and in some cases progressivity even increases when wealth in taken into account. Capital income taxes are more progressive than personal income taxes because capital income is more concentrated at the top of the distribution. Nevertheless, their redistributive effect is smaller than for PIT because of the limited revenues currently raised through capital income taxes. All wealthrelated taxes combined are only progressive in the joint income-wealth framework in half of the countries studied. In Kuypers et al. (2020) we show that this is mainly the case because most countries rely heavily on real estate taxation which is often regressive or close to proportional. Net wealth taxes and inheritance and gift taxes, in contrast, are strongly progressive.

86. Due to data constraints capital gains taxes and corporate taxes are not included in our analysis. Since capital gains and corporations are often held by the wealthiest (Cooper, et al., 2016; Roine \& Waldenström, 2012) these are likely to be important taxes in terms of redistribution at the top. However, these taxes currently often do not represent a very large share of total tax revenues. Hence, at present their impact on redistribution is expected to be limited.

87. Even though the redistributive effects of the elderly are more strongly affected by the inclusion of wealth, our overall conclusion remains robust when only the active age population is considered. Reranking among the elderly is more common as they often combine low incomes with median to high wealth holdings. Moreover, the life expectancy dimension of the annuitisation approach assigns higher annuities to the elderly even if active age households own the same amount of wealth. Yet, also among the active age population the share of households combining low income with high wealth and vice versa is non-negligible, resulting in substantial reranking and hence lower redistribution when wealth is taken into account.

88. Redistributive effects are closer to the traditional income framework when only liquid assets are annuitised. This is due to the fact that liquid assets are more strongly correlated with income than non- 
liquid assets and that non-liquid assets generally take up a larger share in the total wealth portfolio. Hence, adding only annuitized liquid assets to the framework changes the underlying distribution less than when also non-liquid assets are accounted for. In some countries the direction of the result even changes, as redistribution increases when liquid assets are taken into account. Again we find that including wealth, whether all or only part of it, affects redistribution more strongly among the elderly than among the nonelderly. These findings need to be taken into consideration when interpreting the main results for total wealth.

89. Our results have several potential policy implications. First, the redistributive effect of tax systems could be strengthened by increasing the share of taxes on capital income and gains. Our results showed that capital income taxes are highly progressive, but that their redistributive impact is limited because of the relatively small levels of revenue that they currently raise. Therefore, more redistribution could be achieved by broadening the capital tax base and by reducing the gap that exists between tax rates on capital income and gains and other forms of income (e.g. labour incomes), and taxing at progressive rates.

90. Moreover, reducing the gap in the tax rates applicable to labour and other income on the one hand and capital income and gains on the other, could further increase redistribution. High labour incomes are concentrated at the top of the income distribution, but less so in the joint income-wealth distribution such that PIT redistribute less. Higher and more progressive tax rates on personal capital income and gains could increase redistribution, could reduce some of the income-shifting incentive among the wealthiest and could potentially provide room to lower the tax burden on workers with lower labour incomes.

91. Second, wealth-related taxes currently only raise limited revenues and taken together they are progressive only in half of the countries studied. This is mainly related to the focus on the taxation of real estate. Inheritance and gift taxes are generally progressive, but have the potential to be even more so if the tax base was broadened. In the same way, by broadening the base of net wealth taxes to include a more comprehensive set of asset types, more revenues and greater redistribution could potentially be achieved, while at the same time improving the neutrality of the taxation of different asset types, which would also improve horizontal equity.

92. Nevertheless, the integrated assessment of people's taxable capacity, taking into account direct taxes on income and wealth, should tackle challenging issues such as those faced by income-poor-assetrich households (Hills, 2013), who often face liquidity problems to finance their needs and pay taxes. When the tax-benefit system only accounts for income, these households tend to receive benefits and pay low taxes. Some financial instruments, facilitated by regulation and tax-rules, might help, as the growing experience of reverse mortgages in many countries demonstrates. Reverse mortgages enable households to access the home equity they have built up during their life and defer the payment of the loan until they sell or move out of the house. This allows them to have additional resources to face their needs without demanding public assistance.

93. An important caveat of more wealth-related taxation, however, applies with respect to the elderly: given that wealth holdings are important as a way of saving for old age, policies should be carefully designed when it comes to considering wealth as a taxable base or as part of the means-test to deliver social protection benefits. Since part of the wealth holdings of the elderly may be needed for e.g. additional long-term care needs, it is important to allow for tax exemptions so as not to place an undue burden on vulnerable elderly households.

94. In addition, fighting tax evasion and closing loopholes is key. Major steps have already been taken to enhance exchange of information and international cooperation, for instance by the OECD through its OECD/G20 Standard for Automatic Exchange of Financial Account Information in Tax Matters (OECD, 2018). This standard has been widely adopted but there remains scope for strengthening efforts from an equity perspective. The developments in the automatic exchange of information will provide governments with the improved capabilities to strengthen the taxation of capital income and gains, which could lead to higher revenues and potentially more redistribution from these taxes. 
95. Finally, at the benefit side we find that they remain strongly pro-poor when including wealth in the analytical framework. This suggests that asset-testing works to target the needy. Asset testing, however, also has some drawbacks (such as discouraging savings), which might call for developing new types of policies that focus on helping vulnerable households to build up wealth holdings. Encouraging asset accumulation among the poor can be seen as a potential new social policy strategy complementing existing ones. These so-called 'asset-based social policies' provide incentives to households to build up savings and assets. The policies that currently exist in most European countries typically encourage asset accumulation through tax incentives, which often make them unavailable for the poor (Kuypers S. , 2018) and are thus regressive. Hence, redistribution might also be increased by reforming tax expenditures or abolish some of them. In several countries tax expenditures for mortgage interests have already been abolished over the last few years. 


\section{References}

Alstadsæter, A., Johannesen, N., \& Zucman, G. (2019). Tax evasion and inequality. American Economic Review, 109(6), 2073-2103.

Arnold, J. M., Brys, B., Heady, C., Johansson, A., Schwellnus, C., \& Vartia, L. (2011). Tax Policy for Economic Recovery and Growth. Economic Journal, 121, F59-F80.

Bach, S., Beznoska, M., \& Steiner, V. (2014). A wealth tax on the rich to bring down public debt? Revenue and distribution effects of a capital levy in Germany. Fiscal Studies, 35(1), 67-89.

Bach, S., Thiemann, A., \& Zucco, A. (2019). Looking for the missing rich: Tracing the top tail of the wealth distribution. International Tax and Public FInance, 26(6), 1234-1258.

Balestra, C., \& Tonkin, R. (2018). Inequalities in household wealth across OECD countries: Evidence from the OECD Wealth Distribution Database. In OECD Statistics Working Papers (Vol.

2018/01). OECD Publishing, Paris. doi:https://dx.doi.org/10.1787/7e1bf673-en

Bergh, A. (2005). On the counterfactual problem of welfare state research: How can we measure redistribution? European Sociological Review, 21(4), 345-357.

Boone, J., Derboven, J., Figari, F., Kuypers, S., \& Verbist, G. (2019). EWIGE 2 - Update and extension of the EUROMOD wealth taxation project. JRC Working papers on Taxation and Structural Reforms No. 2019/07.

Bradley, D., Huber, E., Moller, S., Nielsen, F., \& Stephens, J. (2003). Distribution and redistribution in postindustrial democracies. World Politics, 55(2), 193-228.

Brandolini, A., Magri, S., \& Smeeding, T. (2010). Asset-based measurement of poverty. Journal of Policy Analysis and Management, 29(2), 267-284.

Causa, O., \& Hermansen, M. (2019). Income redistribution through taxes and tranfers across OECD countries. OECD Economics Department Working Papers No. 1453; Paris: OECD Publishing.

Cooper, M., McClelland, J., Pearce, J., Prisinzano, R., Sullivan, J., Yagan, D., . . Zwick, E. (2016). Business in the United Staes: Who owns it, and how much tax do they pay? Tax Policy and the Economy, 30(1), 91-128.

Decoster, A., \& Van Camp, G. (2001). Redistributive effects of the shift from personal income taxes to indirect taxes: Belgium 1988-93. Fiscal Studies, 22(1), 79-106.

Donaldson, D., \& Weymark, J. (1980). A single-parameter generalization of the Gini indices of inequality. Journal of Economic Theory, 22(1), 67-86.

Donaldson, D., \& Weymark, J. (1983). Ethically flexible gini indices for income distributions in the continuum. Journal of Economic Theory, 29(2), 353-358.

Eurosystem Household Finance and Consumption Network (HFCN). (2016). Statistical tables HFCS wave 2. ECB.

Eurosystem Household Finance and Consumption Network (HFCN). (2016). The Household Finance and Consumption Survey: methodological report for the second wave. ECB Statistics Paper No.17.

Fagereng, A., Guiso, L., Malacrino, D., \& Pistaferri, L. (2020). Heterogeneity and persistence in returns to wealth. Econometrica, 88(1), 115-170.

Harding, M., \& Marten, M. (2018). Statutory tax rates on dividends, interest and capital gains: The debt equity bias at the personal level. Paris: OECD Publishing.

Hills, J. (2013). Safeguarding social equity during fiscal consolidation: which tax bases to use? The role of tax policy in times of fiscal consolidation (pp. 80-91). European Economy, Economic Papers 502. 
Immervoll, H., \& Richardson, L. (2011). Redistribution policy and inequality reduction in OECD countries: What has changed in two decades? OECD Social, Employment and Migration Working Papers No.122. Paris: OECD.

Jäntti, M., Sierminska, E., \& Smeeding, T. (2008). The joint distribution of household income and wealth. Evidence from the Luxembourg Wealth Study. OECD Social, Employment and Migration Working Papers No.65. Paris: OECD Publishing.

Jenkins, S., \& Van Kerm, P. (2006). Trends in income inequality, pro-poor income growth, and income mobility. Oxford Economic Papers, 58(3), 531-548.

Jesuit, D. K., \& Mahler, V. A. (2010). Comparing government redistribution across countries: The problem of second-order effects. Social Science Quarterly, 91(5), 1390-1404.

Johns, A., \& Slemrod, J. (2010). The distribution of income tax noncompliance. National Tax Journal, 63(3), 397-418.

Kakwani, N. (1977). Measurement of tax progressivity: an international comparison. Economic Journal, $87,71-80$.

Kavonius, I. K., \& Honkkila, J. (2013). Reconciling micro and macro data on household wealth: a test based on three euro area countries. Journal of Economic and Social Policy, 15(2), Article 3.

Kuypers, S. (2018). Two sides of the same coin? An investigation into the joint distribution of income and wealth and its applications to the analysis of poverty, inequality and redistribution. Doctoraatsthesis, Universiteit Antwerpen. Volledige tekst beschikbaar via: https://hdl.handle.net/10067/1556110151162165141.

Kuypers, S., \& Marx, I. (2018). Estimation of joint income-wealth poverty: A sensitivity analysis. Social Indicators Research, 136(1), 117-137.

Kuypers, S., \& Marx, I. (2019). The truly vulnerable: integrating wealth into the measurement of poverty and social policy effectiveness. Social Indicators Research, 142(1), 131-147.

Kuypers, S., Figari, F., \& Verbist, G. (2019). Redistribution in a joint income-wealth perspective. A crosscountry analysis. Socio-Economic Review.

Kuypers, S., Figari, F., \& Verbist, G. (2020). An assessment of wealth taxes in a joint income-wealth perspective. Herman Deleeck Centre for Social Policy, University of Antwerp: CSB Working Paper No. 20/06.

Lambert, P., \& Pfähler, W. (1988). On aggregate measures of the net redistributive impact of taxation and government expenditure. Public Finance Quarterly, 16(2), 178-202.

Marchal, S., Kuypers, S., Marx, I., \& Verbist, G. (2020 forthcoming). But what about that nice house you own? The impact of asset tests in minimum income schemes in Europe: an empirical exploration. Journal of European Social Policy.

OECD. (2010). Tax expenditures in OECD Countries. Paris: OECD Publishing.

OECD. (2013). OECD Framework for Statistics on the Distribution of Household Income, Consumption and Wealth. Paris: OECD Publishing.

OECD. (2017). Terms of reference. OECD project on the distribution of household incomes. Paris: OECD Publishing.

OECD. (2018). OECD/G20 Inclusive Framework on BEPS Progress report.

OECD. (2018). Taxation of household savings. OECD Tax Policy Studies No.25. Paris: OECD Publishing.

OECD. (2020). Inequalities in household wealth - drivers and policy implications. Paris: OECD Publishing.

Piketty, T. (2014). Capital in the Twenty-First Century. Harvard, USA: Harvard University Press.

Piketty, T., \& Saez, E. (2007). How progressive is the U.S. federal tax system? A historical and 
international perspective. Journal of Economic Perspectives, 21(1), 1-24.

Roine, J., \& Waldenström, D. (2012). On the role of capital gains in Swedish income inequality. Review of Income and Wealth, 58(3), 569-587.

Salverda, W. (2015). EU Policy Making and Growing Inequalities. Discussion Paper 008, European Commission.

Skopek, N., Buchholz, S., \& Blossfeld, H.-P. (2014). National patterns of income and wealth inequality. International Journal of Comparative Sociology, 55(6), 463-488.

Stiglitz, J. E., Sen, A., \& Fitoussi, J.-P. (2009). Report by the Commission on the Measurement of Economic Performance and Social Progress.

Sutherland, H., \& Figari, F. (2013). EUROMOD: the European Union tax-benefit microsimulation model. International Journal of Microsimulation, 6(1), 4-26.

Verbist, G., \& Figari, F. (2014). The redistributive effect and progressivity of taxes revisited: An international comparison across the European Union. Finanz Archiv/Public Finance Analysis, 70(3), 405-429.

Verbist, G., Förster, M., \& Vaalavuo, M. (2012). The impact of publicly provided services on the distribution of resources: Review of new results and methods. OECD Social, Employment and Migration Working Papers No.130, Paris: OECD Publishing.

Vermeulen, P. (2018). How fat is the top tail of the wealth distribution? Review of Income and Wealth, 64(2), 357-387.

Waltl, S. (2020). Multidimensional wealth inequality: A hybrid approach towards distributional national accounts in Europe. INEQ Working Paper Series No. 16, WU Vienna University of Economics and Business.

Weisbrod, B. A., \& Hansen, W. L. (1968). An income-net worth approach to measuring economic welfare. American Economic Review, 58(5), 1315-1329.

Yitzhaki, S. (1983). On an extension of the Gini inequality index. International Economic Review, 24(3), 617-628. 


\section{Annex A: Details on the HFCS-EUROMOD implementation}

96. In this Annex we provide some details on caveats in the HFCS-EUROMOD implementation that should be borne in mind when interpreting the results of this study. First, we list several issues in terms of the simulation of the standard EUROMOD policies based on the HFCS input dataset. With standard EUROMOD policies we refer to all policies which are part of the original scope of the model (e.g. income taxes, social contributions, family benefits, housing benefits, social assistance and other income-related benefits). Overall, the majority of policies can be simulated, but there are some exceptions. Sometimes small adaptations are made to run certain policies. For Spain, for instance, the contributory old-age pension complement ('poacm_s') and the non-contributory old-age pension ('poanc_s') are simulated standardly only for those who are eligible in the input data (i.e. a positive amount of this benefit is observed in the input data). As we do not observe this eligibility in the HFCS data we use an alternative eligibility simulation provided in the model. Even after the adaptations there are, however, certain policies which remain not simulated (see Table A.1.). There may be different reasons why a variable cannot be simulated; some output variables cannot be simulated due to insufficient information in the underlying dataset (column 1), others because there are no eligible cases in the input dataset (column 2) and there are also policies which are already not simulated in the standard version of EUROMOD (i.e. there simulation is 'switched off') (column 3). The variables listed in the first column will likely have the largest effect on the simulation results. See Boone et al. (2019) for further details on the separate variables.

97. Also with regard to the wealth-related policies which are added to EUROMOD based on HFCS not all aspects can be taken into account. First, some policies cannot be simulated due to missing information in the HFCS data. This is the case, for instance, for the Finnish real-estate transfer tax as well as the inheritance and gift tax, the Hungarian recurrent real-property tax and the real-property transfer provision of the Slovak Republic. Second, due to data limitations, capital gains taxes and taxes on financial transactions are not simulated for all countries. Finally, we only cover taxes directly levied on individuals or households, such that corporate income and corporate wealth taxes are also not included in the simulations.

98. Furthermore, as the overview in Table 2 shows in most countries a concept of taxable or cadastral value is used as tax base for the recurrent real estate tax (also for the Italian real-estate transfer tax). Since this information is not observed in the HFCS, we approximate it by applying the ratio between total market value at the country level calculated from the HFCS and total cadastral value at the country level taken from aggregate administrative sources. Moreover, Table 2 also indicated that the recurrent real-estate tax (and in some countries also other taxes) include regional differences, for instance tax rates which can be determined at the regional and/or municipal level. As the HFCS does not include regional information, we mostly relied on average tax rates. Since there exist substantial regional differences in tax rules in Germany and Belgium we do simulate these by randomly assigning HFCS households to the different regions in line with their respective population shares. ${ }^{33}$ In case of the Spanish inheritance and gift tax and the net wealth tax the federal legislation is applied. Finally, inheritances and gifts are surveyed at the household level in the HFCS such that transfers between people living in the same household are not recorded. However, since these inheritances and gifts are often exempt or taxed at a low rate it may have a limited impact on our results. More details on how the HFCS data were adapted to be included in EUROMOD and how the new policies were implemented can be found in Boone et al. (2019).

\footnotetext{
${ }^{33}$ For Belgium and Germany the differences in policy rules between the Flemish, Walloon and Brussels Capital Region and East and West Germany respectively are taken into account. As for the other countries the actual rates within each region are determined at the municipal level for which averages are taken.
} 
Table A. 1. Overview of non-simulated standard EUROMOD output variables

\begin{tabular}{|c|c|c|c|}
\hline Country & $\begin{array}{l}\text { Policies which cannot be simulated specifically } \\
\text { with HFCS data }\end{array}$ & $\begin{array}{l}\text { Policies for which there are no eligible cases in } \\
\text { HFCS }\end{array}$ & $\begin{array}{l}\text { Simulation already switched off in standard } \\
\text { version of EUROMOD }\end{array}$ \\
\hline Austria & $\begin{array}{ll}\text { - } & \text { 'bunct_s': Unemployment benefit (taken } \\
& \text { directly from input data) } \\
\text { - } & \text { 'bunnc_s': Unemployment assistance } \\
\text { - } & \text { 'bunmt_s': Family supplement in } \\
& \text { unemployment assistance }\end{array}$ & $\begin{array}{l}\text { - } \quad \text { 'bcctu_s': Supplement for child care benefit } \\
\text { - } \quad \text { 'pcstu_s': Minimum pension top-up for civil } \\
\text { servants }\end{array}$ & $\begin{array}{ll}\text { - } & \text { 'pch00_s': Child bonus for pensioners } \\
& \text { (included in poa00) } \\
\text { - } & \text { 'pchcs_s': Child bonus for civil servant } \\
& \text { pensioners (included in poacs) }\end{array}$ \\
\hline Belgium & & - ' 'bchba_s': Birth grant & $\begin{array}{l}\text { - } \quad \text { 'bsaoa_s': Income support for the elderly } \\
\text { - } \quad \text { 'bun_s': Unemployment benefit (taken directly } \\
\text { from input data) } \\
\text { - } \quad \text { 'byr_s': Early retirement benefit (taken directly } \\
\text { from input data) }\end{array}$ \\
\hline Estonia & - $\quad$ 'bunnc_s': Unemployment assistance & - $\quad$ 'bchba_s': Birth grant & \\
\hline \multicolumn{4}{|c|}{ 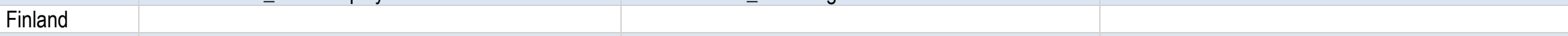 } \\
\hline France & & - 'bchba_s': Birth grant & $\begin{array}{l}\text { - } \quad \text { 'bsuwd_s': Means-tested benefit for widows/ } \\
\text { widowers (taken directly from input data) }\end{array}$ \\
\hline Germany & $\begin{array}{l}\text { - } \quad \text { 'bunct_s': Unemployment benefit (taken } \\
\text { directly from input data) } \\
\text { - } \quad \text { 'pdiac_s': Long-term care benefits from } \\
\text { statutory accident insurance }\end{array}$ & - 'bhl_s': Sickness benefit & \\
\hline Greece & - ' 'bunnc_s': Unemployment assistance & & $\begin{array}{l}\text { - } \quad \text { 'tinwh_s': Withholding tax on benefits } \\
\text { - } \quad \text { 'bched_s': Income support to families with } \\
\text { children in compulsory education (for SILC } \\
\text { taken from input data, no such information in } \\
\text { HFCS) }\end{array}$ \\
\hline Hungary & & - ' 'bmanc_s': Maternity grant & $\begin{array}{l}\text { - } \quad \text { 'bfaot_s': Other family benefit (for SILC } \\
\text { included in input data, no such information in } \\
\text { HFCS) }\end{array}$ \\
\hline Ireland & $\begin{array}{l}\text { - } \quad \text { 'bma_s': Maternity benefit } \\
\text { - } \quad \text { 'bsa00_s': Basic supplementary welfare } \\
\text { allowance } \\
\text { - } \quad \text { 'bhl_s': Injury benefit }\end{array}$ & $\begin{array}{l}\text { - } \quad \text { 'tsceepb_s': Public sector pension related } \\
\text { deduction }\end{array}$ & \\
\hline
\end{tabular}




\begin{tabular}{|c|c|c|c|}
\hline & $\begin{array}{ll}\text { - } & \text { 'bdict_s': Illness benefit } \\
\text { - } & \text { 'bdinc_s': Disability allowance } \\
\text { - } & \text { 'bunnc_s': Jobseeker allowance } \\
\text { - } & \text { 'tpceepi_s': Superannuation employee social } \\
& \text { insurance contributions (Compulsory pension } \\
& \text { contribution) }\end{array}$ & & \\
\hline Italy & - 'tinsv_s': Tax on arrears and severance pay & - 'bfacc_s': Mother bonus & \\
\hline Luxembourg & $\begin{array}{l}\text { - } \quad \text { 'bunss_s': Unemployment benefit (taken } \\
\text { directly from input data) }\end{array}$ & & $\begin{array}{l}\text { - } \quad \text { 'bched04_s': Education allowance (taken from } \\
\text { input data for SILC, no such information in } \\
\text { HFCS, policy no longer exists in 2017) } \\
\text { - } \quad \text { 'bmals_s': Maternity allowance (taken from } \\
\text { input data for SILC, no such information in } \\
\text { HFCS, policy no longer exists in 2017) }\end{array}$ \\
\hline Poland & $\begin{array}{ll}\text { - } & \text { 'bchba01_s': Parental allowance } \\
\text { - } & \text { 'bho_s': Housing benefit } \\
\text { - } & \text { 'bchlp00_s': Supplement for lone parent } \\
\text { - } & \text { 'bcrdi_s': Nursing allowance } \\
\text { - } & \text { 'bsatm_s': Temporary social assistance } \\
\text { - } & \text { 'tag_s': Agricultural tax } \\
- & \text { 'tfrhl_s': Health contribution farmers } \\
\text { - } & \text { 'tscfr_s': Social insurance contribution farmers } \\
\text { - } & \text { 'tscmaee_s': Social insurance contribution } \\
& \text { maternity leave recipients } \\
\text { - } & \text { 'tscmaer_s': Social insurance contribution } \\
& \text { employers of maternity leave recipients }\end{array}$ & - $\quad$ 'bchba_s': Supplement for child birth & \\
\hline Portugal & - $\quad$ 'bunnc_s': Unemployment assistance & & $\begin{array}{l}\text { - } \quad \text { 'poact_s': Contributory old-age pension (taken } \\
\text { directly from input data) }\end{array}$ \\
\hline Slovakia & & - 'bchba_s': Birth grant & \\
\hline Slovenia & $\begin{array}{ll}\text { - } & \text { 'bmact_s': Maternity benefit } \\
\text { - } & \text { 'bmanc_s': Parental allowance }\end{array}$ & - ' 'bchba_s': Birth grant & \\
\hline Spain & $\begin{array}{ll}\text { - } & \text { 'bchucrg_s': Regional universal child benefit } \\
\text { - } & \text { 'bchbaucrg_s': Regional universal birth or } \\
& \text { adoption benefit } \\
\text { - } & \text { 'bchbamtrg_s': Regional means-tested birth or } \\
& \text { adoption benefit }\end{array}$ & $\begin{array}{l}\text { - } \quad \text { 'bchbamtna_s': National means-tested birth or } \\
\text { adoption benefit } \\
\text { - } \quad \text { 'bchbaucna02_s': National multiple birth or } \\
\text { adoption benefit }\end{array}$ & $\begin{array}{l}\text { - } \quad \text { 'bunct02_s': Unemployment benefit for self- } \\
\text { employed (included in bunct) } \\
\text { - } \quad \text { bunmt_s': Temporary unemployment } \\
\text { protection program (included in bunnc_s for } \\
\text { SILC, bunct for HFCS) }\end{array}$ \\
\hline
\end{tabular}


'bchlgurcg_s': Regional universal large family benefit

- 'bchlgmtrg_s': Regional means-tested large family benefit

- $\quad$ 'bchmtrg_s': Regional means-tested child benefit

- 'bunct s': Unemployment benefit (taken directly from input data)

- 'bunnc_s': Unemployment assistance

- 'psuwdcm_s': Contributory widow pension complement

Source: Boone et al. (2019)

Table A. 2. Overview of the new wealth-tax policies simulated in EUROMOD - 2017

\begin{tabular}{|c|c|c|c|c|c|c|}
\hline & Real property tax & Real property transfer tax & Inheritance tax & Gift tax & General net wealth tax & Specific net wealth tax \\
\hline Austria & ES & ES & $\mathrm{N}^{1}$ & $\mathrm{~N}^{1}$ & $\mathrm{~N}$ & $\mathrm{~N}$ \\
\hline Belgium & ES & ES & ES & ES & $\mathrm{N}$ & $\mathrm{N}$ \\
\hline Estonia & ES & $\mathrm{N}$ & $\mathrm{N}$ & $\mathrm{N}$ & $\mathrm{N}$ & $\mathrm{N}$ \\
\hline Finland & ES & ENS & ENS & ENS & $\mathrm{N}$ & $\mathrm{N}$ \\
\hline France & ES & ES & ES & ES & ES & $\mathrm{N}$ \\
\hline Germany & ES & ES & ES & ES & $\mathrm{N}$ & $\mathrm{N}$ \\
\hline Greece & ES & ES & ES & ES & $\mathrm{N}$ & $\mathrm{N}$ \\
\hline Hungary & ENS & ES & ES & ES & $\mathrm{N}$ & $\mathrm{N}$ \\
\hline Ireland & ES & ES & ES & ES & $\mathrm{N}$ & $\mathrm{N}$ \\
\hline Italy & ES & ES & ES & ES & $\mathrm{N}$ & ES \\
\hline Luxembourg & ES & ES & ES & ES & $\mathrm{N}$ & $\mathrm{N}$ \\
\hline Poland & ES & ES & ES & ES & $\mathrm{N}$ & $\mathrm{N}$ \\
\hline Portugal & ES & ES & $\mathrm{ES}^{3}$ & $\mathrm{ES}^{3}$ & $\mathrm{~N}$ & $\mathrm{~N}$ \\
\hline Slovakia & ES & ENS ${ }^{4}$ & $\mathrm{~N}$ & $\mathrm{~N}$ & $\mathrm{~N}$ & $\mathrm{~N}$ \\
\hline
\end{tabular}


58 | DELSA/ELSA/WD/SEM(2021)4

\begin{tabular}{|c|c|c|c|c|c|c|}
\hline Slovenia & ES & ES & ES & ES & $\mathrm{N}$ & $\mathrm{N}$ \\
\hline Spain & ES & ES & ES & ES & $\mathrm{ES}^{5}$ & $\mathrm{~N}$ \\
\hline
\end{tabular}

Notes: ES= exists \& simulated; ENS= exists \& not simulated; $\mathrm{N}=$ does not exist. ${ }^{1}$ The inheritance \& gift tax was abolished in 2008 . A provision for inheritances and gifts still exists under the real property transfer tax. ${ }^{2}$ Inheritance \& gift tax was abolished in 2000 and thereafter included in the legislation of the real property transfer tax. ${ }^{3}$ Inheritance \& gift tax was abolished in 2004 and thereafter included in the duty. ${ }^{4}$ In Slovakia there is a real property transfer tax provision. We are not able to simulate this provision since it requires too specific information. However, the budgetary impact of this tax is very limited. ${ }^{5}$ The general net wealth tax was abolished in Spain between 2008 and 2011 and was reintroduced thereafter.

Source: Boone et al. (2019) 
Annex B: The redistributive effects relative to market income

Figure B 1. The redistributive effects relative to market income, overall population - 2017
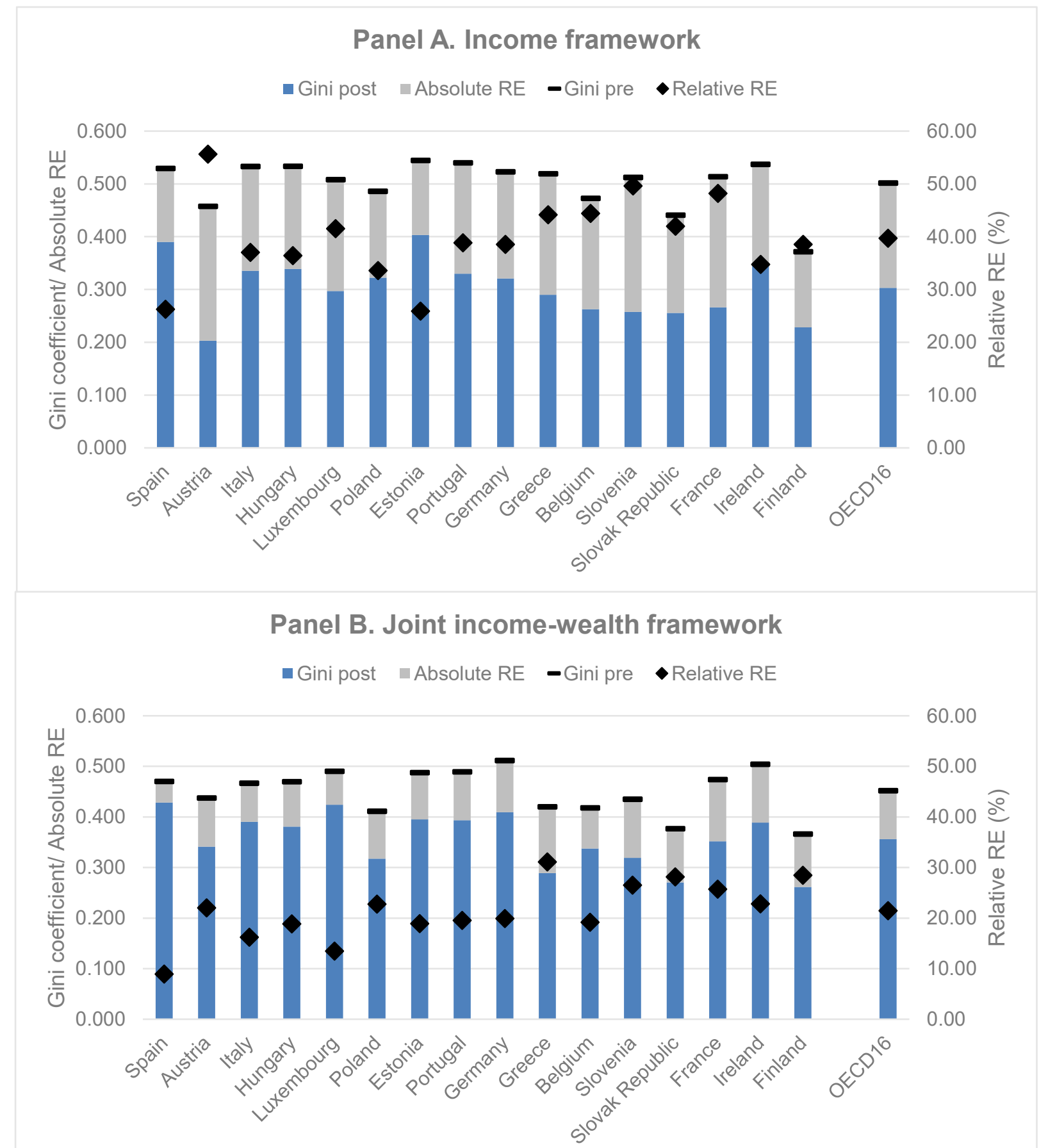

Notes: INC= income framework, INC-NW=joint income-annuitised net wealth framework, RE=redistributive effect. Gini post refers to the Gini coefficient after redistribution, which is the Gini of disposable income in the income framework and the Gini of disposable income plus net annuitised net wealth in the joint income-wealth framework. Gini pre refers to the Gini coefficient before redistribution, which is in this figure the Gini of market income in the income framework and the Gini of market income plus gross annuitised net wealth in the joint income-wealth framework. Countries are ranked in ascending order of the relative redistributive effect in the joint income-wealth framework for the total population.

Source: Authors' calculations based on HFCS wave 2 and EUROMOD. 
Figure B 2. The redistributive effects for the non-elderly, relative to market income - 2017
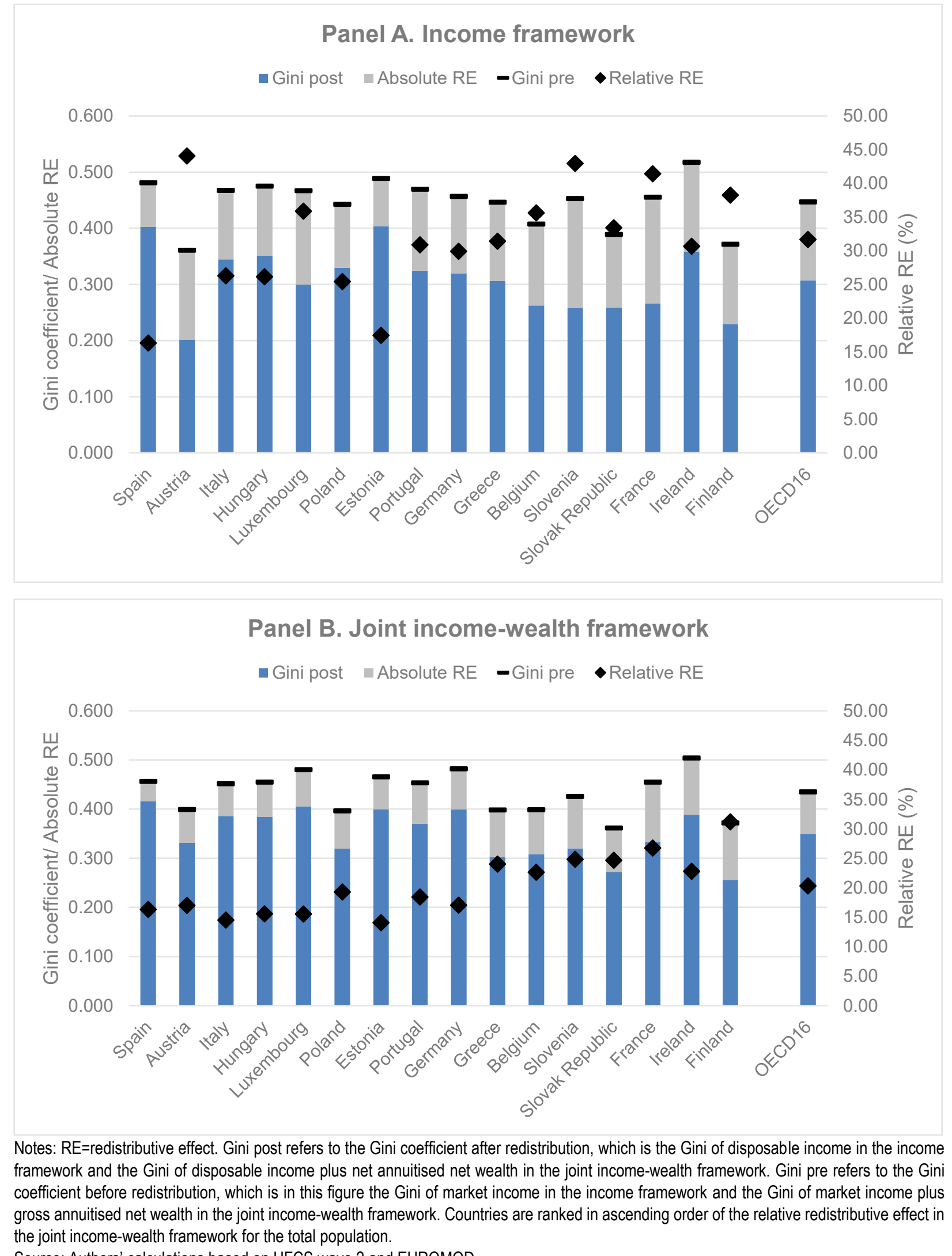

Source: Authors' calculations based on HFCS wave 2 and EUROMOD. 
Figure B 3. The redistributive effects for the elderly, relative to market income - 2017
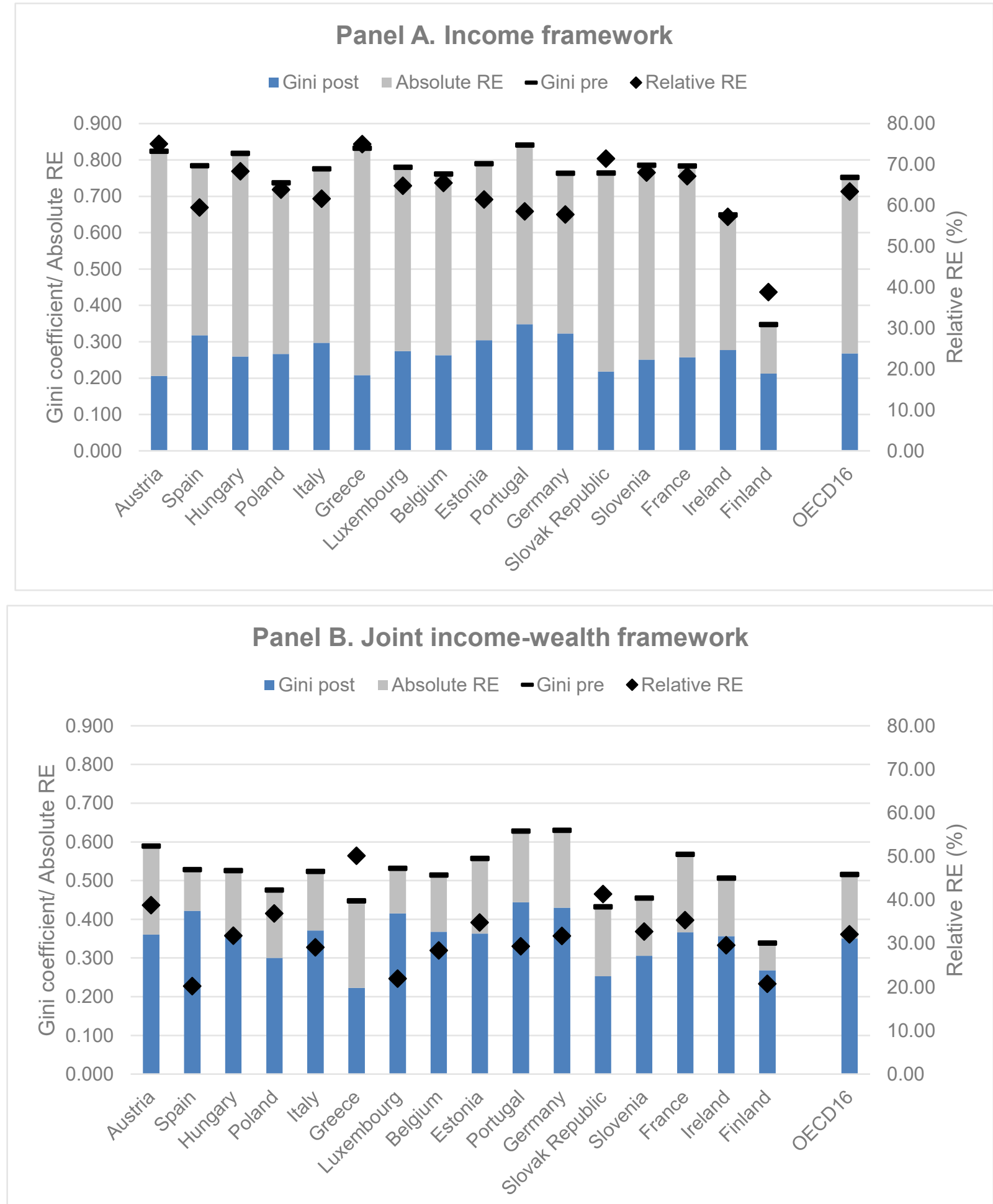

Notes: RE=redistributive effect. Gini post refers to the Gini coefficient after redistribution, which is the Gini of disposable income in the income framework and the Gini of disposable income plus net annuitised net wealth in the joint income-wealth framework. Gini pre refers to the Gini coefficient before redistribution, which is in this figure the Gini of market income in the income framework and the Gini of market income plus gross annuitised net wealth in the joint income-wealth framework. Countries are ranked in ascending order of the relative redistributive effect in the joint income-wealth framework for the total population.

Source: Authors' calculations based on HFCS wave 2 and EUROMOD. 